\title{
Dynamic processes controlling foreland development - the role of mechanical (de)coupling of orogenic wedges and forelands
}

\author{
P. A. Ziegler ${ }^{1}$, G. Bertotti ${ }^{2}$, and S. Cloetingh ${ }^{2}$ \\ ${ }^{1}$ Geological-Palaeontological Institute, University of Basel, Bernoullistr. 32, 4065 Basel, Switzerland \\ ${ }^{2}$ Department of Sedimentary Geology, Faculty of Earth Sciences, Free University, de Boelelaan 1085, 1081 HV Amsterdam, \\ The Netherlands
}

Received: 15 February 2001 - Revised: 4 September 2001 - Accepted: 12 October 2001

\begin{abstract}
Depending on the polarity of the subduction system controlling the evolution of an orogenic wedge, we distinguish between pro-wedge (fore-arc, foreland) and retrowedge (retro-arc, hinterland) forelands. Flexural foreland basins and/or intraplate compressional structures can develop in retro-wedge domains of Andean-type and in pro- and retro-wedge domains of Himalayan-type orogens.

Whereas the subsidence of retro-wedge foreland basins is exclusively controlled by the topographic load exerted by the orogenic wedge on the foreland lithosphere, the additional load of the subducted lithospheric slab contributes towards the subsidence of pro-wedge foreland basins. Flexural forebulges develop only if the orogenic wedge and the foreland lithosphere are mechanically decoupled at lithospheric levels.
\end{abstract}

Under conditions of mechanical coupling between an orogenic wedge and its foreland at crustal and/or mantlelithospheric levels, compressional stresses are transmitted into the latter, inducing reactivation of pre-existing crustal discontinuities and broad crustal and lithosphere scale folding at distances up to $1700 \mathrm{~km}$ from the collision front. Such stresses can accentuate potential pre-existing flexural forebulges or impede their development. Depending on the thickness and rheological structure of the crust and its sedimentary cover, thick- and/or thin-skinned thrusts can propagate far into forelands, either disrupting pre-existing flexural foreland basins or impeding their development.

Collision-related compressional stresses can be transmitted into pro-wedge forelands during 1) initiation of subduction zones, 2) periods of subduction impediment caused by the arrival of more buoyant crust at a subduction zone, 3) initial collision of an orogenic wedge with a passive margin, and 4) post-collisional over-thickening and uplift of an orogenic wedge and the development of a mantle-back-stop.

Development of intraplate compressional/transpressional structures in forelands is indicative for the build-up of collision-related compressional stresses, and thus for strong

Correspondence to: P. A. Ziegler (fax +41-061-421.55.35) mechanical coupling of a foreland with the associated orogenic wedge, either at crustal and/or mantle-lithospheric levels. The absence of syn-orogenic intraplate compressional structures suggests that the respective orogenic wedge and its foreland(s) were mechanically decoupled. The level of mechanical coupling between an orogenic wedge and its foreland is temporally and spatially variable.

Mechanical coupling and uncoupling of orogenic wedges and their forelands probably depends on the geometry and frictional shear strength of their common boundary zone. Subduction resistance of the foreland, as well as the buildup of high fluid pressures in subducted sediments, presumably play an important role. Pro-wedge continental crust and mantle-lithosphere can be subducted to depths of 100 $150 \mathrm{~km}$ at which it can no longer support the weight of the attached oceanic slab and fails. Slab-detachment results in uplift of the orogen, mantle back-stop development and the transmission of major collision-related stresses into the forelands.

The tectono-stratigraphic record of forelands monitors the evolution of collision-related stress fields, the level of mechanical coupling between an orogen and its foreland(s), and thus contributes to dating orogenic activity affecting a plate margin. These concepts are discussed on the base of the evolution of selected forelands of Palaeozoic and younger orogens in Europe, North Africa, Arabia and North America.

\section{Introduction}

Most Phanerozoic orogens, both of the Andean-type (continent-ocean collision) and the Himalayan-type (continent-continent collision), are or were at one time associated with more or less well developed flexural foreland basins. Some of these basins were destroyed either during late syn-orogenic phases or during post-orogenic times. Moreover, the evolution of many orogens was associated with the development of compressional intraplate structures in their distal forelands, ranging from upthrusting of 
basement blocks and inversion of tensional basins to broad lithospheric folding (Ziegler 1990; Cobbold et al., 1993; Ziegler et al., 1995, 1998; Cloetingh et al., 1999).

The width of preserved flexural foreland basins varies considerably and ranges from 10-50 km (e.g. Lower Austrian Molasse basin: Zimmer and Wessely, 1996) to $500 \mathrm{~km}$ (Central Appalachians) and even up to $800-1000 \mathrm{~km}$ (Alberta Basin: Bally, 1989; Ural Basin: Fokin et al., 2001). However, some orogenic belts are not associated with well developed flexural foreland basins. Although in some cases such basins had developed during early syn-orogenic phases, they were subsequently disrupted during syn-orogenic phases by upthrusting of basement blocks (e.g. Rocky Mtns: Oldow et al., 1989) and/or by inversion of pre-existing extensional basins in the foreland (e.g. Atlas troughs: Frizon de Lamotte et al., 2000; West Alpine foreland: Roure and Colletta, 1996), or were eroded due to regional post-orogenic uplift (e.g. Caledonides of Sweden and Norway: Ziegler, 1989, 1990). Alternatively, syn-orogenic partial to total destruction of flexural foreland basins can also be caused by the propagation of thin- and/or thick-skinned thrusts far into the foreland (e.g. Dinarides: Pamic et al., 1998; Appalachians: Rast, 1998; Mackenzie Mtns.: Oldow et al., 1989; Southern Alps: Ziegler et al., 1996), or by the emplacement of major allochthonous nappes (Eastern Alps: Zimmer and Wessely, 1996). The frequently observed post-orogenic uplift of foreland basins can be attributed to un-flexing of the lithosphere in response to such processes as detachment of the subducted lithospheric slab (Fleitout and Froidevaux, 1982; Bott, 1990, 1993; Andeweg and Cloetingh, 1998), retrograde metamorphism of the orogenic crustal roots involving in the presence of fluids the transformation of eclogite to less dense granulite (Le Pichon et al., 1997; Bousquet et al., 1997; Straume and Austrheim, 1999), and erosional and/or tensional tectonic unroofing of the orogen (Stockmal et al., 1986; Sanders et al., 1999).

In this paper we address dynamic processes which control the development and destruction of flexural foreland basins during the evolution of orogenic wedges. Special emphasis is given to evidence for associated intraplate compressional foreland deformation, reflecting strong mechanical coupling between the evolving orogenic wedge and its foreland(s). In this respect it should be kept in mind that mechanical coupling of the orogenic wedge with its foreland involves the transmission of compressional stresses from the collision zone into the latter, either at supra-crustal and/or crustal and/or mantle-lithospheric levels. In this context, rheologically weak layers within or at the base of the supra-crustal sedimentary sequence, within or at the base of the crust and at the base of the mechanical lithosphere can act as stress guides, controlling the deformation mode of the foreland.

In the first part of this paper we summarize dynamic processes which control the development of foreland basins and address the flexural forebulge phenomenon. In the next part we review the evolution of selected Palaeozoic and younger orogens and their forelands in Europe, North Africa, Arabia and North America. In the third part we assess on the
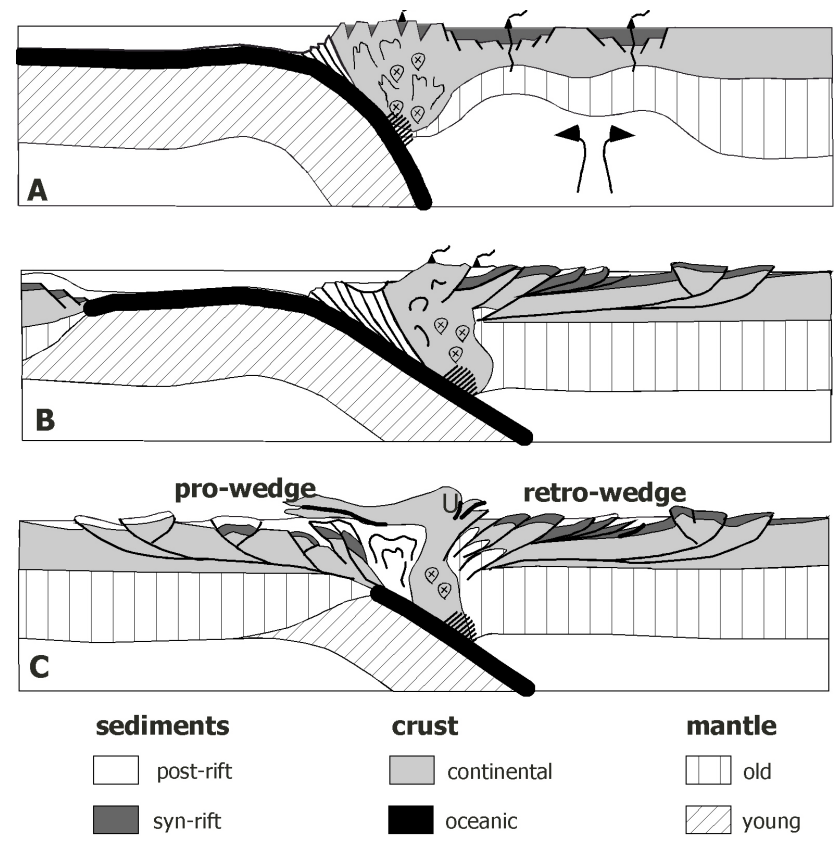

Fig. 1. Conceptual model illustrating (a) back-arc extension, (b) retro-wedge (back-arc) foreland compression, and (c) collisional retro-wedge (back-arc) and pro-wedge (fore-arc) foreland compression (after Ziegler et al., 1998).

base of the discussed examples the question of mechanical (un)coupling of orogenic wedges and their forelands and address the interplay between stress and rheology. Finally, we draw conclusions on the problem at hand.

\section{Types of Flexural Foreland Basins}

Depending on the polarity of the subduction system which controls the evolution of an orogenic wedge, we distinguish between flexural pro-wedge (fore-arc, foreland) foreland basins and retro-wedge (retro-arc, hinterland) foreland basins (Fig. 1; Ziegler, 1989, 1990; Willet et al., 1993; Johnson and Beaumont, 1995; Bertotti et al., 1998). Pro-wedge flexural foreland basins are associated with B-subduction zones, along which oceanic lithosphere was consumed prior to the collision of the orogenic wedge with its continental foreland and the subsequent subduction of continental lithosphere. By contrast, flexural retro-wedge foreland basins are associated with A-subduction zones along which generally only continental lithosphere was consumed (Bally and Snelson, 1980); exceptions involve the closure of limited oceanic back-arc basins prior to the onset of continental lithosphere subduction (e.g. Devonian Rhenohercynian Basin of the Variscan Orogen and Late Carboniferous Havallah Basin of the North American Cordillera; Ziegler, 1989, 1990; Ziegler et al., 1995, 1998).

A fundamental difference between these two types of foreland basins is that the subsidence of retro-wedge basins is generally exclusively controlled by the topographic (tec- 


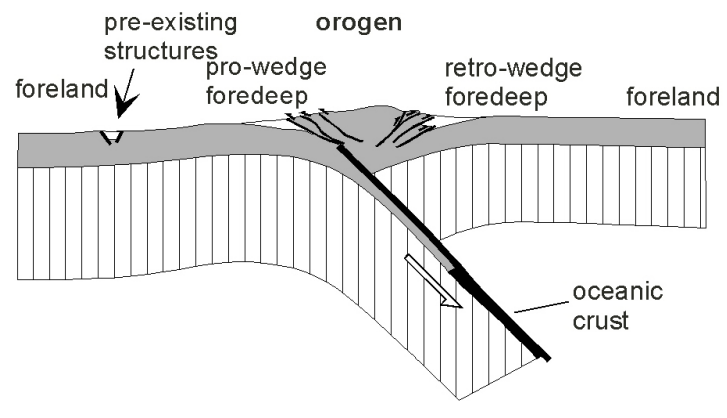

continental crust

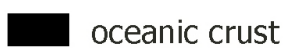



Fig. 2. Conceptual model illustrating forces controlling the subsidence of retro- and pro-wedge foreland basins and showing zone of potential mechanical coupling between the upper and lower plate.

tonic) load of the orogenic wedge, whereas the subsidence of pro-wedge foreland basins is governed by a combination of the topographic load of the orogenic wedge and the weight of the subducted lithospheric slab (Fig. 2; Stockmal and Beaumont, 1987; Royden, 1993; Andeweg and Cloetingh, 1998), at least up to the moment of detachment of such a slab from the lithosphere. The magnitude of the load exerted by a subducted lithospheric slab on a pro-wedge foreland depends on the slab composition (oceanic, continental), as well as on its length and dip, which in turn depend on the duration of subduction, the rate of plate convergence and possibly on the direction of general mantle flow (Doglioni, 1993; Doglioni et al., 1999). Therefore, a much greater load is exerted on pro-wedge forelands which are associated with long-standing, deep reaching oceanic subduction zones (e.g. Apennines: Doglioni, 1993; Urals: Fokin et al., 2001) than on those which are associated with short duration continental subduction (e.g. Pyrenees: Gaspar-Escribano et al., 2001).

\section{Flexural Forebulge Phenomenon}

Most arc-trench systems, along which normal oceanic lithosphere is actively subducted, are characterized by a more or less well expressed flexural forebulge that parallels the distal trench margin (Fig. 3). The wavelength (up to $200 \mathrm{~km}$ ) and amplitude (up to $500 \mathrm{~m}$ ) of such forebulges is controlled by the age-dependent thickness and elastic strength of the oceanic lithosphere and the subduction rate-dependent dip angle of the Benioff zone (Turcotte et al., 1978; Bodine et al., 1981; Bott, 1982).

Along outer trench slopes and within trenches which are associated with such a forebulge, and depending on the flexure intensity, the oceanic crust can be affected by an array of trench-parallel extensional faults (for examples see Bally, 1983). Such crustal faults develop in response to bending stresses, whereas the lower parts of the lithosphere are in compression. At subduction zones, sediments overlying the oceanic crust are partly scraped off and incorporated into accretionary wedges; however, the bulk of these sediments is

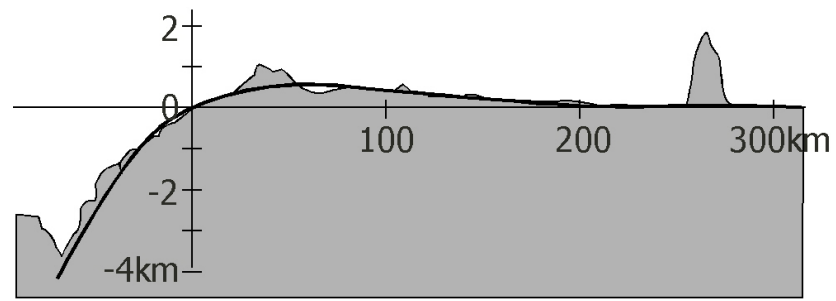

Fig. 3. Flexural bulge associated with Mariana trench with best fit flexural plate (thick line) (after Turcotte et al., 1978).

subducted (Von Huene and Scholl, 1991, 1993). Sediment subduction, involving the build-up of high pore-pressures (Von Huene and Lee, 1982), can account for mechanical decoupling of the orogenic wedge and the oceanic foreland plate. Under such conditions, the subducting plate is exclusively subjected to bending stresses and slab pull forces (which can constructively interfere with ridge-push force), thus allowing for the development of a flexural forebulge.

Other trench systems, such as those of Sumatra and Java, lack a flexural forebulge. This is attributed to compressional and tensional stress fields within the subducting oceanic and continental Indo-Australian plate that developed in response to its laterally variable collisional coupling with Asia (Cloetingh and Wortel, 1986). In this context, it must be realized that subduction processes can be impeded when e.g. an oceanic plateau, a transform ridge or a continent collides with an arc-trench system (Mueller and Phillips, 1991; Cloos, 1993). Unless such a subduction obstacle is sheared off and incorporated into the accretionary wedge (Lallemand et al., 1989; Von Huene et al., 1997), tangential compressional stresses build up within the subducting plate, potentially causing its imbrication (e.g. Southwest Japan Nankai Trough, Izu-Bonin and Zenisu ridges: Lallemant et al., 1989; Lallemand et al., 1992). Under such conditions, the subducting plate is no longer exclusively subjected to bending, slabpull and ridge-push stresses. Compressional stresses, building up in response to increasing mechanical coupling be- 
tween the orogenic wedge and the subducting foreland plate, interfere with the development of a purely flexural forebulge and may ultimately lead to subduction progradation to the distal margin of the subduction obstacle (Ziegler et al., 1998).

The concept of flexural down-bending of continental lithosphere in response to tectonic and topographic loading by orogenic wedges, controlling the development of foreland basins, was postulated by Price (1973) and subsequently quantitatively modelled by Beaumont (1981), Jordan (1981), Beaumont et al. (1982), Karner and Watts (1983) and others (see Stockmal et al., 1986). The width and depth of a flexural foreland basin depends on

(i) the effective elastic thickness $\left(\mathrm{T}_{\mathrm{e}}\right)$ of the continental lithosphere (thickness, composition; McNutt et al., 1988; Burov and Diamet, 1995),

(ii) the level of horizontal stresses (Cloetingh and Burov, 1995),

(iii) the magnitude of the loads imposed on the foreland by the orogenic wedge and the subducted lithospheric slab (Stockmal et al., 1986; Royden, 1993),

(iv) the convergence rate and direction (orthogonal, oblique) and

(v) the dip-angle of the subducted lithospheric slab (Doglioni, 1993).

Lateral changes in the geometry of a foreland basin are related to variations in the mechanical properties of the loaded plate, resulting from previous tectonic events such as rifting and passive margin formation, as well as to variations in the loads imposed on it (Waschbusch and Royden, 1992; Millan et al., 1995).

Similar to oceanic trenches, and depending on the wavelength and amplitude of the flexural deflection of the continental lithosphere, the crust of pro- and retro-wedge foreland basins can be affected by a system of basin-parallel, generally small-scale normal faults that develop in response to bending stresses (e.g. pro-wedge Alpine foreland basin of Germany and Austria: Roeder and Bachmann, 1986; Nachtmann and Wagner, 1987; retro-wedge Taconic foreland basin of Quebec: Dykstra and Longman, 1995; retro-wedge Arkoma foreland basin of Ouachita Mtns.: Arbenz, 1989; retro-wedge Patagonian Cordillera foreland basin: Diraison et al., 2000).

By analogy with forebulges associated with oceanic trenches, and assuming that the underthrusted continental foreland lithosphere has a sufficiently large $T_{e}$ to support the load of the evolving orogenic wedge, Beaumont (1981) predicted that flexural forebulges would develop along the distal margins of foreland basins (Beaumont et al., 1982, Stockmal et al., 1996). In this respect, the episodic development of unconformities across relatively low-relief arches along the distal margin of the Appalachian foreland basin was attributed to the development of a flexural forebulge in response to thrust-loading of the foreland lithosphere and its subsequent visco-elastic relaxation (Quinlan and Beaumont, 1984; Tankard, 1986; Stockmal and Beaumont, 1987; Beaumont et al., 1987).

The concept of forebulge development was widely adopted and almost indiscriminately applied to a number of examples. However, these warrant critical review in the face of contemporaneous, partly far-field intraplate compressional deformations, involving fault reactivation, basin inversion and broad lithospheric folding that must be attributed to strong mechanical coupling of the respective orogenic wedge with its continental foreland at crustal and/or mantlelithospheric levels (Ziegler et al., 1995, 1998).

As with oceanic lithosphere, development of purely flexural forebulges in continental lithosphere requires that the orogenic wedge and its foreland are mechanically decoupled at crustal and mantle-lithospheric levels so that no major tangential shear stresses can be transmitted into the latter. In this respect, it must be realized that continental lithosphere can present considerable subduction resistance, particularly during its initial collision with an arc-trench system (Ziegler et al., 1998). During over-thickening of an orogenic wedge, and particularly during continent-continent collision and the development of a mantle back-stop, following detachment of the subducted lithospheric slab, major compressional stresses can apparently be projected into the proand retro-wedge forelands of an orogen, both at crustal and mantle-lithospheric levels (Ziegler and Roure, 1996; Ziegler et al., 1995, 1998). This concept is borne out by the occurrence of intraplate compressional structures in the forelands of many orogenic belts, as well as by the involvement of foreland crustal slices in the architecture of orogenic wedges, forming external crystalline massifs (Ziegler et al., 1995, 1996). Collision-related compressional stresses can interfere with the development of a purely flexural forebulge by accentuating its amplitude and by narrowing and deepening of the associated foreland basin in response to crustal and/or lithospheric folding (Cloetingh, 1988; Peper et al., 1992; Cloetingh et al., 1999; Zhang and Bott, 2000). If such stresses exceed the yield strength of the foreland lithosphere, resulting arches can attain amplitudes of 2-3 km and more (e.g. Vosges-Black Forest arch), particularly if the lithosphere is thermally weakened by magmatic activity (Cloetingh et al., 1989).

\section{Evolution of selected Orogenic Wedges and their Forelands}

Examples discussed in this chapter were carefully selected from a very broad data base in an effort to illustrate the spectrum of variations in the evolution of foreland basins. Special attention will be given to the spatial and temporal development of intraplate compressional structures in the forelands of orogenic wedges, as well as to the tectonic setting of features that have been attributed to the development of flexural forebulges. 


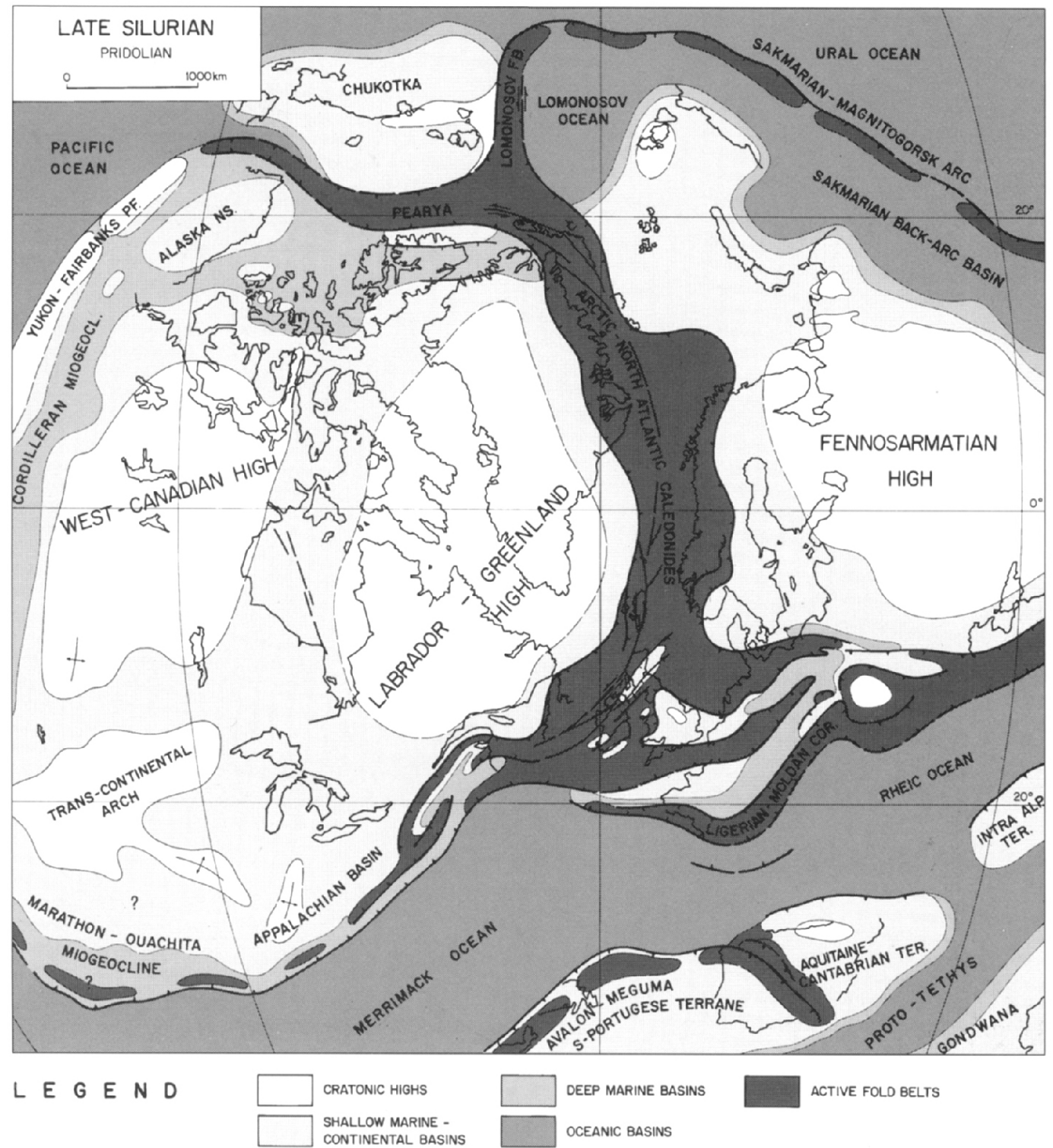

Fig. 4. Late Silurian (Pridolian) tectonic framework of Laurussia (after Ziegler, 1989). Abbreviations: COR = cordillera, NS = Alaska North Slope, $\mathrm{PF}=$ platform, TER $=$ terrane.

\subsection{Arctic-North Atlantic Caledonides and their Forelands}

Siluro-Ordovician evolution of the Arctic-North Atlantic Caledonides involved the convergence of LaurentiaGreenland and Baltica, of the Gondwana derived composite Avalonia continental terrane with Baltica and Laurentia, and of continental Arctica with the northern margin of Laurentia-Greenland (Fig. 4; Ziegler, 1989, 1990; Pharaoh, 1999). This resulted in closure of the Iapetus, Tornquist and Arctic oceans that had separated Laurentia-Greenland and Baltica, Avalonia and Baltica and Laurentia-Greenland and Arctica, respectively (Torsvik, 1998).

By mid-Silurian times, the Iapetus Ocean was closed by westward subduction beneath Greenland. With this, thrustloaded subsidence of the Baltica pro-wedge foreland com- menced and persisted until the Early Devonian termination of the Scandian orogenic cycle during which the crust of Baltica was imbricated into a system of major basementcored nappes (Gee, 1978; Gee et al., 1985; Stephens and Gee, 1985; Torsvik, 1998). Under such a scenario, Greenland formed the retro-wedge foreland of the Arctic-North Atlantic Caledonides. However, the foreland and external thrust front of the Greenland Caledonides are concealed by glaciers (Andersen and Hartz, 1998).

Closure of the Tornquist Ocean by southward subduction beneath Avalonia resulted in Late Ordovician-Early Silurian collision of East-Avalonia with the pro-wedge Baltica foreland. This was followed by the development of a broad flexural foreland basin, parts of which are still preserved in the down-faulted Oslo Graben, in the Baltic Sea and in northeast- 


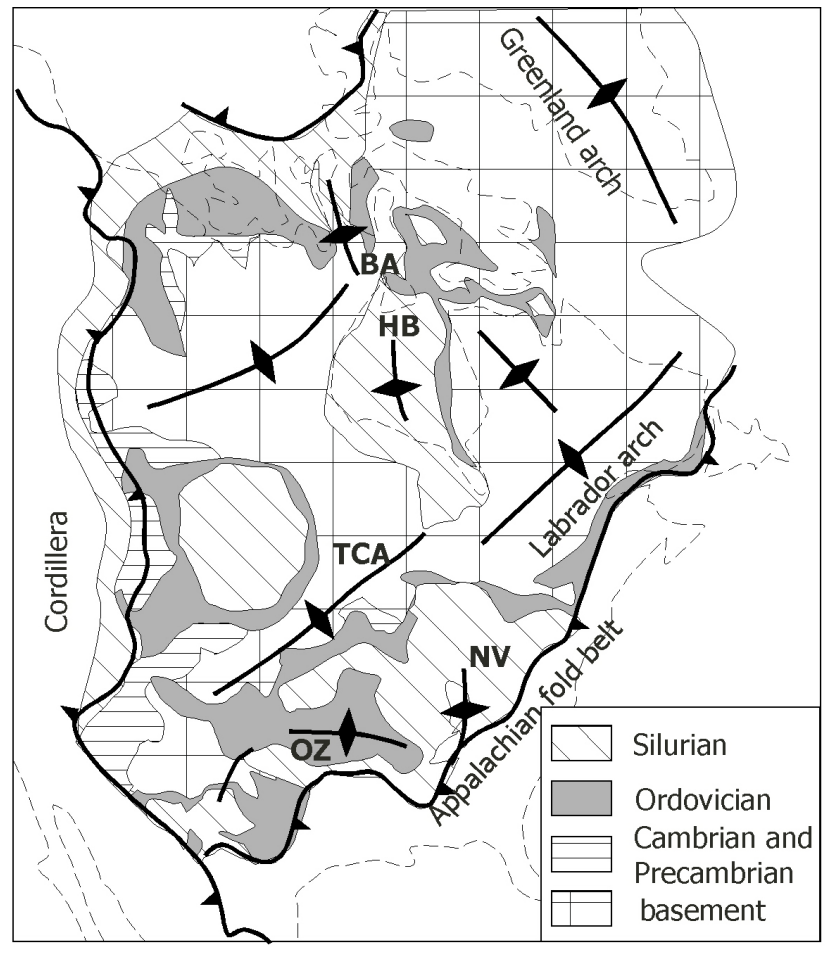

Fig. 5. Geological map of North America with Devonian and younger strata removed, showing subcrop pattern of Lower Palaeozoic series at the base of the Kaskaskia (Devonian-Early Carboniferous) sequence (after Cook and Bally, 1975; Bally, 1989; Ziegler et al., 1995). BA = Boothia Arch, $\mathrm{HB}=$ Hudson Bay, NV = Nashville Dome, $\mathrm{OZ}=$ Ozark Uplift, $\mathrm{TCA}=$ Transcontinental Arch.

ern Poland (Ziegler, 1989, 1990; Pharaoh, 1999; Poprawa et al., 1999).

During the Late Silurian-earliest Devonian, an active arctrench system apparently extended south-westwards from the Caledonides of the British Isles into the area of the Canadian Maritime Provinces and the New England States (Fig. 4) where the Salinian orogenic pulse gave rise to the accumulation of flysch in a complex system of interarc basins. This orogenic pulse may have been associated with the initial docking of the West-Avalonia composite terrane that was finally accreted to North America during the Middle Devonian main Acadian orogeny (Ziegler, 1989; Robinson et al., 1998). Whether during Late Silurian-Early Devonian times an active arc-trench system extended southwards along the entire eastern margin of North America is uncertain.

Geodynamic considerations suggest that evolution of the Himalayan-type Arctic-North Atlantic Caledonides was associated with the development of major flexural pro-wedge and retro-wedge foreland basins (Greiling et al., 1998). However, the only remnants of Caledonian pro-wedge basins are preserved in the Oslo Graben and in the Baltic (North German-Polish Caledonides). Indirect evidence for the development of a retro-wedge foreland basin in northern Greenland is provided by the Late Silurian influx of clastics into the Franklinian Basin in the Inuitian foreland (Ziegler,
1989, 1990).

That indeed a major flexural foreland basin was associated with the Scandinavian Caledonides is suggested by fissiontrack data from southern and central Sweden. These indicate that an at least $2.5 \mathrm{~km}$ thick sedimentary sequence was eroded from their foreland during Late Palaeozoic and Early Mesozoic times (Åke Larson et al., 1999; Cederbom et al., 2000, D. G. Gee personal communication 1996). This is corroborated by the out-building of major Late Permian and Triassic deltaic complexes from the Kola Peninsula into the Barents Sea (Johansen et al., 1992; Nikishin et al., 1996), as well as by the Triassic massive transport of clastics from Scandinavia into the Northwest European Basin (Ziegler, 1990). This erosional phase may be related to large radius arching of the evolving Norwegian-Greenland Sea rift system (Ziegler, 1988).

During the Silurian-earliest Devonian evolution of the Arctic-North Atlantic Caledonides, increasing collisional resistance of the thick lithospheres of Baltica and Laurentia resulted in subduction progradation into the Uralian Ocean and the activation of the intra-oceanic Sakmarian-Magnitogorsk arc-trench systems (Fig. 4) (Ziegler, 1989; Zonenshain et al., 1990). Moreover, increasing collisional coupling between the Caledonian orogenic wedge and its conjugate forelands at crustal and mantle-lithospheric levels is evidenced by profound imbrication of the foreland crust and its involvement in the orogenic wedge. In addition, far field deformation of the Laurentian and East-European cratons occurred at the transition from the Silurian to the Devonian, involving reactivation of pre-existing fracture systems, broad lithospheric folding and the development of a regional unconformity (Ziegler et al., 1995; Nikishin et al., 1996). On the Laurentian Craton, intraplate compressional stresses induced upthrusting of basement blocks in the Hudson Bay and uplift of the Transcontinental, Ozark, Nashville, Labrador, Bell, Peace River-Keewatin arches, resulting in disruption of the formerly regional Ordovician-Silurian carbonate platform (Fig. 5; Cook and Bally, 1975; Bally, 1989; Ziegler et al., 1995). Similarly, the subcrop pattern of pre-Devonian series on the East-European Carton reflects its broad-scale folding and the inversion of some rifted structures in the Mid-Russian aulacogen belt and Baltic Basin (Milanovsky, 1987; Nikishin et al., 1996). Stresses controlling these deformations relaxed with the Early Devonian activation of the Arctic-North Atlantic mega-shear which transects the Caledonides along their axis (Fig. 6). Devonian-Early Carboniferous motions along this shear zone accounted for a sinistral translation of Laurentia-Greenland relative to Baltica and controlled the post-orogenic collapse of the Caledonides (Ziegler, 1989, 1990).

\subsection{Foreland of the Inuitian Orogen}

The Inuitian Orogen developed in response to collision of the continental Arctica block (Chukotka, New Siberian Islands) with the northern margin of the North American Craton. Presumably this involved subduction of an intervening oceanic 


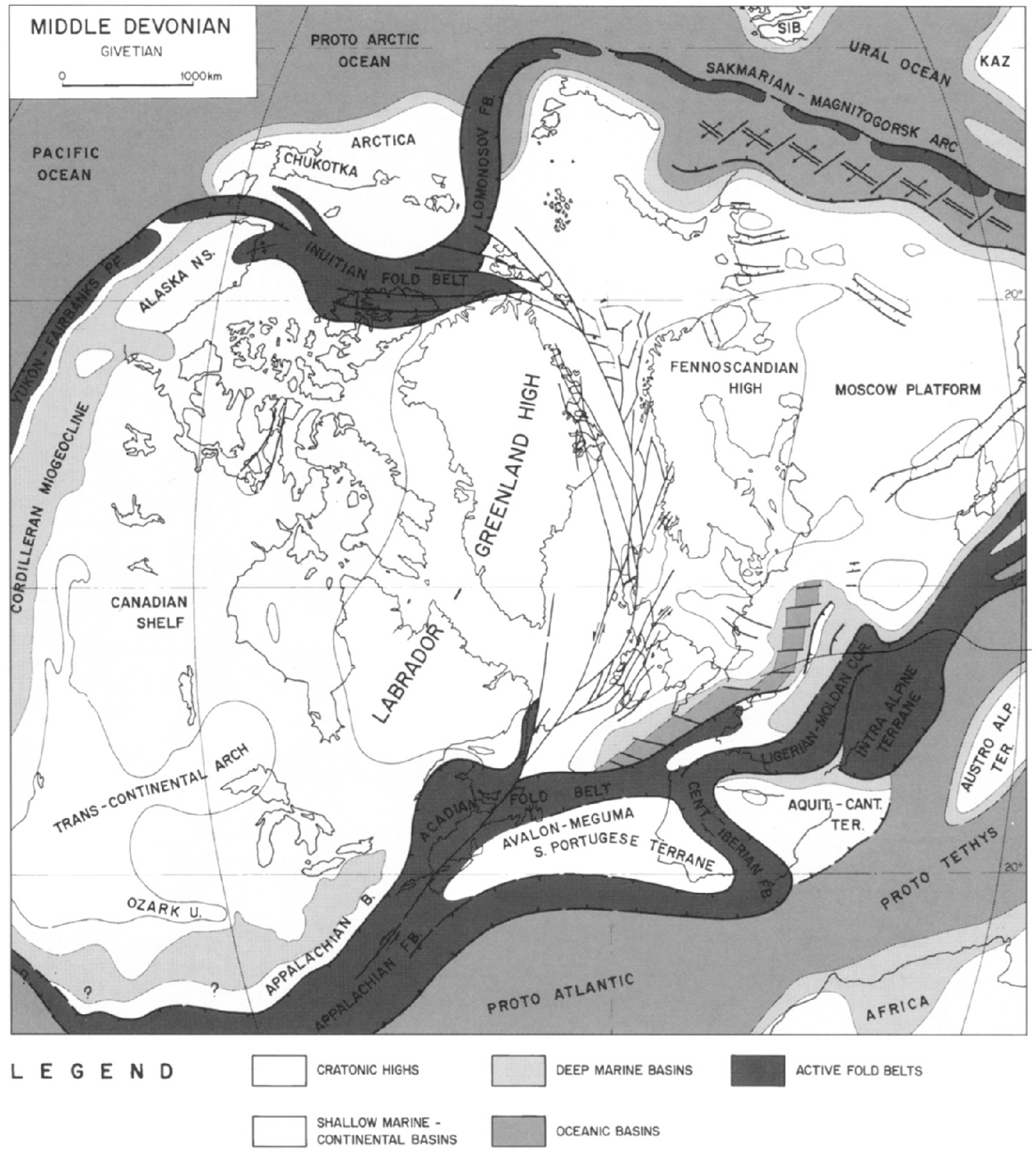

Fig. 6. Middle Devonian (Givetian) tectonic framework of Laurussia (after Ziegler, 1989). Abbreviations: $\mathrm{B}=$ basin, $\mathrm{COR}=\mathrm{cordillera}, \mathrm{FB}=$ fold belt, KAZ = Kazakhstan, NS = Alaska North Slope, $\mathrm{PF}=$ platform, SIB $=$ Siberia, TER $=$ terrane.

basin beneath an Arctica that was fringed to the south by the Pearya arc-trench system (Fig. 4). Collision of Arctica with the Canadian margin probably occurred during the Silurian, as suggested by the late Early Silurian onset of clastic influx from northern sources into the reef fringed Franklinian deeper water (passive margin) basin, and by the Late Silurian uplift of the north-south trending, basement cored and fault bounded Boothia Arch, which transected the southern margin of this basin (Fig. 6). The Inuitian orogeny lasted until early Mississippian times. Commencing in the late Mississippian, this orogen was disrupted by rifting that controlled the subsidence of the Sverdrup Basin (Trettin and Balkwill, 1979; Trettin, 1989; Ziegler, 1969, 1988, 1989).

Sedimentation in the proximal parts of the Franklinian
Basin was dominated until early Eifelian times by the accumulation of thick, orogen-derived turbiditic series, whereas carbonate platforms occupied its distal, southern parts. During the Early Devonian, the Boothia Arch was further accentuated and the Inglefield Arch of south-eastern Ellesmere Island came into evidence (Fig. 7) (Kerr, 1977, 1981; Smith and Okulitch, 1987). By late Eifelian times, the entire basin had shallowed out and had assumed the geometry of a classical flexural foreland basin, in which a huge deltaic complex prograded southwards from the rising orogenic wedge to cover the pre-existing carbonate platform. By this time, the Boothia and Inglefield arches had become inactive. During the Late Devonian, a continental and deltaic clastic wedge prograded apparently even further southwards in an over 


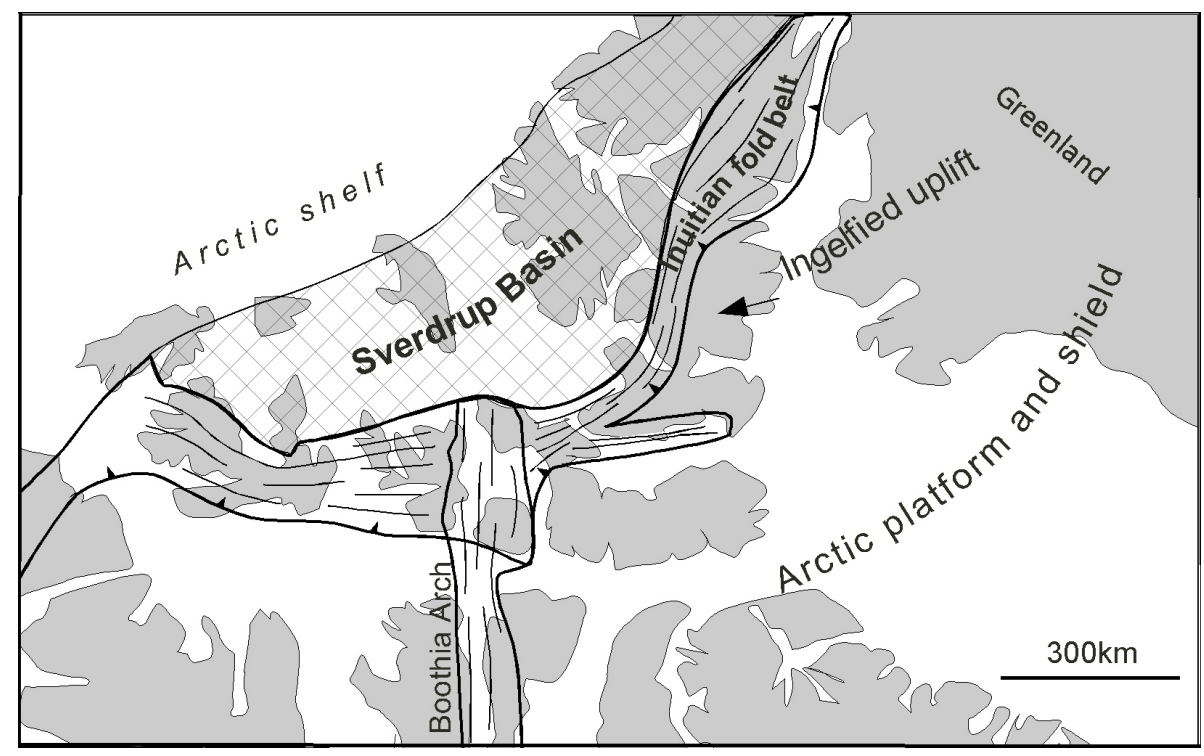

Fig. 7. Schematic tectonic map of Arctic Canada, showing outlines of the thin-skinned Inuitian fold belt, the basement-involving Boothia Arch and the post-orogenic Sverdrup Basin (after Kerr, 1981; Trettin, 1989).

$1000 \mathrm{~km}$ wide foreland basin that was offset to the south by the Canadian carbonate platform. During the end Devonianearly Mississippian terminal phase of the Inuitian orogeny, thin shinned thrust sheets propagated far into this foreland basin, forming the Parry Island fold- and-thrust belt (Fig. 7). At the same time the Boothia Arch was reactivated (Kerr, 1977, 1981; Trettin, 1989; Ziegler, 1988, 1989).

The evolution of the Inuitian Orogen reflects intermittent mechanical coupling between the orogenic wedge and its pro-wedge foreland at crustal levels, inducing upthrusting of major basement blocks in the distal foreland, such as the $800 \mathrm{~km}$ long and $120-180 \mathrm{~km}$ wide north-south trending Boothia Arch (Fig. 7).

\subsection{Forelands of Late Palaeozoic Orogens}

During the Carboniferous and Early Permian suturing of Gondwana and Laurussia along the Variscan and Applalachian-Mauretanides-Ouachita-Marathon orogens (Fig. 8), major retro-wedge foreland basins developed in Western and Central Europe and in the Appalachian domain, while in the Ouachita-Marathon domain syn-orogenic retro-wedge intraplate compression resulted in the development of the Ancestral Rocky Mtns. Either pro-wedge foreland basins did not develop in the African foreland of the Variscan and Mauretanides orogens or they were destroyed during late orogenic phases. During the CarboniferousPermian collision of Kazakhstan and Siberia with the EastEuropean Craton, a major pro-wedge basin developed in the foreland of the southern and central Urals, whereas in the northern Uralian foreland intraplate compression interfered with the development of a classical foreland basin.

\subsubsection{European Variscan Foreland}

The Variscan foreland basin of Europe is superimposed on the northern shelf of the oceanic Rhenohercynian back-arc basin. The latter had opened during the Early Devonian in response to back-arc extension and subsequently underwent a sequence of compressional and extensional phases during Middle Devonian (Fig. 6) and earliest Carboniferous times. By the mid-Visean onset of the main Variscan orogenic cycle, this basin was closed by southward subduction beneath the Mid-German Crystalline High. Following late Visean detachment of the subducted oceanic slab, reflected by a change from I-type to shoshonitic magmatism in the MidGerman Crystalline High (Altherr et al., 1999), compressional stresses were projected into the Rhenohercynian Shelf, causing disruption of its carbonate platform and the development of a regional unconformity. From the early Namurian onwards, this shelf subsided rapidly under the loads of the advancing nappe systems that account for a total of $200 \mathrm{~km}$ of shortening (Oncken et al., 1999). During the Westphalian, the evolving foreland basin reached a maximum width of some $700 \mathrm{~km}$ in the southern North Sea area, whereas in its Irish and Polish sectors it was only some $200 \mathrm{~km}$ wide (Figs. 8 and 9) (Ziegler, 1990).

During the Late Westphalian, increasing collisional coupling between the Variscan Orogen and its foreland at crustal and mantle-lithospheric levels is evidenced by upwarping of the Brabant Massif, upthrusting of the Malopolski Massif and the inversion of Late Devonian-Namurian rifts in the British Isles (Fig. 9).

Upon end-Westphalian termination of shortening in the Rhenohercynian thrust belt, the Variscan Orogen and its northern foreland were deeply disrupted during the Stephanian and Early Permian by a conjugate system of wrench 




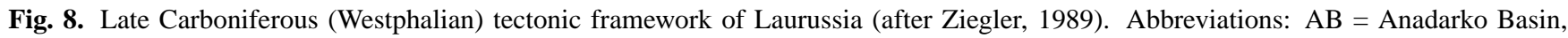
$\mathrm{ACB}=$ Aquitaine-Cantabrian Basin, $\mathrm{B}=$ Basin, $\mathrm{CINC}=$ Cincinnati Arch, NS = Alaska North Slope, NV = Nashville Dome, OZ = Ozark Uplift.

faults that developed in response to dextral translation of Africa relative to Europe during the Alleghanian orogeny of the Appalachians (Ziegler, 1989, 1990; Ziegler et al., 1995; Ziegler and Stampfli, 2001).

The evolution of the Rhenohercynian Zone reflects strong mechanical coupling of the Variscan orogenic wedge with its continental foreland at lithospheric levels during their initial collision, their mechanical decoupling during the subsequent Namurian-early Westphalian development of a typical flexural foreland basin and their increasing coupling during the terminal late Westphalian stages of the Variscan orogeny. Far field stresses related to collisional coupling of the Variscan Orogen with its European foreland are thought to have con- trolled the Late Carboniferous onset of crustal extension in the Norwegian-Greenland Sea area (Fig. 8) (Ziegler, 1989; Ziegler et al., 1995).

\subsubsection{Northwest African Variscan and Mauretanides Fore- land}

The north-western margin of Africa began to collide during the Late Devonian-Early Carboniferous with the Palaeotethys subduction system that governed the evolution of the Variscan Orogen. During the main phases of the Variscan orogeny, the collision front between Gondwana and Laurussia propagated eastward and south-westward in conjunction with the progressive closure of the Palaeotethys and 


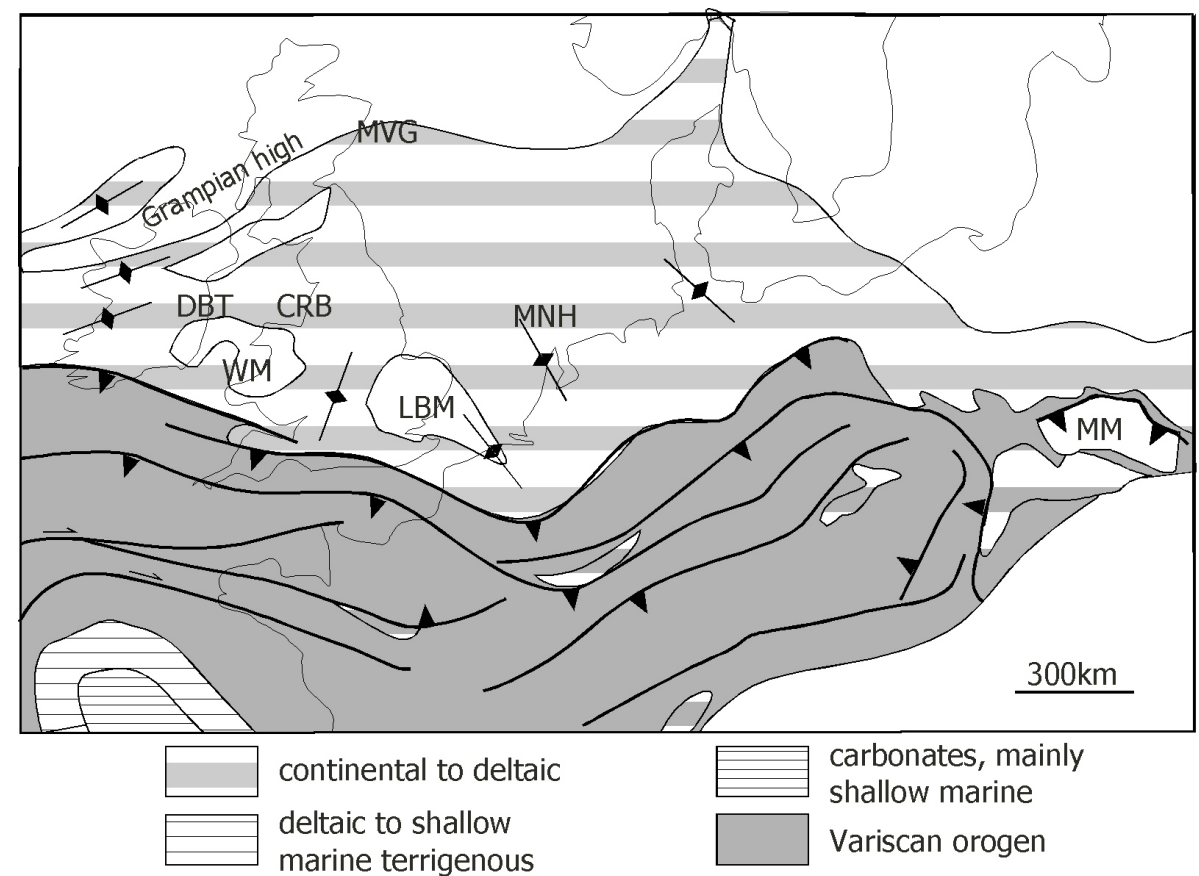

Fig. 9. Westphalian tectonic framework of the Northwest and Central European Variscan retro-wedge foreland basin, showing restored basin outlines, foreland inversion structures (anticlinal symbols) and main Variscan thrusts (barbed heavy lines) (after Ziegler, 1990). Abbreviations: $\mathrm{CRB}=$ Craven Basin, DBT $=$ Dublin Trough, LBM = London-Brabant Massif; MM = Malopolski Massif, MNH = Mid-Netherlands High, $\mathrm{MVG}=$ Midland Valley graben, $\mathrm{WM}=$ Welsh Massif.
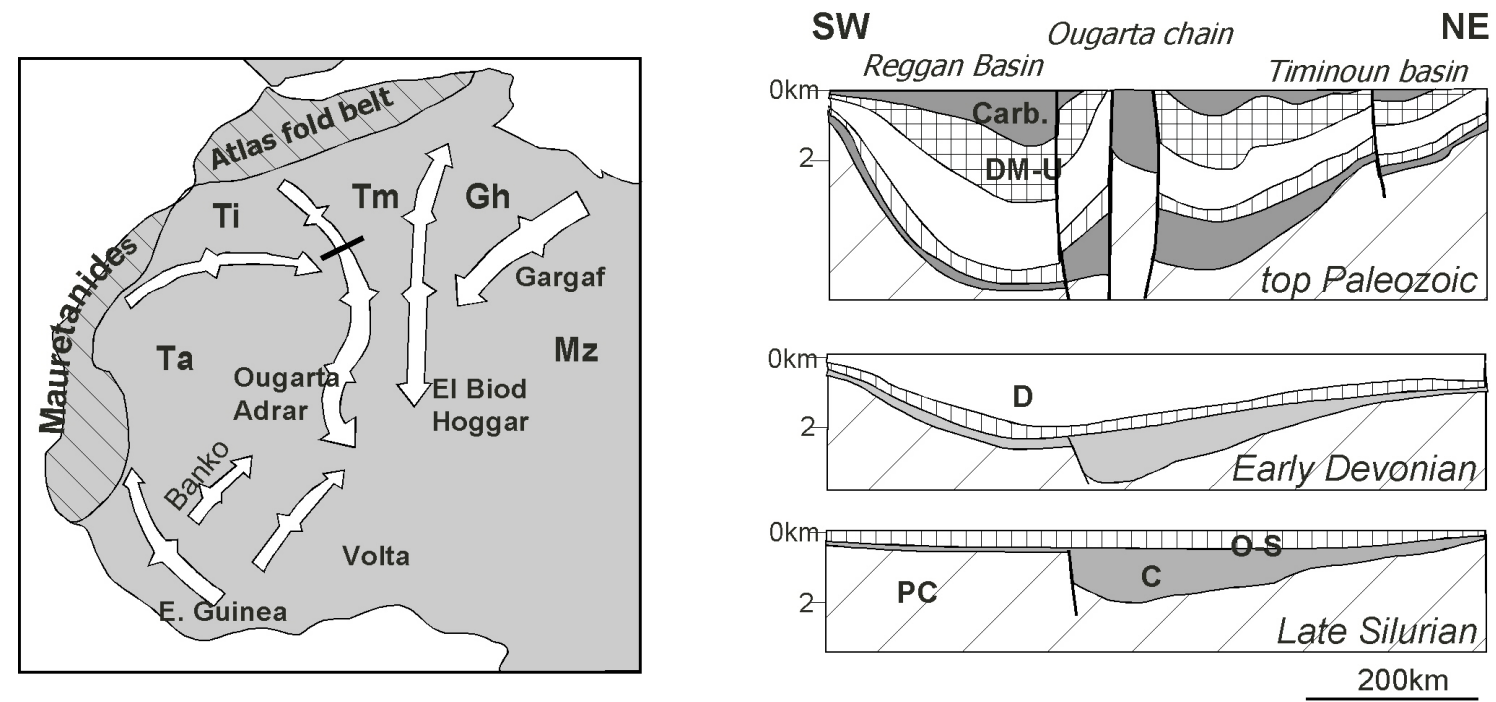

Fig. 10. Permo-Carboniferous intraplate deformation of the Sahara Platform, forming pro-wedge foreland of the Mauretanides-Atlas fold belt. White arrows indicate major arches. Schematic evolutionary diagram of the Ougarta Trough (after Ziegler, 1988). Abbreviations: Ti = Tinduff Basin, Ta $=$ Taoudeni Basin, Tm = Timimoun Basin, $\mathrm{Gh}=$ Ghadames Basin, Mz = Mourzouk Basin. For location see black bar on map.

Protoatlantic oceans, respectively. By Westphalian times, Gondwana had collided with the Appalachian arc-trench system (Fig. 8) (Ziegler, 1989, 1990; Stampfli, 1996; Stampfli et al., 2001; Ziegler and Stampfli, 2001).

During Early Carboniferous and Namurian times, a relatively narrow pro-wedge foreland basin developed along the northern margin of the Sahara Platform. However, increasing collisional coupling of the Variscan Orogen with the African Craton at lithospheric levels is evidenced by progressive inversion of the Cambro-Ordovician Saoura-OugartaAdrar rift, transpressional reactivation of the Panafrican ElBiot shear zone, and upwarping of the broad Reguibat Arch 


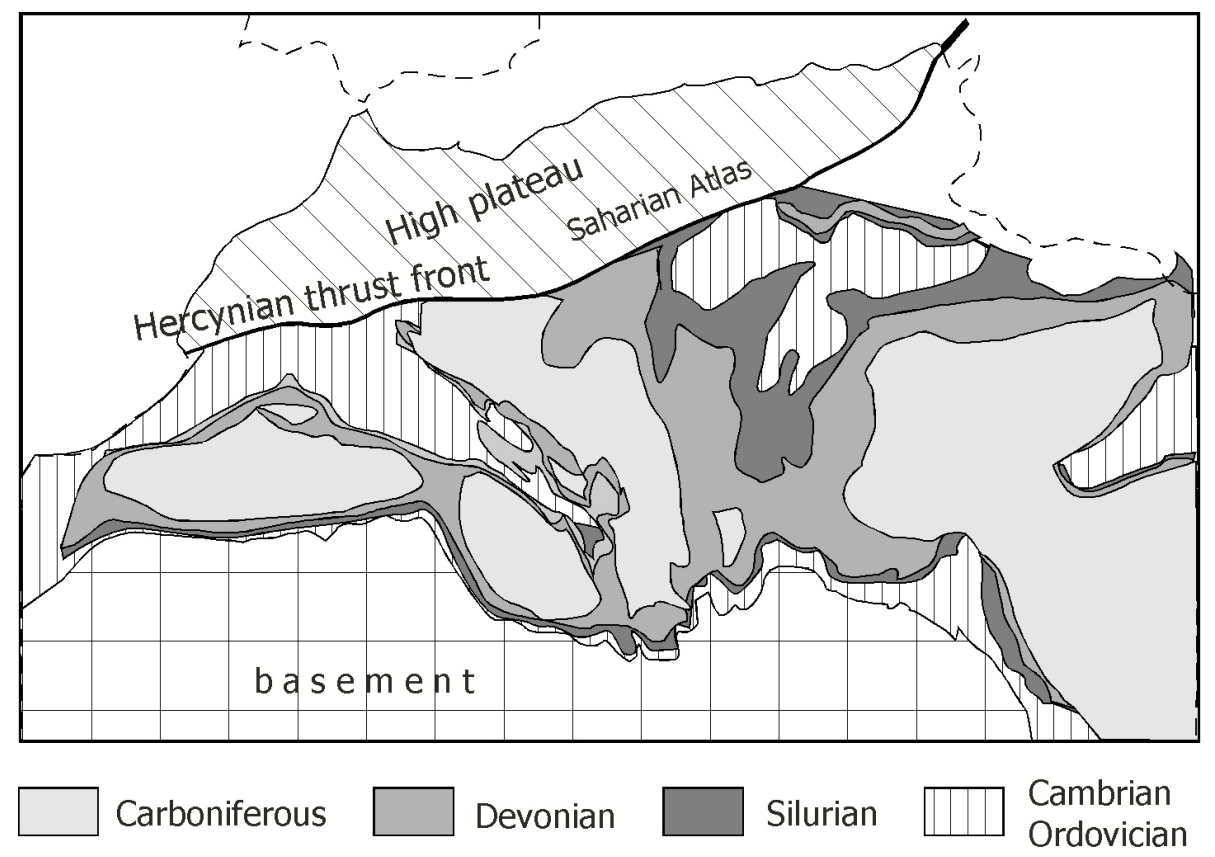

Fig. 11. Geological map of the northern Sahara Platform with Mesozoic and younger strata removed, showing subcrop pattern of Palaeozoic sediments beneath the Hercynian unconformity (after Boote et al., 1998).

(Fig. 10). This caused restriction and ultimately the Westphalian interruption of the marine sea-way that had linked the Palaeotethys and Protoatlantic seas via the Sahara Platform. Development of a classical flexural foreland basin was impeded by these important intraplate deformations, which extend over a distance of some $1200 \mathrm{~km}$ from the Variscan collision front into the area of the Hoggar Massif and caused disruption of the sedimentary cover of the Northwest African Shelf (Fig. 11) (Ziegler, 1988, 1989; Ziegler et al., 1995; Boote et al., 1998).

During the Westphalian and Early Permian development of the Mauretanides, intraplate compressional stresses caused further accentuation of the Reguibat Arch, separating the Taoudeni and Tinduff basins, and uplift of the East Guinea, Banko and Volta arches in West Africa (Fig. 10). Whether a pro-wedge foreland basin was associated with the Mauretanides is difficult to assess due to their intense postorogenic erosion (Ziegler, 1989).

The Late Palaeozoic evolution of the Sahara Platform reflects its increasing collisional coupling with the Variscan and Mauretanides orogenic wedges, presumably in response to their over-thickening and subduction resistance of the African Craton.

\subsubsection{Appalachian Foreland}

The Appalachian Basin is a classical retro-wedge foreland basin. Following Early-Middle Cambrian rifting, the Iapetus-Theïc Ocean began to open during the Late Cambrian and the Appalachian Shelf developed under a passive margin setting until its conversion into an active margin during the mid-Ordovician Taconic orogeny (Dykstra and Long- man, 1995). With this, the proximal parts of the Appalachian Shelf were incorporated into a foreland basin that evolved stepwise during the end-Silurian Salinian, Middle-Late Devonian Acadian and the Permo-Carboniferous Alleghanian orogenies (Figs. 8 and 12) (Quinlan and Beaumont, 1984; Tankard, 1986; Rast, 1998; Gao et al., 2000; see also Ziegler, 1989).

The Appalachian Basin is the type locality of viscoelastic flexural forebulges, such as the Taconic Waverly Arch and the westward adjacent Nashville-Cincinnati-FinlayAlgonquin Arch that came into evidence during the Acadian orogeny and underwent several uplift pulses during the Alleghanian orogeny. These arches essentially parallel the strike of the Appalachian Orogen and partly separated the Appalachian Basin from the contemporaneously subsiding intracratonic Illinois and Michigan sag basin (Fig. 12) (Quinlan and Beaumont, 1984; Tankard, 1986; Beaumont et al., 1987; Root and Onasch, 1999; Howell and van der Pluijm, 1999).

Subsurface data show, however, that the Early-Middle Cambrian rift system, that underlies the Appalachian foreland basin was repeatedly transpressionally reactivated during orogenic pulses, leading to partial inversion of e.g. the Rome Trough. Moreover, the location of the Cincinnati Arch appears to be preconditioned by basement discontinuities, partly related to the Grenvillian front and partly to Precambrian rifted basins (Root and Onasch, 1999; Gao et al., 2000). This suggests that during the Taconic, Acadian and Alleghanian orogenies compressional stresses were transmitted from the Appalachian collision zone into the foreland. Development of these arches may not so much have been 


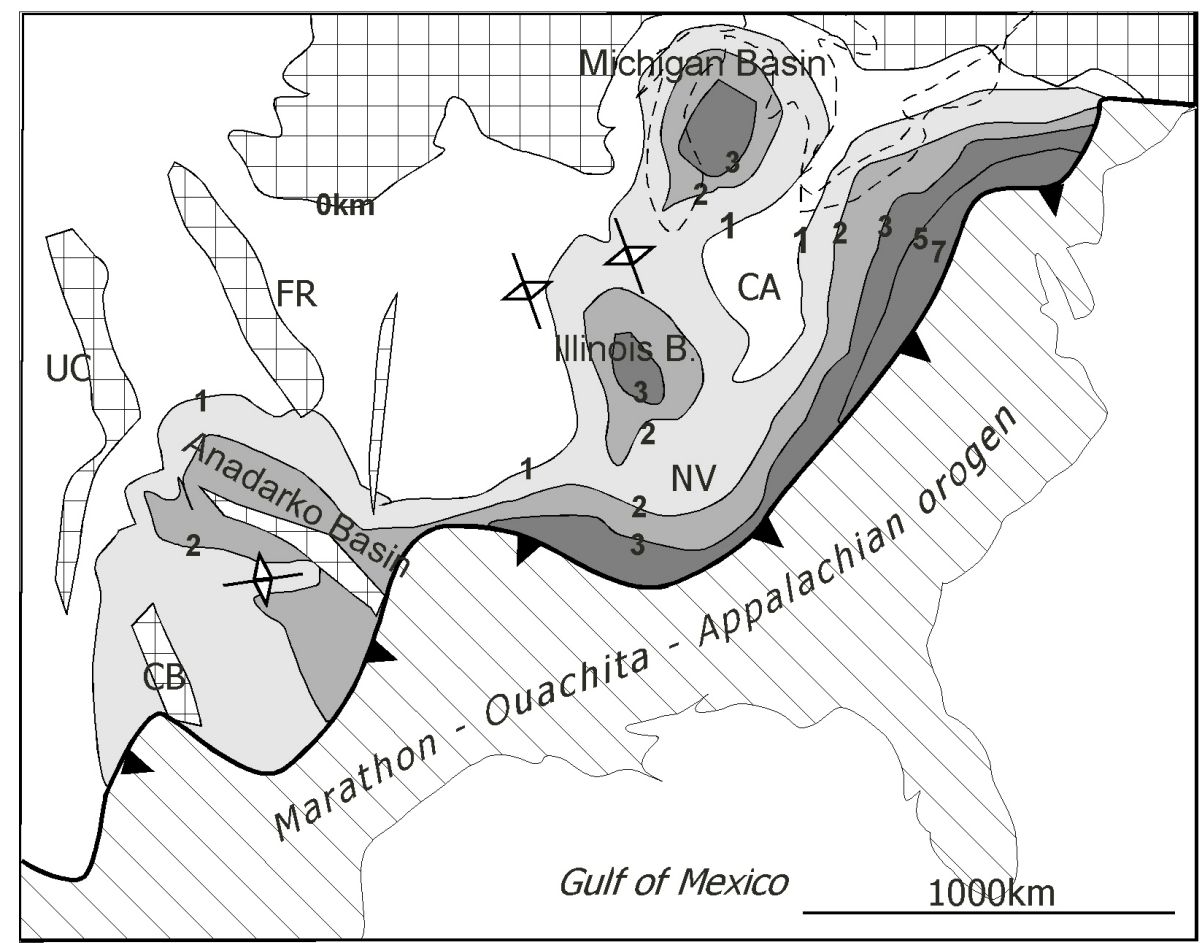

Fig. 12. Schematic tectonic map of Appalachian-Ouachita-Marathon retro-wedge foreland basin, showing major inversion structures (forming the Ancestral Rocky Mountains) and simplified depth contours at top-basement level in km. Cross-hatched area are basement highs. $\mathrm{CA}=$ Cincinnati-Finlay-Algonquin arch, $\mathrm{CB}=$ Central Basin Platform, FR = Frontrange Uplift, NV = Nashville dome, UC = Uncompahgre Uplift. Compiled from various sources.

controlled by the thrust load-induced deflection of the lithosphere and its visco-elastic relaxation, as proposed by Quinlan and Beaumont (1984) and Tankard (1986), than by the build-up of intraplate compressional stresses, inducing fault reactivation and arch accentuation by lithospheric folding. This concept is supported by the occurrence of upthrusted basement blocks in the Illinois Basin that developed during Late Mississippian through Pennsylvanian times in response to the build-up of intraplate compressional stresses (e.g. La Salle and Lincoln anticlines; McBriden and Nelson, 1999). As such, they reflect strong collisional coupling between the evolving Appalachian-Ouachita orogenic wedge and its foreland at lithospheric levels. Moreover, the Ordovician and Late Silurian-Middle Devonian pulses of accelerated subsidence of the Michigan Basin probably also reflect the buildup of intraplate compressional stresses at lithospheric levels during the Taconic and Salinian-Acadian orogenic cycles (Howell and van der Pluijm, 1999).

A feature of special interest is the erosional northern termination of the Appalachian external thrust belt and its associated foreland basin. In this respect, it is noteworthy that the northward adjacent Adirondack basement block was apparently uplifted along a system of reverse faults, delimiting it towards the St. Lawrence river, and a gentle flexure forming its south-western margin. Although fission-track data indicate that the Adirondack block was significantly uplifted during Middle Jurassic and Cretaceous times (Schofield et al., 1997; Roden-Tice, 1998), it cannot be excluded it was also uplifted during the Alleghanian orogeny along a system of crustal faults in conjunction with the build-up of major compressional stresses in the northern Appalachian foreland (Ziegler, 1989).

\subsubsection{Ouachita-Marathon Foreland}

The Ouachita-Marathon orogenic belt, which forms the south-western continuation of the Appalachians (Fig. 12), evolved in response to the Late Palaeozoic collision of Gondwana with the southern margin of the North American Craton. The onset of this collision is reflected by the MiddleLate Mississippian sharply accelerated subsidence of the deeper-water Ouachita Basin and the accumulation of thick flysch sequences derived from the evolving orogenic wedge bounding it to the south. During the Pennsylvanian, the northward adjacent shelf commenced to subside under the load of the advancing orogenic wedge; flexural bending stress caused the development of an array of normal faults in the foreland basin. By Late Desmoinesian times (Late Westphalian) the thrust front had reached its present location. During the Late Pennsylvanian-Early Permian, a basementinvolving duplex structure was up-thrusted in the internal parts of the Ouachita Orogen. Similarly, the progressively narrowing Marathon deep-water basin was converted during the Desmoinesian into a thrust belt (Arbenz, 1989; Meckel jr. et al., 1992). 


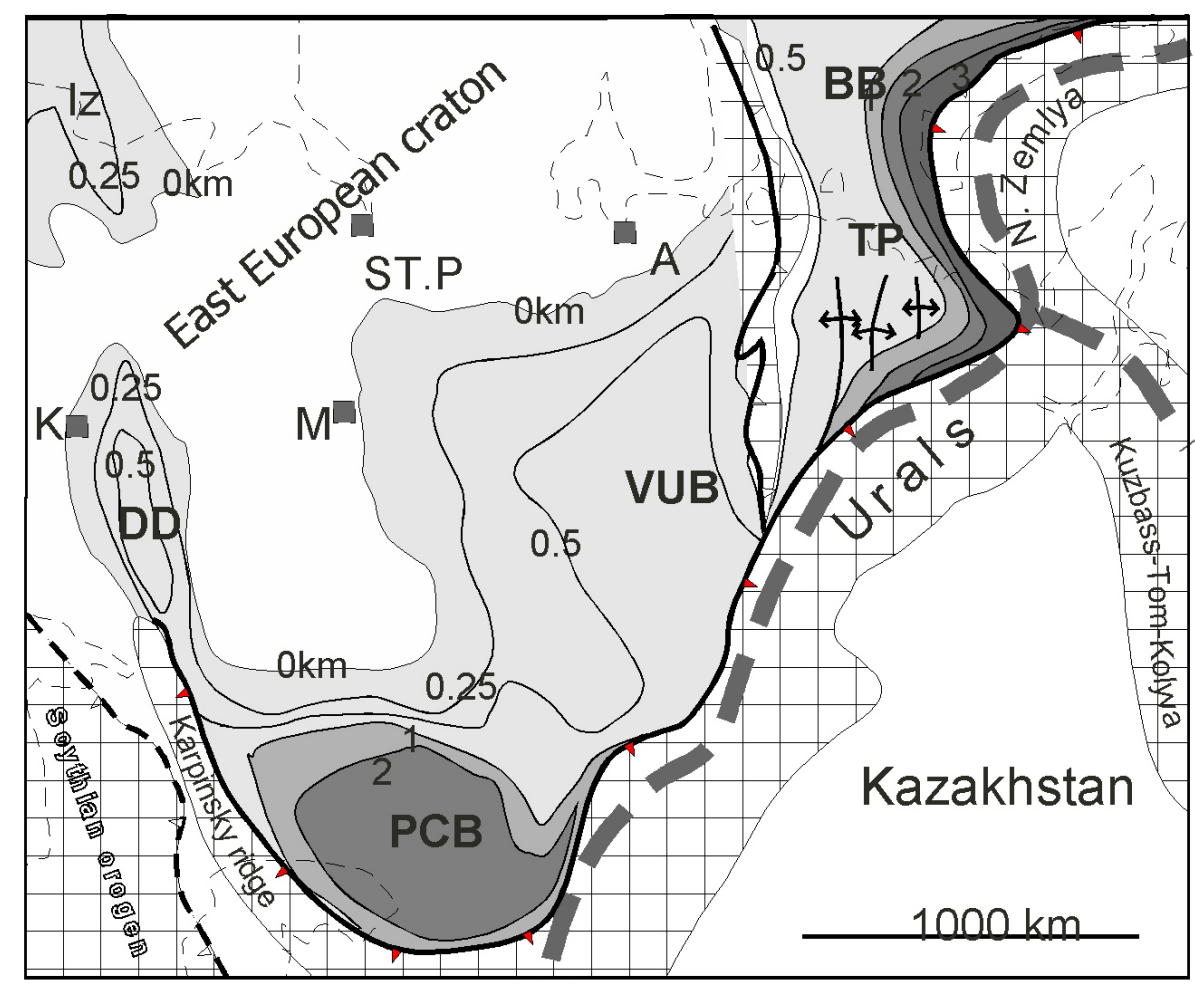

Fig. 13. Schematic tectonic map of pro-wedge Uralian foreland basin, showing simplified thickness contours in km for Late Permian series. Complied from various sources. Abbreviations: $\mathrm{BB}=$ Barents Sea Basin, DD = Dniepr-Donets Trough, $\mathrm{PCB}=\mathrm{Pericaspian} \mathrm{Basin}, \mathrm{TP}=$ Timan-Pechora Province, VUB = Volga-Ural Basin. Cross-hatched = orogenic belts, broken dark grey band = sutures. Squares: major cities $\mathrm{A}=$ Archagel'sk, $\mathrm{K}=\mathrm{Kiev}, \mathrm{M}=$ Moscow, ST.P $=$ St. Petersburg.

During the latest Carboniferous to Early Permian, major compressional stresses were exerted on the retro-wedge foreland, causing the development of the Ancestral Rocky Mtns. These are characterized by an array of upthrusted basement blocks and intervening transtensional fault-bounded basins (Fig. 12) (Ross and Ross, 1986; Kluth, 1986; Stevenson and Baars, 1986; Oldow et al., 1989; McBriden and Nelson, 1999). The most distal transpressional structures are located some $1500 \mathrm{~km}$ to the north of the contemporaneous Marathon-Ouachita thrust front (Ziegler, 1989; Ziegler et al., 1995), with compressional microtectonic deformation evident at distances of up to $1700 \mathrm{~km}$ (Craddock et al., 1993; van der Pluijm et al., 1997).

Development of the Ancestral Rocky Mtns. commenced during the Late Mississippian-Early Pennsylvanian (Chesterian-Morrowian, Namurian) and ended essentially during the Early Permian (Ziegler, 1989; Ye et al., 1996). Their Late Pennsylvanian-Early Permian evolution was accompanied by upthrusting of internal crystalline massifs in the Ouachita Orogen (Arbenz, 1989). This reflects increasing collisional coupling between the Ouachita-Marathon Orogen and its foreland, at least at crustal levels, starting already during the subsidence of its flexural foreland basin and intensifying during the Late Pennsylvanian and Early Permian partial destruction of the latter.

\subsubsection{Uralian Foreland}

The Uralian Orogen and its northern continuation in Novaya Zemlya developed during the Late Palaeozoic collision of the Kazakhstan terrane and the Siberian Craton with the passive eastern margin of the East-European Craton and the Barents Sea Shelf. Major pro-wedge foreland basins are associated with the southern and central Urals and the Novaya Zemlya Orogen, whereas in the foreland of the Polar Urals and PayKhoy, the Timan-Pechora province, syn-orogenic inversion of Devonian rifts interfered with the development of a distinct foreland basin (Fig. 13) (Nikishin et al., 1996; Fokin et al., 2001).

The Uralian Ocean began to open during the Ordovician. During the Silurian, the intra-oceanic SakmarianMagnitogorsk arc, that was associated with a west-dipping subduction zone, came into evidence, partitioning the Uralian Ocean into the Sakmarian back-arc and the Uralian fore-arc basins (Fig. 4). During Middle and Late Devonian times, plume-assisted back-arc extension affected the eastern margin of the East-European craton and the Sakmarian Basin (Fig. 6). Late Frasnian-earliest Famennian back-arc compression, resulting in upthrusting of basement blocks in the future southern Uralian foreland, can be related to collision of the Mugodjary terrane with the Magnitogorsk arctrench system. Following Early Carboniferous collision of the Kazakhstan terrane with the Siberian Craton and their 


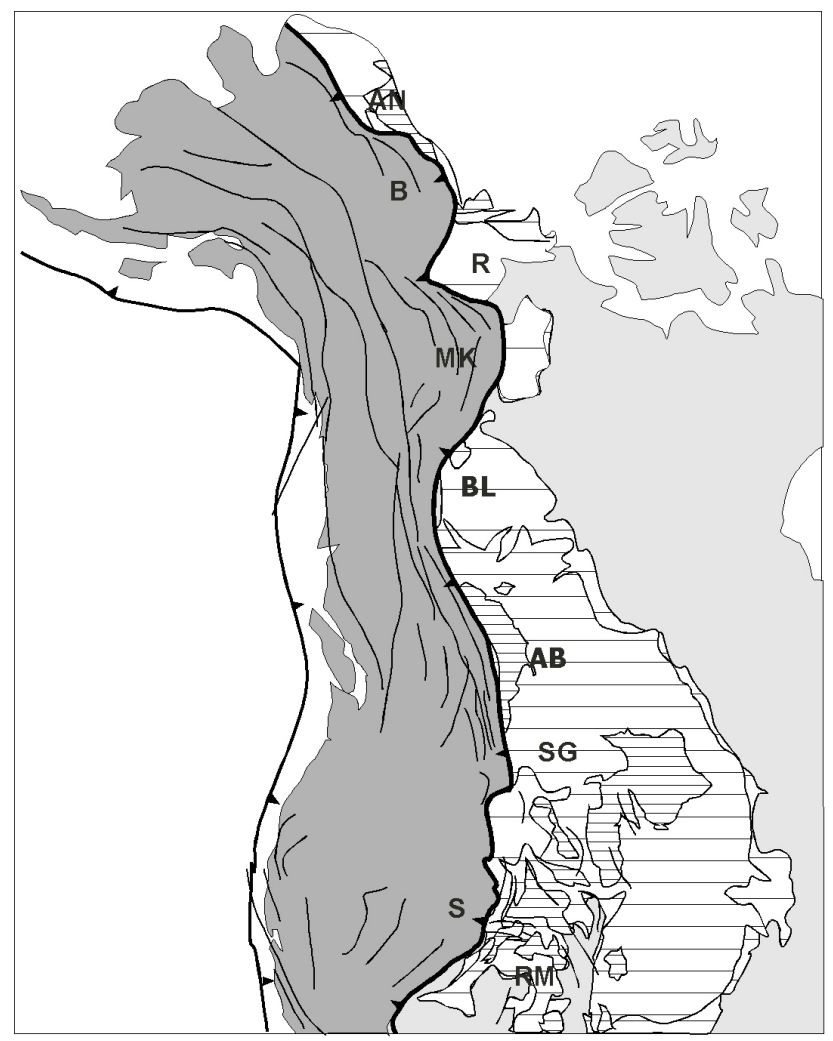

Paleogene

Upper Cretaceous

Upper Jurassic - Lower Cretaceous

Fig. 14. Schematic tectonic framework of Cordilleran retro-wedge foreland basin, showing present distribution of Late Jurassic-Early Cretaceous, Late Cretaceous and Paleogene syn-flexural series (after Cook and Bally, 1975, Bally, 1989). Abbreviations: AB = Alberta Basin, $\mathrm{AN}=$ Alaska North Slope, $\mathrm{BL}=$ Bekami Lake, $\mathrm{B}=$ British-Romanzof Mtns., MK = Mackenzie Mtns., $\mathrm{R}=$ Richardson Mtns., RM = Rocky Mtns., $\mathrm{S}=$ Sevier thrust Belt, $\mathrm{SG}=$ Sweetgrass Arch.

joint collision with the Magnitogorsk-Mugodjary arc-trench system, its west-dipping subduction system was abandoned and a new east-dipping one developed along its western margin (Fig. 8). This subduction system controlled the closure of the Sakmarian Basin and the evolution of the Uralian Orogen until Late Permian times (Ziegler, 1989; Zonenshain et al., 1990; Nikishin et al., 1996).

During the Early Visean reorganization of the Magnitogorsk-Mugodjary subduction system, compressional stresses were exerted on the East-European craton, inducing wide-radius arching, the development of a regional unconformity and inversion of Devonian rifts in the Volga-Ural Province. Oblique collision of the evolving Uralian orogenic wedge with the East-European passive margin accounted for the time transgressive onset of its thrust-loaded subsidence, commencing in the south during the Late Visean-Serpukhovian whereas in the Barents Sea it commenced during the Early Permian (Fokin et al., 2001). At the Sakmarian-Artinskian transition, convergence between the Uralian orogenic wedge and the East-European craton changed from oblique to cylindrical (Puchkov, 1997); with this thrust-loaded subsidence of the Uralian foreland basin accelerated. At the same time the Vyatka, Timan and Pechora-Kolva and numerous smaller rifts were inverted (Nikishin et al., 1996). This interfered with the development of a flexural foreland basin, particularly in the TimanPechora sector (Sobornov and Tarasov, 1994). During the Late Permian, the Uralian Orogen became inactive, whilst the Pay-Khoy-Novaya Zemlya thrust belt was affected by a last, though major phase of crustal shortening at the Triassic-Jurassic transition Nikishin et al., 1996; Fokin et al., 2001).

The external parts of the Urals are characterized by thin skinned thrust sheets and more internal basement-involving thrust stacks, the geometry of which were controlled by Precambrian rifts (Zonenshain et al., 1990; Perez-Estaún et al., 1997).

Mechanical coupling between the Uralian Orogen and its foreland varied through space and time, generally increased during the late orogenic phases and was particularly strong at crustal levels in the Timan-Pechora sector. Conversely, coupling of the Novaya Zemlya Orogen with its foreland was largely restricted to sedimentary levels, as evidenced by the lack of major inversion structures in the eastern Barents Sea and the preservation of a very deep foreland basin (Nikishin et al., 1996). Similarly, the deep Pericaspian Basin, that evolved in response to tectonic loading of the East-European platform by the Urals in the east and by the Karpinsky Swell in the south, shows no evidence for intraplate compressional deformation (Nikishin et al., 1996, 2001; Fokin et al., 2001).

\subsection{North American Laramide Cordilleran foreland}

Major Cretaceous to Paleogene retro-wedge flexural foreland basins are only preserved in the foreland of the Brooks Ranges in Alaska (Bird and Molenaar, 1992) and the Canadian Cordillera of British Columbia and Alberta (Leckie and Smith, 1992). In the sectors of the Canadian Mackenzie Mtns. (Ziegler, 1969) and the USA Sevier thrust belt (Gries et al., 1992), pre-existing foreland basins were disrupted during the Late Cretaceous-Paleogene Laramide orogeny (Fig. 14; Oldow et al., 1989). The following discussion concentrates on areas which lack well developed foreland basins.

During Middle Jurassic-Early Cretaceous times, a continuous flexural foreland basin extended from the Arctic Sea to the Gulf of Mexico, into which clastics were shed from the evolving Cordilleran Orogen. During Aptian to Santonian times, this basin widened and broadly overstepped its eastern margin, providing for intermittent marine communications between the Arctic Sea and the Gulf of Mexico. However, these were permanently severed during the Campanian in conjunction with rapid thrust propagation into the foreland in the area of the Mackenzie Mtns. (Ziegler, 1969; Frazier and 


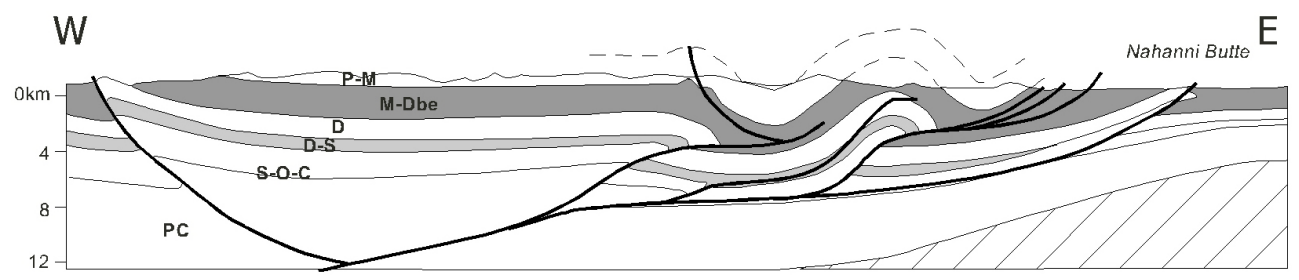

\section{Mackenzie Mts}

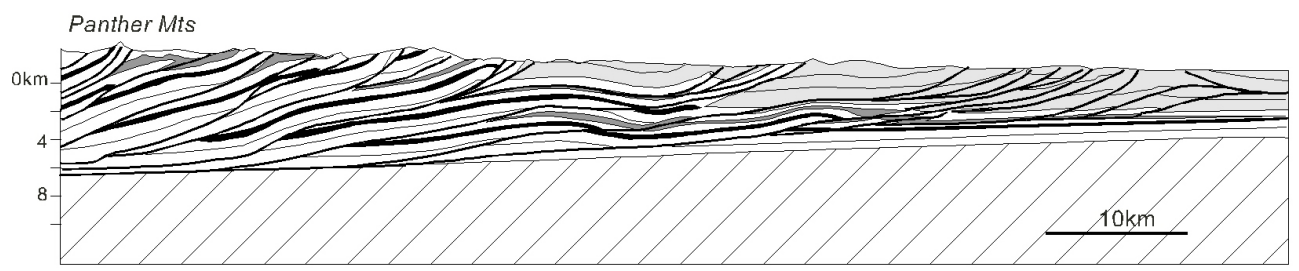

Alberta foothills and Front Ranges
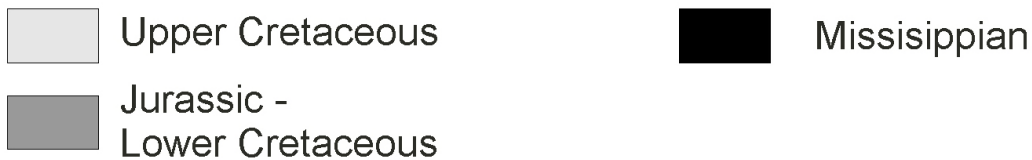

Lower Cretaceous

Fig. 15. Structural cross-sections through southern Mackenzie Mtns. and Alberta foothills and front ranges at same scale, illustrating changes in structural style related to thickness of the imbricated sedimentary sequence and the distribution of detachment levels within it.

Schwimmer, 1987; Bally, 1989; Leckie and Smith, 1992). Nevertheless, subsidence of the Alaskan North Slope and the Western Canada foreland basins persisted until the midEocene termination of the Laramide orogenic cycle (Bird and Molenaar, 1992; Leckie and Smith, 1992; Stockmal et al., 1992).

During the Jurassic-Early Cretaceous tectonic loading of the North American Craton, the Cordilleran foreland basin was nearly linear, and, as far as can be judged, relatively narrow. A regional base Jurassic unconformity has been attributed to the development of a forebulge, involving flexural deflection of the relatively weak lithosphere of the North American continental margin (Stockmal et al., 1992). This unconformity may also have resulted from tangential stresses that were exerted onto the North American passive margin during its the initial collision with the Cordilleran orogenic wedge (after closure of the Late Carboniferous oceanic Havallah back-arc basin during the Permo-Triassic Sonoma Orogeny: Oldow et al., 1989). Cretaceous progressive broadening of the Cordilleran foreland basin, accompanied by the development of a series of less profound "forebulge" unconformities, suggests that increasingly stronger lithosphere was deflected by the load of the advancing orogenic wedge (Stockmal et al., 1992). However, eustatic and perhaps stress-induced relative sea-level fluctuations apparently played an important role in the development of this system of low relief unconformities (Bally, 1989; Jervey, 1992), casting some doubt on their relation to "forebulge" development.
From mid-Cretaceous times onwards, the OgilvieMackenzie Mtns. and the British Mtns.-Nahoni Range salients developed in response to thrust propagation into the foreland, modifying the geometry of the Cordilleran foreland basin (Fig. 14). These salients were preconditioned by the presence of very thick Late Precambrian sediments and the "soft" basement of the Inuitian Orogen, respectively. In the Mackenzie salient, thin-skinned thrusts propagated far into the foreland during the late Senonian and Paleogene, involving very thick Late Precambrian and Palaeozoic sediments (Fig. 15), partly reactivating pre-existing fracture systems that control the geometry of the Franklin Mtns. which are characterized by system of interference folds (Oldow et al., 1989). At the same time, the Early Palaeozoic extensional Richardson Mtns. Trough was inverted in response to the build-up of compressional foreland stresses at crustal levels (Fig. 16) (Ziegler et al., 1995). This resulted in a profound disruption of the Late Cretaceous foreland basin and the Campanian isolation of its southern parts from the Arctic seas (Ziegler, 1969; Leckie and Smith, 1992).

The external parts of the Alberta, and to a degree also of the British Columbia sectors of the Cordillera are characterized by thin-skinned thrust sheets, employing multiple sedimentary detachment levels, that involve a generally much thinner pre-flexural sedimentary sequence, partly due to the presence of a much thinner Late Precambrian sequence (Fig. 15) (Bally et al., 1966; Ziegler, 1969; Oldow et al., 1989). Despite major supra-crustal shortening, thrusting did 

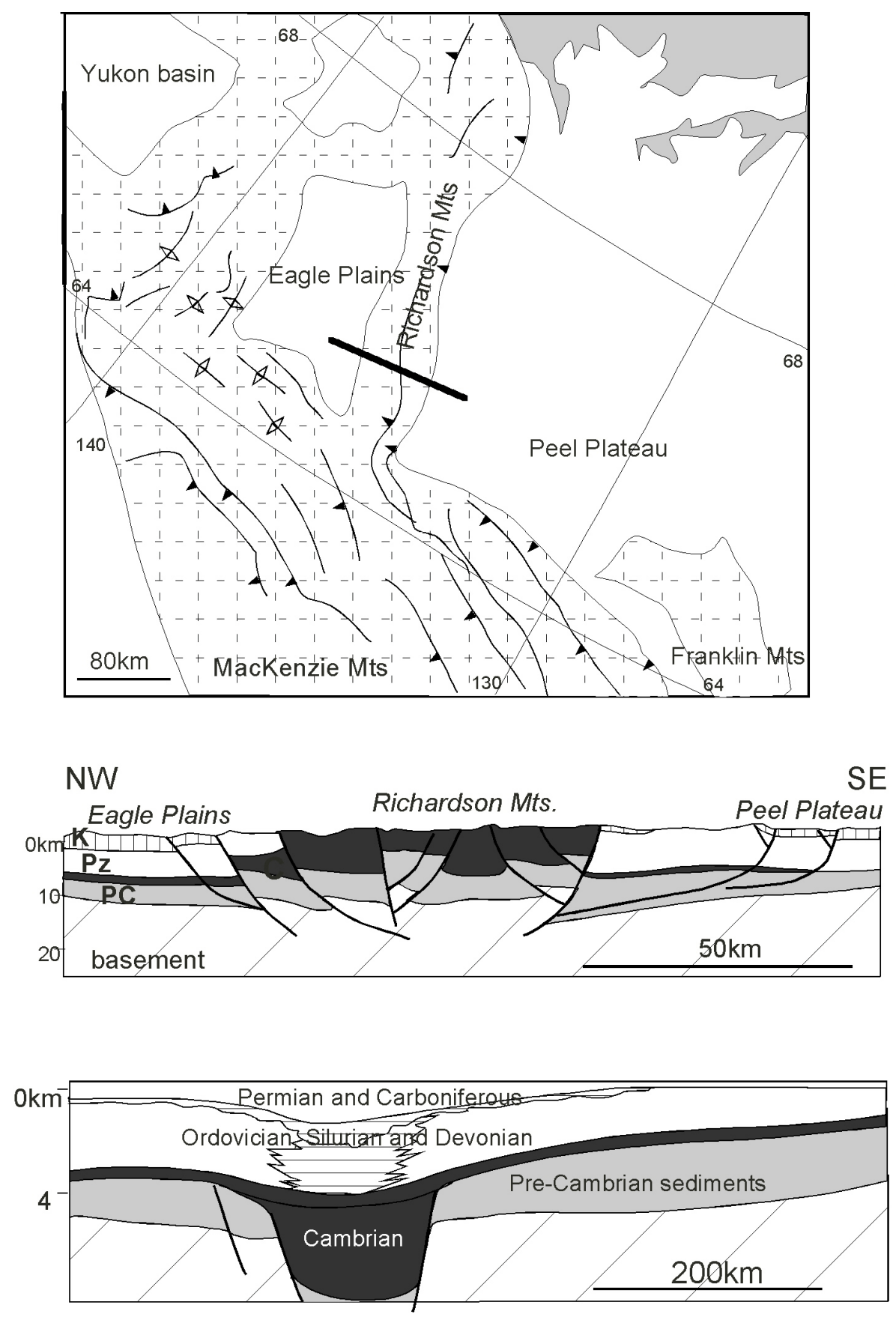

Fig. 16. Inverted Early Palaeozoic Richardson Mtns. Trough, northwestern Canada. Location map showing position of cross-section. Structural cross-section and its schematic palinspastic restoration, illustrating Ordovician-Devonian shale basin and adjacent carbonate platforms superimposed on Cambrian rift and its flanks (modified after Ziegler et al., 1995).

not propagate as far into the foreland basin as in the Mackenzie salient. Thus, the foreland basin of Alberta and north-east British Columbia is still largely preserved, despite its significant uplift during post-Laramide times. Syn-flexural normal faults, related to bending stresses, are conspicuously absent in these basins and the adjacent foothills thrust belt (Bally et al., 1966), reflecting a high $\mathrm{T}_{\mathrm{e}}$ of the lithosphere and a low curvature of its deflection.

In the foreland of the Sevier trust belt, upthrusting of the array of basement blocks forming the Rocky Mtns. commenced during the Campanian and persisted until midEocene times (Fig. 17). This caused a deep disruption of the proximal parts of the Cretaceous flexural foreland basin and an interruption of the seaway that had extended from the Gulf of Mexico northwards into the West-Canadian foreland basin (Gries et al., 1992). These basement blocks are carried by listric reverse faults which sole out at lower crustal levels. Crustal shortening achieved in this thick-skinned foreland 

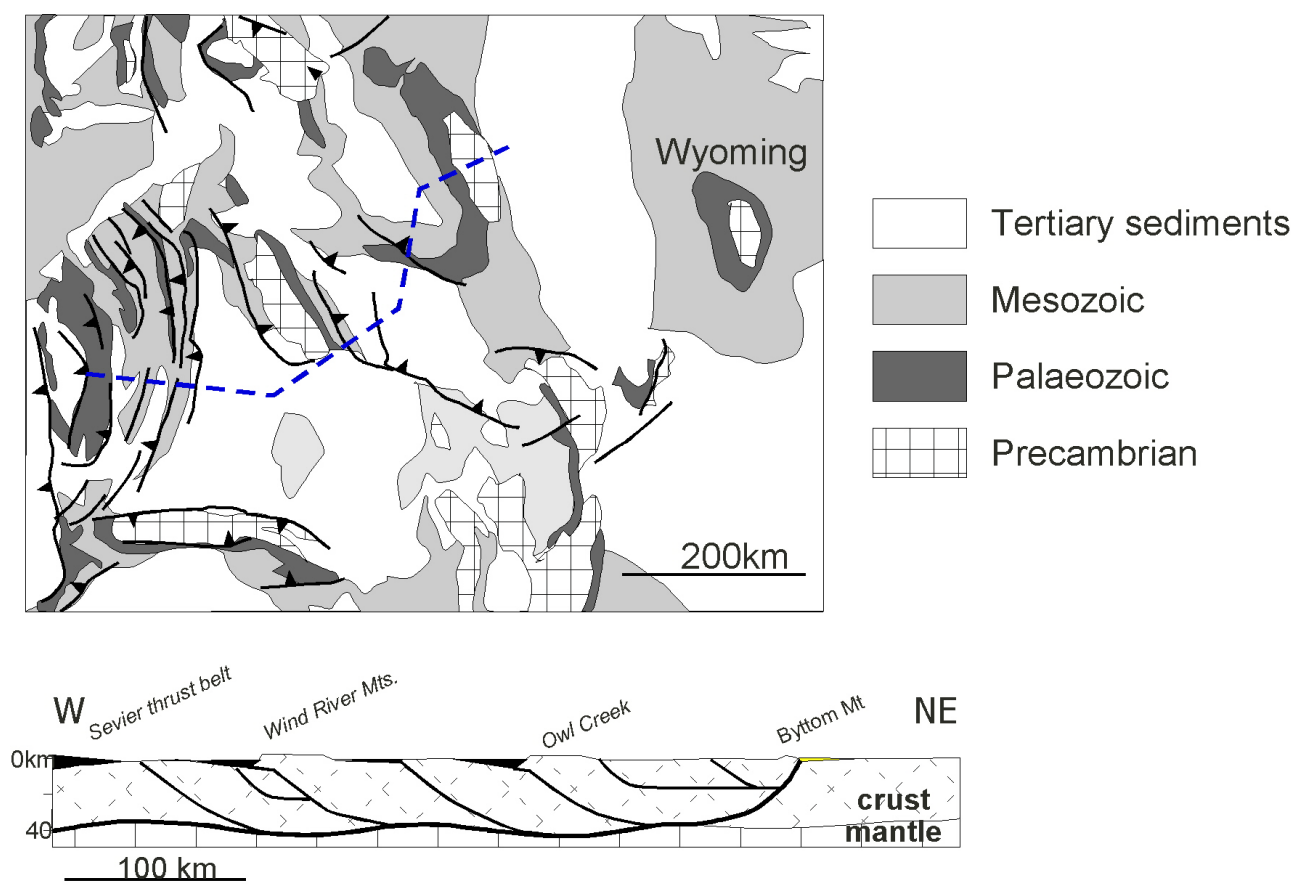

Fig. 17. Tectonic elements of the Laramide Rocky Mountains, western U.S.A. and balanced cross-section (modified after Bally and Snelson, 1980; Egan and Urquhart, 1993).

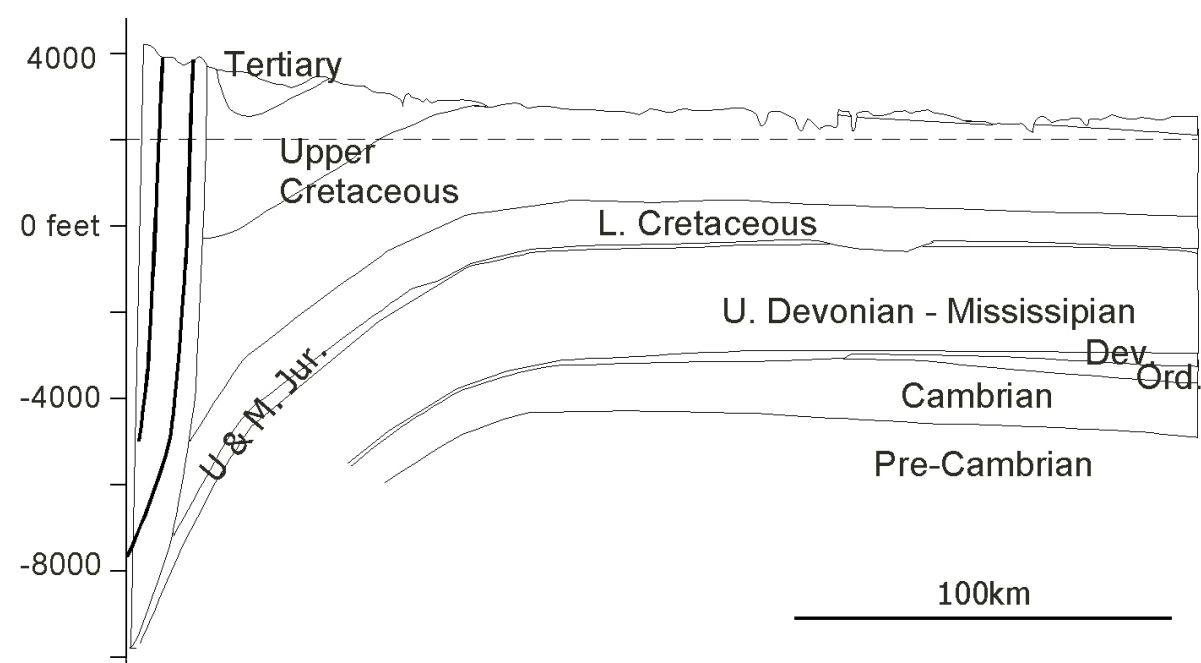

Fig. 18. Schematic cross-section through Sweetgrass Arch, straddling US-Canadian border in Cordilleran foreland (after AAPG Highway map Alberta).

thrust belt amounts to some $35 \mathrm{~km}$ and was presumably compensated at mantle levels at the Cordilleran A-subduction zone. The most distal compressional foreland structures of the Rocky Mtns. occur $750 \mathrm{~km}$ to the east of the thin-skinned Sevier thrust belt (Oldow et al., 1989; Egan and Urquhart, 1993; Ziegler at al., 1995). Development of the Rocky Mtns. indicates that during the Laramide orogeny mechanical coupling of the Cordilleran Orogen with its foreland progressively increased at crustal levels, possibly in response to over-thickening of the orogen (Ziegler et al., 1998).

Evolution of the Rocky Mtns. was accompanied by
Eocene alkaline intrusive and extrusive magmatic activity that is attributed to low-degree partial melting of the lithospheric thermal boundary layer (Cook and Bally, 1975; Oldow et al., 1989), possibly in response to its decompression in conjunction with broad lithospheric folding. Similarly, Paleogene uplift of the broad Sweetgrass Arch, which straddles the US-Canadian border in the Cordilleran foreland, was punctuated by alkaline magmatic activity (Fig. 18) (Leckie and Smith, 1992). Development of this arch, which is unique in the Cordilleran foreland and has an amplitude of up to $1000 \mathrm{~m}$, can be attributed to folding of the entire 

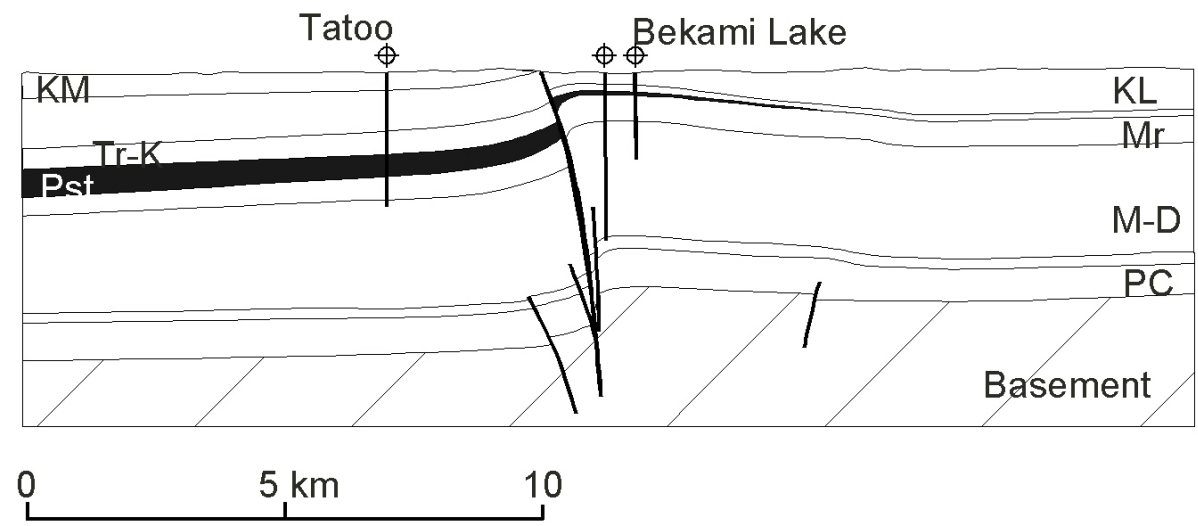

Fig. 19. Cross-section through Bekami Lake structure, northeastern British Columbia, showing Laramide compressional reactivation of a Pennsylvanian extensional fault (same vertical and horizontal scale). PC = Late Precambrian sediments, M-D = Mississippian-Devonian; $\mathrm{Mr}=$ Mississippian carbonates; Pst = Pennsylvanian clastics, $\mathrm{Tr}-\mathrm{K}=$ Triassic to Cretaceous; KL = Lower Cretaceous, KM = Middle Cretaceous.

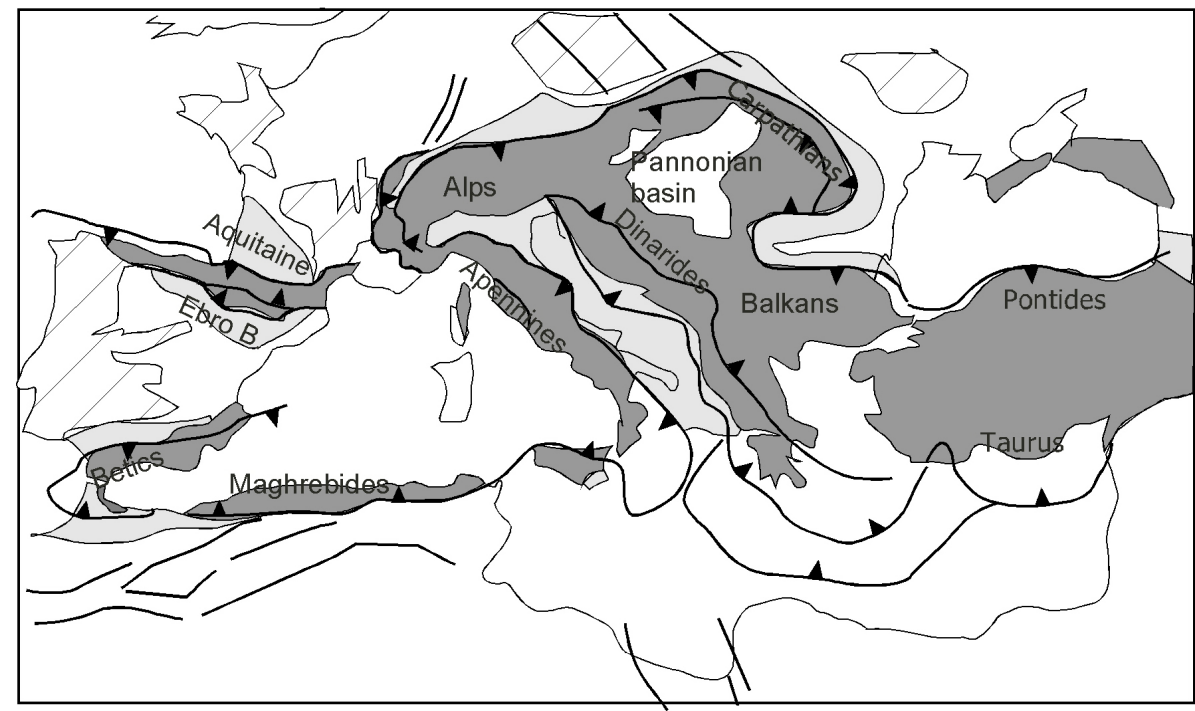

orogenic belts

foredeep basins

basement highs

Fig. 20. Tectonic framework of the Alpine-Mediterranean area, showing distribution of orogenic belts, flexural foreland basins and major basement uplifts in forelands (modified after Ziegler and Roure, 1999).

lithosphere in response to the build-up of intraplate compressional stresses, rather than to its thrust-loaded deflection and visco-elastic relaxation, as advocated by Beaumont (1981).

The above suggests that during the late phases of the Laramide orogeny the Cordilleran Orogen was mechanically strongly coupled at lithospheric levels with its foreland in the area between the US-Canadian border and New Mexico. Conversely, north of the Canadian border, compressionally reactivated basement faults are virtually absent. A notable exception is the Pennsylvanian Bekami Lake normal fault in NE. British Columbia (Fig. 19). This suggests that in this area the orogenic wedge was only weakly coupled with its foreland at crustal and mantle-lithospheric levels, whereas significant supra-crustal shortening accounts for its strong coupling at sedimentary levels. However, inversion of the Early Palaeozoic Richardson Mtn. Trough (Fig. 16) (Ziegler et al., 1995), reflects that, at least at crustal levels, compressional stresses were transmitted into the foreland of the northernmost Cordillera.

\subsection{Forelands of the Alpine-Mediterranean Orogen}

Main elements of the Alpine-Mediterranean orogenic system are the Alpine, Carpathians-Balkans, Dinarides-AlbanidesHellenides-Taurus, Apennine-Maghrebides-Betic and Pyrenean thrust belts (Fig. 20). More or less well developed pro- 

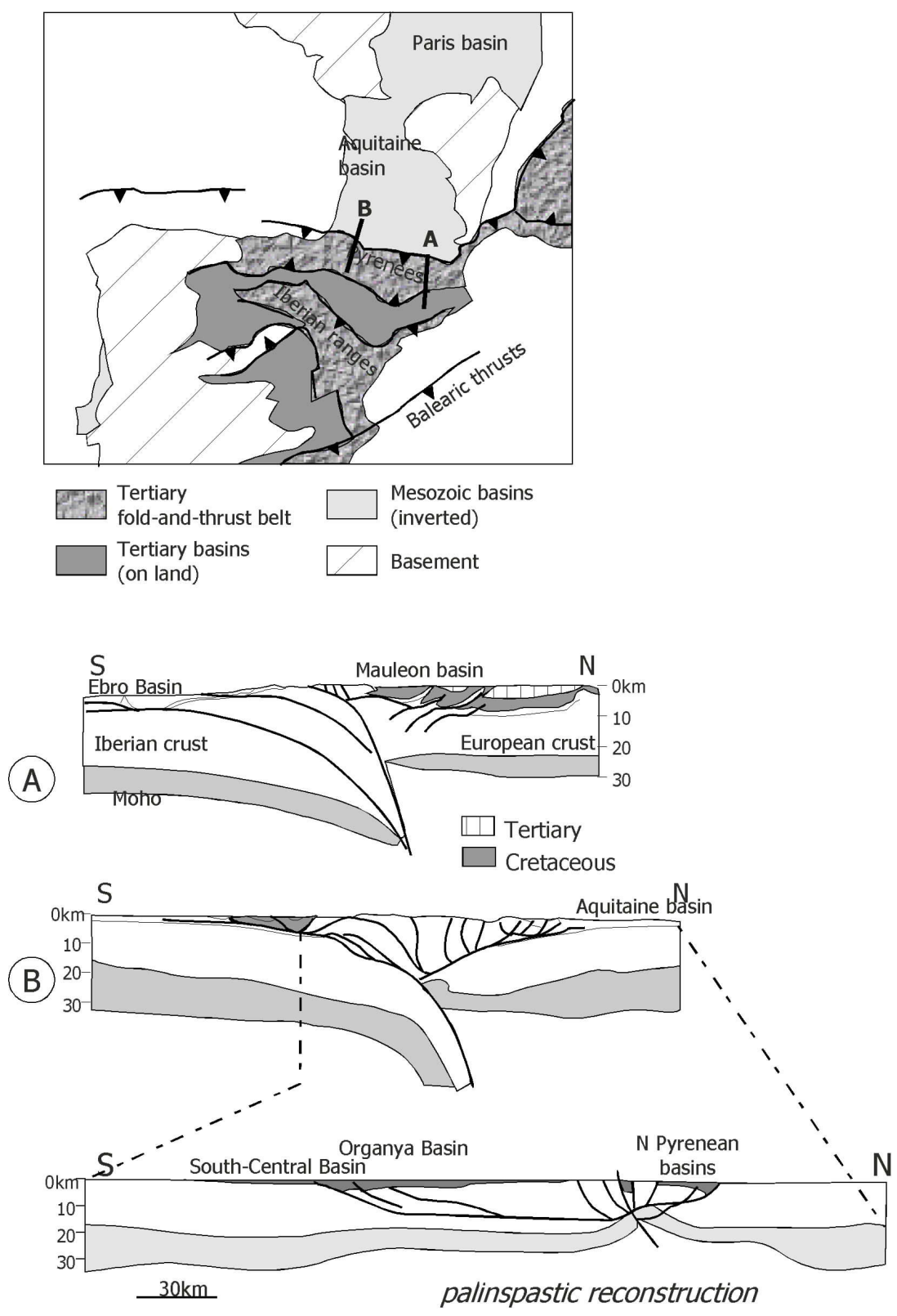

Fig. 21. Tectonic framework of Iberia (after Ziegler, 1988), showing location of structural cross-sections A and B through the Pyrenees. Palinspastic restoration of cross-section B (after Vérges and García-Senez, 2001).

wedge foreland basins are associated with the Apennine and the Taurus, the Central and Eastern Alps and the Carpathians. Typical retro-wedge foreland basins are associated with the Southern Alps and the Balkanides. During the evolution of the Pyrenees, the Ebro Basin developed in a pro-wedge setting, whereas the Aquitaine Basin developed in a retrowedge setting. Below we review the evolution of some of these forelands.

\subsubsection{Pyrenean Foreland Basins}

The Pyrenean fold-and-thrust belt (Fig. 21) evolved during late Senonian to Oligocene times in response to convergence of Africa with Europe. However, as the northwest-dipping
Betic-Balearic subduction system gained in importance during the late Eocene and Oligocene, strain was gradually concentrated on the southern margin of Iberia at the expense of the Pyrenean system. The latter became inactive with the late Oligocene onset of rifting in the Balearic back-arc domain (Gueguen et al., 1998; Séranne, 1999; Roca, 2001; Stampfli et al., 2001).

Development of the Pyrenees involved some $135 \mathrm{~km}$ of crustal shortening and northward subduction of the Iberian lithosphere beneath Europe (Fig. 21). Correspondingly, the Ebro foreland basin developed in a pro-wedge setting whereas the conjugate Aquitaine Basin evolved in a retrowedge setting. The western extension of the Pyrenean sys- 
tem is formed by the Cantabrian fold-and-thrust belt, which is associated with a south-dipping subduction zone along which some $50 \mathrm{~km}$ of oceanic lithosphere of the Bay of Biscay were consumed. The switch in subduction polarity between the Pyrenees and the Cantabrian system occurs in the region of Pamplona (Engeser and Schwentke, 1986; Turner, 1996). In Cantabria, inversion and southward thrusting of the Mesozoic extensional Cantabrian-Basque Basin inhibited the development of a retro-wedge foreland basin (Vergés and García-Senez, 2001).

Crustal shortening commenced in the Pyrenees during the Senonian, initially inducing inversion of Mesozoic extensional basins in the Pyrenean rift system. Thrust-loading of the Iberian foreland commenced during the late Paleocene and progressively increased during the Eocene, controlling the gradual subsidence of the flexural pro-wedge Ebro Basin, where marine carbonates and clastics transgressed over an end Cretaceous regional unconformity (Vergés et al., 1998). It is unlikely that this unconformity can be related to the development of a flexural forebulge as by this time a foreland basin had not yet developed. During Paleocene-Eocene times, compressional stresses exerted on the northeastern retro-wedge Pyrenean foreland caused the development of the Languedoc-Provençe fold-and-thrust belt, involving the inversion of Mesozoic extensional basins; this inhibited the development of a flexural foreland basin (Roure and Colletta, 1996). By contrast, further west, thrust loading of the European lithosphere caused the subsidence of the Aquitaine retro-wedge foreland basin (Le Vot et al., 1996).

By late Eocene times, crustal shortening in the Pyrenean system was apparently no longer able to accommodate the majority of the Africa-Europe convergence, as evidenced by increased activity along the Betic-Balearic subduction system and the build-up of compressional stresses within cratonic Iberia. The latter controlled up-thrusting of the Sierra Guaderrama basement block and inversion of the Mesozoic extensional Iberian and Catalan Coast Ranges basins. This resulted in tectonic silling of the Ebro Basin which thus assumed its present triangular shape and became separated from the adjacent seas (Gaspar-Escribano et al., 2001). Rapid Late Eocene and Oligocene uplift of the Pyrenees, involving imbrication of the Iberian and European crust and thrust propagation into the conjugate forelands (Fig. 21) (Séguret and Dagnères, 1985; Vergés and García-Senez, 2001), reflects increasing collisional coupling between the orogenic wedge and its forelands at crustal levels, presumably in response to the development of a European mantle back-stop (Ziegler and Roure, 1996). Moreover, progressive lengthening of the subducted Iberian lower crustal and mantle lithospheric slab exerted an additional load on the Iberian foreland, thus contributing to the flexural subsidence of the pro-wedge Ebro Basin (Gaspar-Escribano et al., 2001). Rapid erosion of the rising Pyrenees was accompanied by the accumulation of $2-3 \mathrm{~km}$ thick continental clastics in the tectonically silled Ebro Basin, exerting an additional load on its lithosphere.

Towards the end of the Oligocene, crustal shortening in the Pyrenees and inversion of the Iberian and Catalan Coast Ranges terminated. Thereafter, convergence between Africa and Europe was exclusively compensated for by activity along the Betic-Balearic subduction system (Roca, 2001). Late Oligocene and early Miocene back-arc rifting in the Gulf of Lions and Valencia Trough caused uplift of the eastern parts of the Ebro Basin. Erosional breaching of the Catalan Coast Ranges was followed by deep truncation of the sedimentary fill of the Ebro Basin and the accumulation of erosion products in deltaic complexes that prograded from Serravallian times onwards into the Valencia Trough; this contributed to unflexing of the Iberian foreland lithosphere (Gaspar-Escribano et al., 2001).

\subsubsection{West Alpine Foreland}

By Middle Jurassic times, the area of the future West Alpine pro-wedge foreland (Fig. 20) was characterized by a wide shelf that was superimposed on a system of Triassic to Middle Jurassic half-grabens and horsts which had evolved prior to the opening of the Piemont-Penninic Ocean (Baudrimont and Dubois, 1977; Lemoine and de Graciansky, 1988; Razin et al., 1996). This shelf was further destabilized by Oxfordian-Aptian rifting that preceded the opening of the North Atlantic, Bay of Biscay and the Valais Trough, resulting in isolation of the Ibero-Briançonnais terrane (Stampfli, 1993; Philippe et al., 1998).

Starting in Campanian times, compressional stresses were exerted on the West Alpine passive margin in conjunction with convergence of the Apulian block with the continental Briançonnais terrain and the early phases of the Pyrenean orogeny (Roure and Colletta, 1996; Stampfli et al., 1998; Philippe et al., 1998). During the Paleocene, this margin was uplifted, as evidenced by the development of a regional unconformity (Philippe et al., 1998; Beck et al., 1998); this was accompanied by upthrusting of a basement block in the Pelvoux Massif (Ford, 1996). Although interpreted as reflecting the development of a flexural forebulge (Crampton and Allan, 1995), this deformation was more likely controlled by a combination of compressional stresses transmitted into the foreland crust from the Alpine collision front through the oceanic crust of the Valais Trough and from the Pyrenean orogen. By middle Eocene times, the West Alpine orogenic wedge had obliquely collided with the European margin, as indicated by the development of a flexural foreland basin that continued to evolve during the Oligocene. During this time span, the Bresse, Valence, Limagne and Gulf of Lions rift system came into evidence to the west of the evolving foreland basin (Sissingh, 2001). Starting in early Oligocene times, gradually increasing mechanical coupling between the West Alpine Orogen and its foreland at lithospheric levels, which can be attributed to the development of the Apulian Ivrea Zone mantle back-stop, caused imbrication of the foreland crust, progressive uplift of the external massifs and thrust-propagation into the foreland, inducing inversion of its Mesozoic extensional basins (Fig. 22) (Schmid and Kissling, 2000). By this process, the earlier 

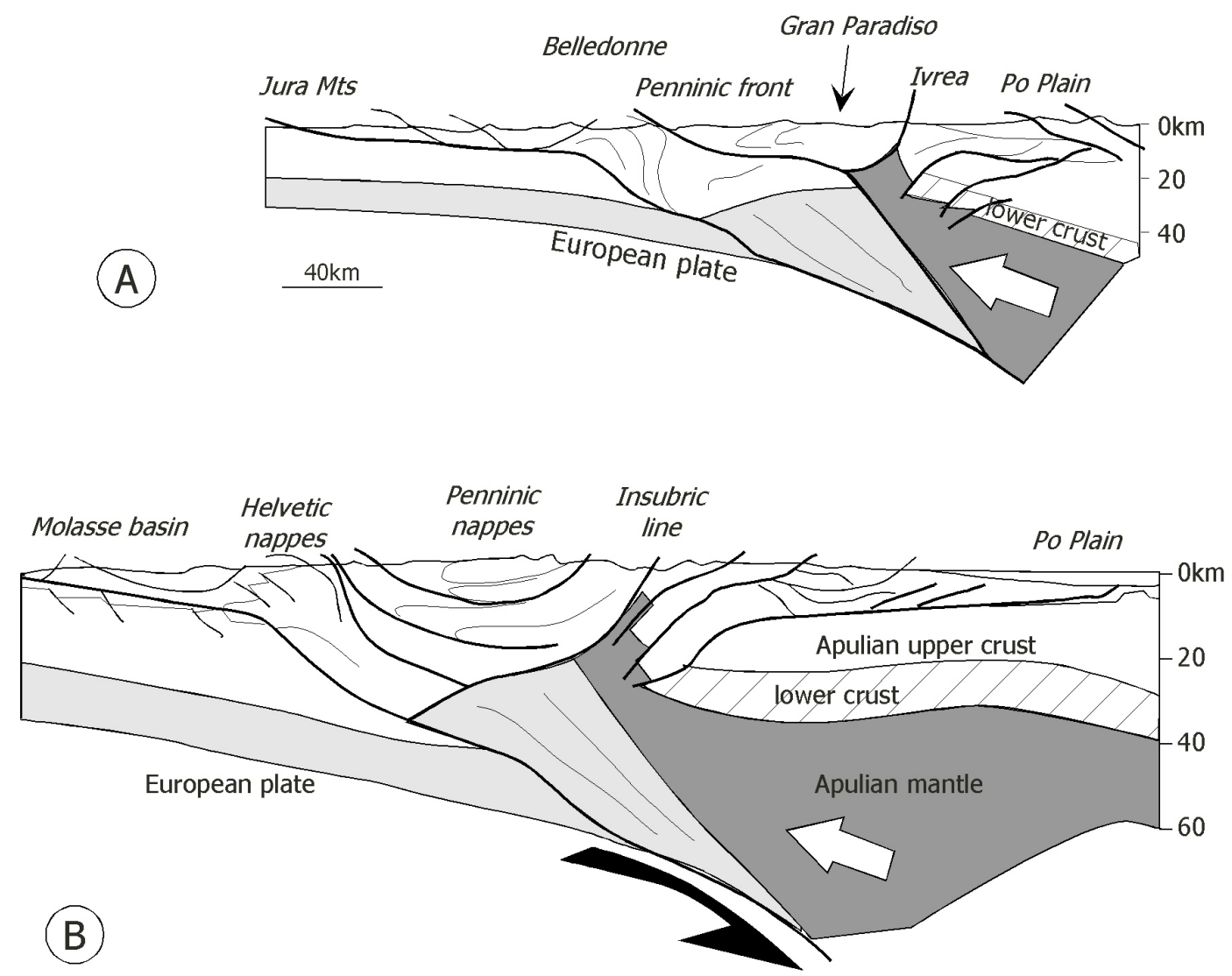

Fig. 22. Schematic crustal sections through the Western (a) and Central Alps (b). Light grey: European lower crust, dark grey: Apulian mantle (after Ziegler and Roure, 1996).

formed flexural foreland basin was largely destroyed (Roure and Colletta, 1996; Ziegler and Roure, 1996; Beck et al., 1998; Lickorish and Ford, 1998). Moreover, these foreland stresses impeded the evolution of the Cenozoic rift system (Ziegler, 1994; Sissingh, 2001). Contemporaneous inversion of Mesozoic rifts in the Celtic Sea and Western Approaches area (Fig. 23) can be related to far-field stresses that were transmitted from the Alpine collision zone into the European foreland at crustal and possibly mantle-lithospheric levels (Ziegler, 1990; Ziegler et al., 1995).

Middle Miocene and Pliocene uplift of the Massif Central, accompanied by widespread volcanic activity, may have been controlled by a combination of stress-induced lithospheric folding and mantle plume activity, with the former apparently governing its neotectonic deformation (Sobolev et al., 1997; Müller et al., 1997; Sissingh, 2001).

\subsubsection{Central Alpine Foreland}

In the northern, pro-wedge foreland of the Central Alps (Fig. 20), the regional unconformity that separates the deeply truncated Mesozoic series of the Helvetic Shelf from the Cenozoic sedimentary fill of the Molasse Basin has been attributed to the development of a flexural forebulge by Crampton and Allen (1995) and Burkhard and Sommaruga (1998). Middle-late Miocene uplift of the Massive Central, Vosges-
Black Forest and Bohemian Massif arches was also attributed to forebulge development by Laubscher $(1987,1992)$. However, these interpretations are difficult to reconcile with the evolution of the Alpine Orogen and its northern foreland.

The base-Tertiary unconformity of the Helvetic Shelf and the adjacent area of the future Molasse Basin developed during the latest Cretaceous and Paleocene, by which time the large South Penninic Ocean was closed and the Austroalpine orogenic wedge began to collide with the southern flank of the Middle Penninic continental Briançonnais terrane. The latter was still separated from the Helvetic shelf margin by the oceanic North Penninic Valais Trough (Schmid et al., 1996; Ziegler et al., 1996; Stampfli and Marchant, 1997; Stampfli et al., 1998, 2001). Presumably, initial subduction resistance of the Briançonnais block resulted in the buildup of compressional stresses that propagated through the oceanic crust of the Valais Trough into the Helvetic Shelf, inducing its folding, uplift and erosional truncation (Ziegler et al., 1998). This is supported by the irregular subcrop pattern of Mesozoic series that were locally truncated to Oxfordian levels (Hauber, 1961; Büchi and Schlanke, 1977; Crampton and Allen, 1995), as well as by faulting, involving uplift and erosion of basement rocks (Mayoraz, 1995; Burkhard and Sommaruga, 1998). Moreover, this interpretation is compatible with the far-field compression-induced 


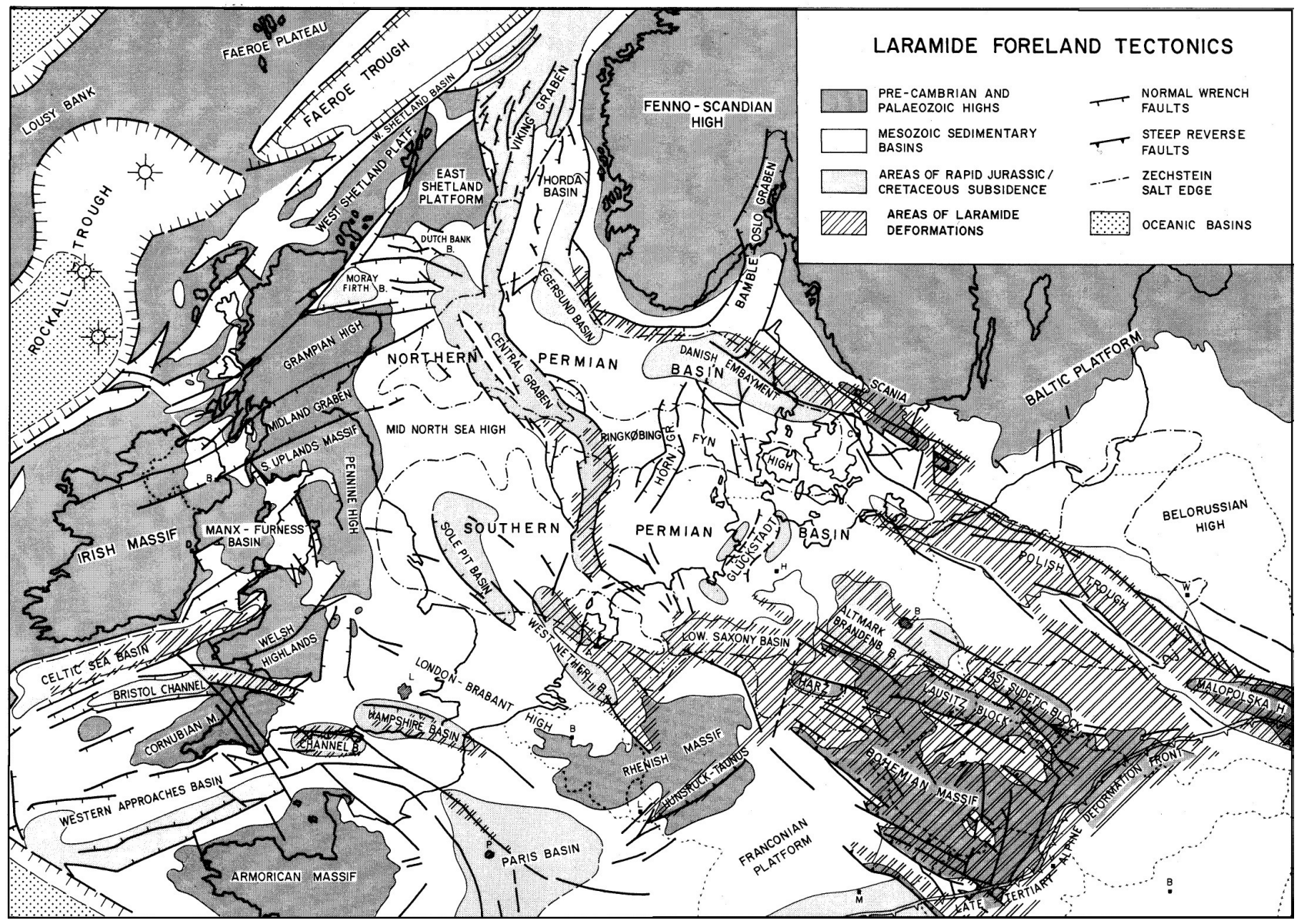

Fig. 23. Paleocene compressional foreland deformation of Western and Central Europe (after Ziegler, 1990).

inversion of Mesozoic extensional basins in Northern Germany, the Netherlands and the North Sea (Fig. 23) (Ziegler, 1990; Ziegler et al., 1995). In view of this, the forebulge hypothesis for the development of the base-Tertiary unconformity on the Helvetic Shelf has to be rejected.

Following activation of a subduction zone along the northern margin of the Briançonnais terrane (Stampfli et al., 1998) and subduction of the Briançonnais block and the Valais Ocean (Schmid et al., 1996; Ziegler et al., 1996), thrust loading of the Helvetic Shelf commenced during the late Eocene (Sissingh, 1998). This was accompanied by the development of bending stress-related normal faults (Herb, 1988; Menkveld-Gfeller, 1995). By now, sediment subduction presumably accounted for mechanical decoupling of the evolving Alpine Orogen and the Helvetic Shelf, as indicated by the absence of further inversion structures in the foreland. During the Oligocene, the evolving foreland basin subsided rapidly and expanded northward, receiving the detritus of the rising Alps. With the early Oligocene detachment of the Alpine subduction slab, a mantle backstop developed and, in conjunction with continued convergence, compressional stresses began to build up in the pro-wedge foreland, resulting in the imbrication of its crust and the progressive uplift of the Gotthard and later of the Aar massifs and the
Tauern window from Late Oligocene times onwards (Fig. 22; Schmid et al., 1996; Lammerer and Weger, 1998). On the other hand, imbrication of South Alpine retro-wedge basement commenced during the Late Cretaceous, was interrupted during late Campanian to Eocene times, resumed during the Oligocene and persisted until the end of the Tortonian (Schmid et al., 1996; Ziegler et al., 1996). This reflects increasing collisional coupling of the Alpine Orogen with its pro- and retro-wedge forelands at lithospheric levels, involving wedging of the Apulian lithosphere into the European one at a mid-crustal level (Schmid and Kissling, 2000). Middle Miocene to Pliocene crustal shortening resulted in further uplift of the Aar Massif and, during the late Serravallian, in thrust-propagation into the pro-wedge foreland, controlling folding of the essentially thin-skinned Jura Mtns. (Fig. 22) (Laubscher, 1987, 1992; Philippe et al., 1996; Burkhard and Sommaruga, 1998). In the process of this, the Swiss Molasse Basin was uplifted and partially destroyed by erosion. Late folding phases of the Jura Mtns., which apparently persist until the present, as indicated by geodetic data and intracrustal earthquake activity, involved the partial inversion of Permo-Carboniferous extensional basins underlying the Molasse Basin and the Jura Mtns. This suggests activation of an intra-crustal detachment horizon that is rooted at the front of 


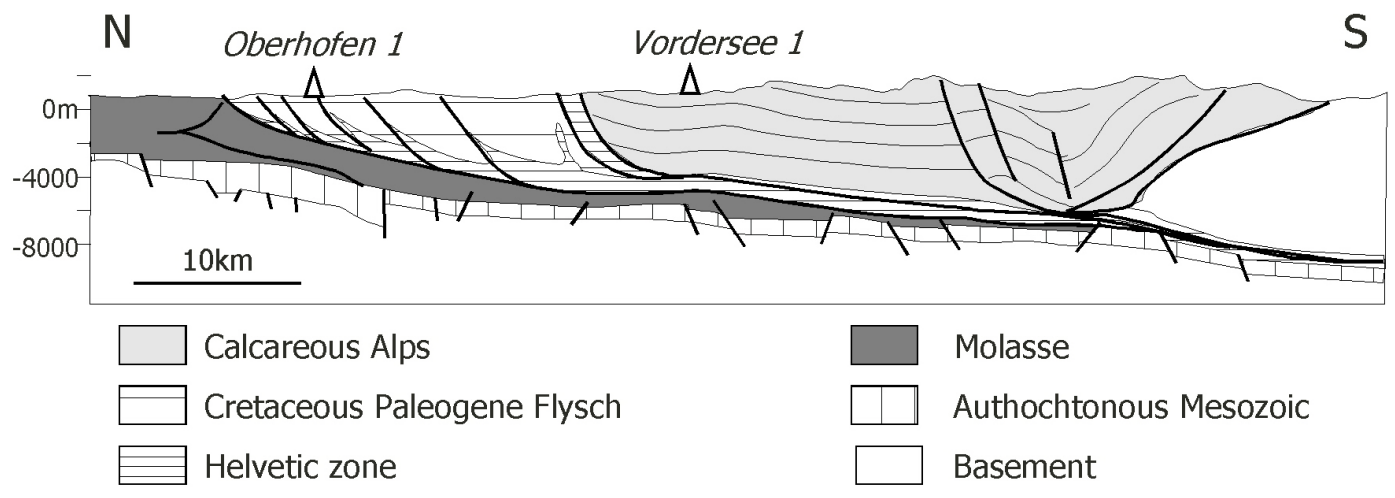

Fig. 24. Structural cross-section through the western parts of the Upper Austrian Molasse Basin and the Kalkalpen (near city of Salzburg; after Kollmann and Malzer, 1980; Zimmer and Wessely, 1996).

the Aar Massif (Ziegler et al., 1996).

Uplift of the Vosges-Black Forest and the Massif Central arches, which are both transected by elements of the Cenozoic European rift system, commenced some $15 \mathrm{My}$ ago and was accompanied by volcanic activity. This was followed around $13 \mathrm{Ma}$ by the onset of the Jura folding (Laubscher, 1987, 1992; Sissingh, 1998, 2001). By contrast, uplift of the Bohemian Massif, that is transected by the volcanic Eger rift, commenced only during the Pliocene (Ziegler, 1994). The crustal and lithospheric configuration of the Massif Central, the Burgundy transfer zone and the Vosges-Black Forest area (Prodehl et al., 1995; Lefort and Agarwal, 1996) suggests that lithospheric folding contributed significantly to the development of this system of arches. This concept is compatible with strong mechanical coupling of the Alpine Orogen with its northern foreland at lithospheric levels, as evidenced by its present stress regime (Müller et al., 1997) and the by Plio-Pleistocene accelerated subsidence of the North Sea Basin, which is also attributed to lithospheric folding (van Wees and Cloetingh, 1996). In view of this, it is unlikely that uplift of the Massif Central, Vosges-Black Forest and Bohemian Massif arches can be attributed to the development of a purely flexural forebulge.

\subsubsection{East Alpine-North Carpathian Foreland}

The eastward termination of the continental Mid-Penninic Briançonnais terrane (Stampfli et al., 1998, 2001) means that the evolution of the northern foreland of the Eastern Alps and North Carpathians differs considerably from that of the Central Alps.

During the Turonian closure of the eastern Penninic Ocean, pre-collisional compressional stresses began to be exerted onto the European passive margin, as evidenced by the onset of intraplate compressional deformation in the domain of the Bohemian Massif and the Polish Trough. During the Senonian this stress build-up continued intermittently and culminated during the Paleocene in intense deformation of the European Shelf, involving upthrusting of a Rocky Mountain-type array of basement blocks in the Bohemian
Massif and the inversion of the extensional Polish Trough and of Mesozoic transtensional basins along the northern margin of the Bohemian Massif (Fig. 23) (Ziegler, 1990; Ziegler et al., 1995).

Although exact dating of the collision of the Austro Alpine-North Carpathian orogenic wedge with the European passive margin is uncertain, it probably occurred during the late Senonian-Paleocene (Kovac et al., 1993). During this collisional phase, the European crust presented apparently major subduction resistance, as evidenced by its intense deformation and the resulting destruction of its Mesozoic sedimentary cover. Subsurface data show that this deformation extends deeply beneath the nappes of the northern Carpathians and the Eastern Alps. Considering that the European foreland crust extends some $150 \mathrm{~km}$ beneath the Eastern Alps (Tari, 1996), the most distal Paleocene intraplate compressional structures occurred about $1500 \mathrm{~km}$ to the northwest of the contemporaneous East-Alpine-Carpathian orogenic front (Fig. 23) (Ziegler, 1990; Ziegler et al., 1995, 1998).

Thrust- and slab-loaded subsidence of the East AlpineNorth Carpathian foreland basin commenced during the Eocene and persisted into the Miocene. Transgressive late Paleocene and Eocene series initially infilled the remnant erosional topography of the Paleocene inversion structures (Nachtmann and Wagner, 1987), such as deep canyons in Czechia (Brzobohaty et al., 1996). During the late Eocene, a rather ill-defined gentle swell partly separated the southern deeper-water basin from the northern shallow shelf of the East-Alpine foreland basin (Wagner, 1996, his Fig. 9c). Whether this should be interpreted as a flexural forebulge or as related to the topography of the Paleocene unconformity, remains an open question. Oligocene to early Miocene progressive obduction of the East-Alpine and North Carpathian nappe systems was accompanied by accelerated subsidence of the foreland basin and the development of a system of basin-parallel antithetic and synthetic normal faults with heaves of some $200 \mathrm{~m}$ (Fig. 24). Activity along these faults became northwards progressively younger in tandem with the progressive northward shift of the basin axis and broad overstepping of the northern basin margin (Bachmann et al., 


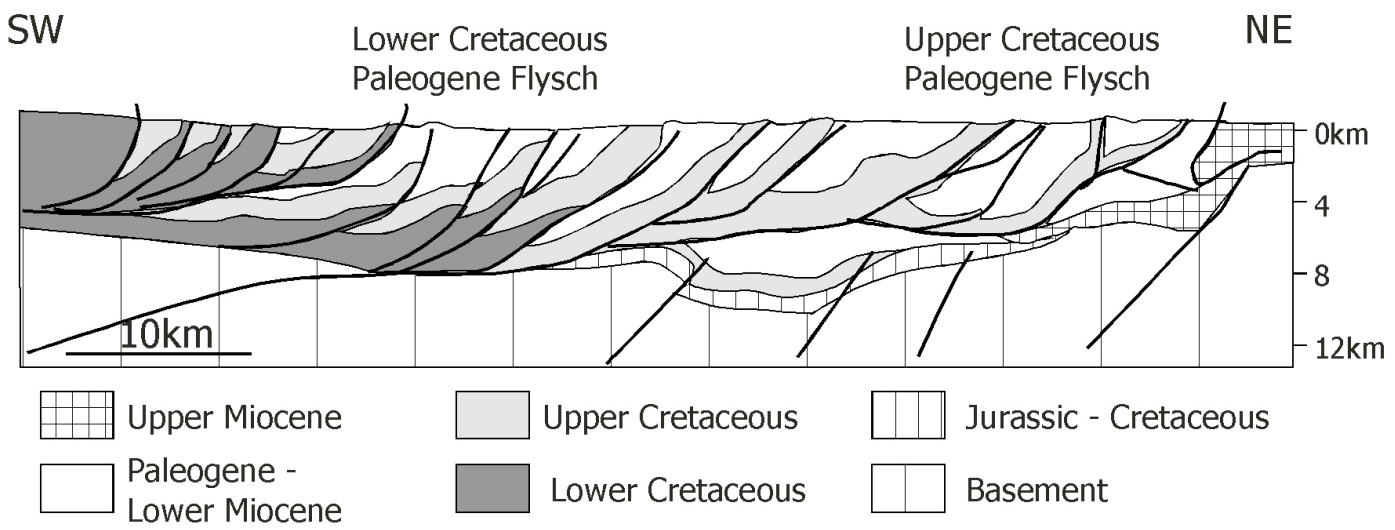

Fig. 25. Structural cross-section through the Ukrainian Carpathians (after Ellouz and Roca, 1994).

1987; Nachtmann and Wagner, 1987; Bessereau et al., 1996; Roeder and Bachmann, 1996; Slaczka, 1996; Wagner, 1996, 1998; Zimmer and Wessely, 1996).

Significantly, there is no evidence of Eocene to Miocene compressional intraplate deformations in the foreland of the Eastern Alps and the North Carpathians (Ziegler, 1990). This indicates that during the emplacement of their nappe systems these orogenic wedges were mechanically decoupled from their foreland (Ziegler et al., 1995, 1998). Moreover, during the Oligocene and Miocene evolution of the East AlpineCarpathian foreland basin, the Bohemian Massif, that was transected by the volcanic Eger Graben, was not significantly uplifted. This is born out by the transgression of midMiocene marine series along incised valley systems deep into the south-eastern parts of the Bohemian Massif (Steininger et al., 1989; Ziegler, 1990).

Whereas east of the Tauern window (Lammerer and Weger, 1998) the European foreland crust is not imbricated beneath the Eastern Alps (Tari, 1996), it appears to be imbricated beneath the outer Carpathians (Bessereau et al., 1996; Zoetemeijer et al., 1999). While the timing of these structures is uncertain, there is evidence of late compressional reactivation of some syn-flexural normal faults in the Upper Austrian Molasse Basin (Wagner, 1996, 1998; Gunzenhauser et al., 1997). This suggest that collisional coupling between the orogenic wedge and its foreland gradually increased at crustal and mantle-lithospheric levels, presumably during the late Mio-Pliocene. During the Plio-Pleistocene the Bohemian Massif was significantly uplifted; this was accompanied by further volcanic activity (Ziegler, 1990). Similar to the Vosges-Black Forest arch, uplift of the Bohemian Massif probably reflects lithospheric folding in response to the build-up of the present compressional stress regime.

Post-orogenic uplift of the East Alpine-North Carpathian foreland basin commenced during the late Miocene. Its northern margin was only moderately eroded during the PlioPleistocene uplift of the Bohemian Massif Arch. The width of the East Alpine-Carpathian foreland basin, which in late Eocene times was some $150 \mathrm{~km}$ wider (Roeder and Bachmann, 1996; Wagner, 1996), varies now between $200 \mathrm{~km}$ in southern Germany to $10-30 \mathrm{~km}$ in areas adjacent to the Bohemian Massif and about $75 \mathrm{~km}$ in southern Poland. This suggests that the Paleocene inversion-induced relief of the Bohemian Massif strongly influenced the geometry of the northern parts of this basin.

\subsubsection{East Carpathian Foreland}

Evolution of the East Carpathian foreland basin (Fig. 20) commenced only during the late Palaeogene-early Neogene with the collision of a flysch-dominated accretionary wedge with the European foreland (Ellouz and Roca, 1994). However, pre-collisional build-up of intraplate compressional stresses during the progressive closure of the oceanic intraCarpathian Magura-Piennide Basin is held responsible for the Paleocene partial inversion of the Mesozoic shelf in the Ukraine (Sovchik and Vul, 1996), located in the prolongation of the Polish Trough (Ziegler and Roure, 1996). On the other hand, Early and Middle Cretaceous inversion of the Dobrogea Trough, that extends north-westwards beneath the outer Carpathians, reflects the build-up of far field compressional stresses during the evolution of the Balkanides (Seghedi, 2001; Georgiev et al., 2001).

During the Oligocene to late Miocene emplacement of the Carpathian nappes on the European foreland, the latter subsided rapidly. This was accompanied by the activation of an array of essentially synthetic flexural faults (Dicea, 1995, 1996; Matenco and Bertotti, 2000). Particularly in the area of the Ukrainian Carpathians, reactivation of presumably Mesozoic fault systems accounted for strain concentration on a small number of major faults with throws of up to $2.5 \mathrm{~km}$ (Fig. 25) (Ellouz and Roca, 1994; Izotova and Popadyuk, 1996; Sovchik and Vul, 1996). Geophysical data show that the European foreland crust extends up to $75 \mathrm{~km}$ beneath the Carpathian nappes before it is imbricated, forming deepseated antiform structures (Dicea, 1996; Sovchik and Vul, 1996; Stefanescu and Baltes, 1996). In the foreland of the East Carpathians, there is no evidence for a flexural forebulge nor for young intraplate compressional structures. The remnant East Carpathian foreland basin ranges in width between 10 and $40 \mathrm{~km}$ and widens out to the south to some $100 \mathrm{~km}$ in 
$S$

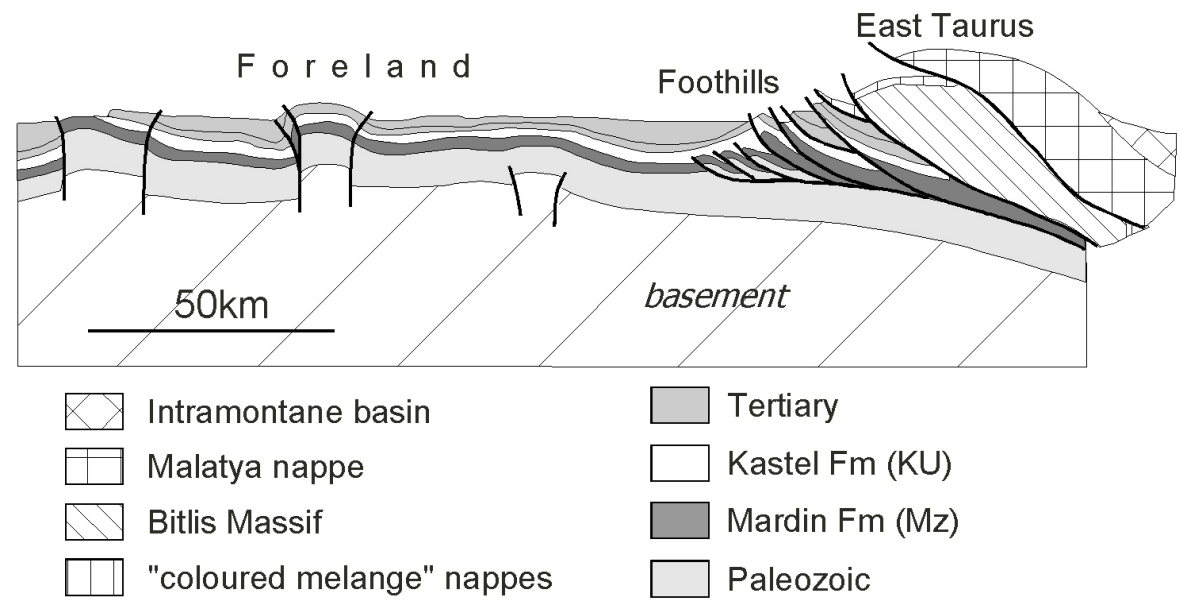

Fig. 26. Schematic cross-section through Taurus pro-wedge foreland basin (modified after Gilmour and Mäkel, 1996).

the Romanian Focsani Basin. Rapid late Pliocene to Recent subsidence of this basin is apparently governed by the nearly vertically dipping Vrancia slab which consists of continental mantle-lithosphere that was partly delaminated from the European foreland (Chalot-Prat and Girbacea, 2000).

\subsubsection{East Taurus foreland}

Evolution of the Taurus Orogen (Figs. 20 and 26) commenced with the Mid-Cretaceous activation of an intraoceanic arc-trench system in the Neotethys (Stampfli et al., 2001). This arc collided during the early Senonian with the northern passive margin of Arabia, as evidenced by the emplacement of an ophiolite nappe, the subsidence of a prowedge foreland basins and uplift of a distal potential forebulge that was followed by imbrication of the passive margin sedimentary prism. These thrust sheets were sealed by Maastrichtian-Paleocene marine series (Gilmour and Mäkel, 1996). During the Eocene, out-of-sequence thrusting resumed and persisted into the Miocene in conjunction with emplacement of the basement-cored Taurus nappes (Yilmaz, 1993).

Already during the Coniacian-Santonian, collision-related far-field compressional stresses induced a first phase of inversion of the Permo-Carboniferous northeast striking Palmyra Trough of Syria and the Lebanon. During the Coniacian to Campanian, the north-westerly striking Euphrates graben of Syria came into evidence. This was followed by the late Eocene to Miocene main inversion of the Palmyra Trough (Salel and Séguret, 1994; Sawaf et al., 2001; Walley, 2001). At the same time the remnant foreland basin of the Taurides was disrupted by the upthrusting of an array of basement blocks (Fig. 26) (Gilmour and Mäkel, 1986).

The evolution of the Taurus pro-wedge foreland reflects its intermittent, though strong mechanical coupling with the Taurus Orogen at lithospheric levels.

\subsubsection{Po Plain-Adriatic foreland basin}

The Po Plain-Adriatic foreland basin is superimposed on the stable continental Apulia block that is characterized by thick Mesozoic platform and basinal series. At present this platform is almost entirely surrounded by thrust belts and related foredeeps, albeit of different depth, extent and age (Fig. 20) (Doglioni, 1993). The Po Plain foreland basin is rimmed to the west and north by the Alps and to the south by the Apennine. To the southeast it opens into the Adriatic Basin which is delimited to the southwest by the Apennines and to the northeast by the Dinarides and Albanides. To the south, the Adriatic Basin opens into the oceanic Ionian Sea, a remnant of Neotethys.

During the Late Jurassic and Early Cretaceous the Apulian Platform formed part of the larger Dinaric-Hellenic continent that was fringed by the Neotethys, Maliak-Vardar and Alpine Tethys (Penninic) oceans (Stampfli et al., 2001).

Following closure of the Vardar Ocean, the northeastern margin of the Apulian Platform became thrust-loaded by the Dinarides orogenic wedge during the latest Cretaceous. This was accompanied by the development of a pro-wedge flexural foreland basin. Thrusting and nappe emplacement continued until the Oligocene. During the Eocene-Oligocene, thin-skinned thrusts, involving a thick carbonate-dominated sequence, propagated far into the foreland, destroying the pre-existing Dinarides foreland basin (Pamic et al., 1998). In the Albanides, thin-skinned thrusting and development of a pro-wedge flexural foreland basin also commenced during the latest Cretaceous-Paleogene and persisted until early mid-Miocene times; following an interruption, thrusting and foreland basin subsidence resumed during the Pleistocene (Frasheri et al., 1996; Velaj et al., 1999; Robertson and Shallo, 2000).

In conjunction with the evolution of the Central Alps, back-thrusting and loading of the northern parts of the Apulian Platform commenced during the late Cenomanian and 

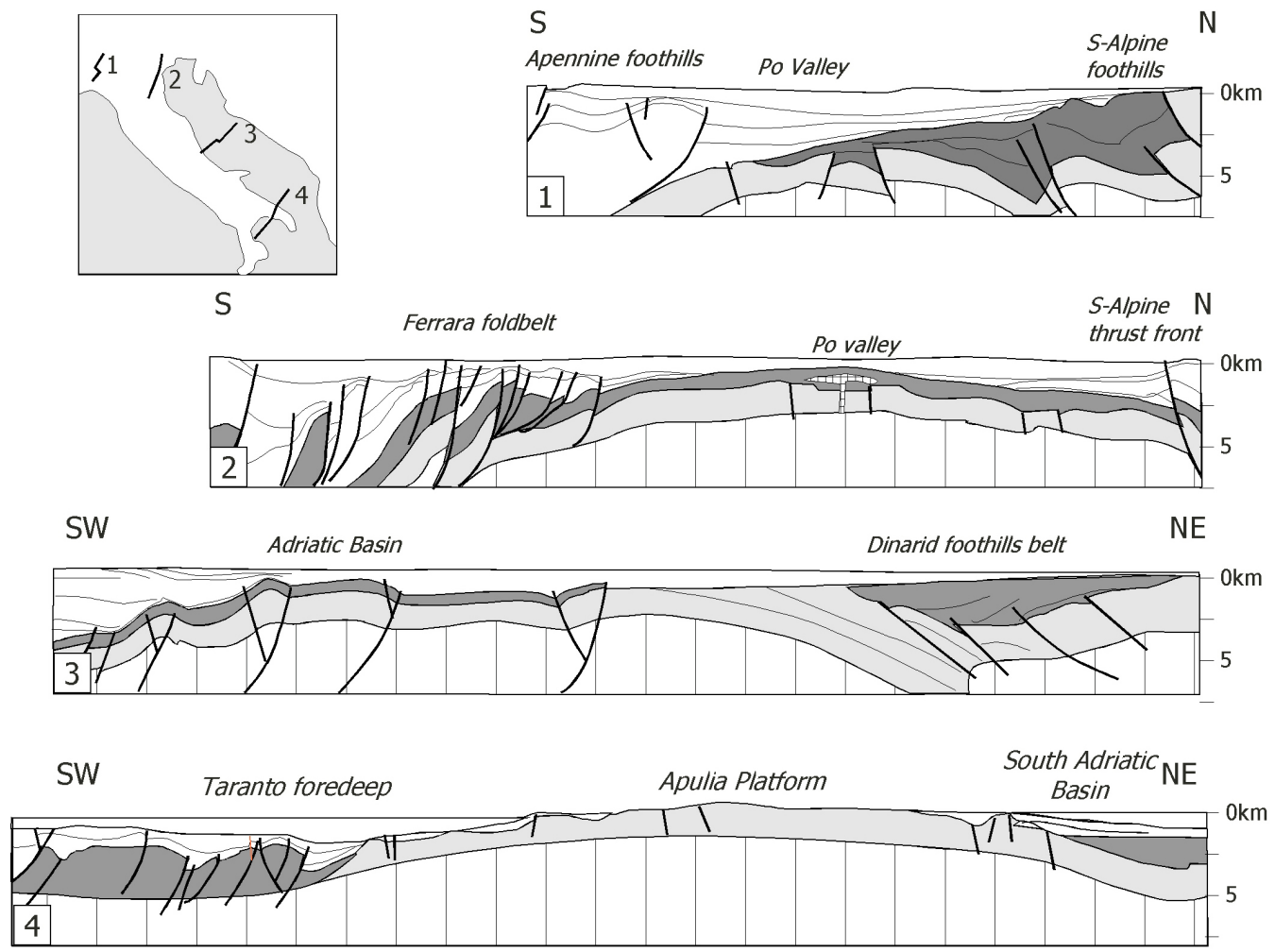

Post-Messinian

Pre-Messinian Tertiary

Mesozoic $\square \square$ undifferentiated basement

Fig. 27. Schematic cross-sections through the Po Plain and Adria pro-wedge foreland basin of the Apennines and Dinarides and the retrowedge foreland basin of the South Alps (after Ziegler, 1988).

persisted intermittently until the Tortonian, and in part until the present. During the Oligocene and middle Miocene, development of a thick clastic prism testifies to the subsidence of a retro-wedge flexural foreland basin (Bertotti et al., 1998). However, during the late Miocene this basin was largely destroyed by thrust propagation into the foreland. The internal, northern parts of the Southern Alps are characterized by stacked basement-involving thrust sheets whereas their external, southern parts are thin-skinned. In the Lombardy sector, these thrusts are sealed by Messinian deposits while in the Veneto sector the thrust front is still active (Figs. 22 and 27) (Roeder and Lindsay, 1992; Anelli et al., 1996; Ziegler et al., 1996).

Evolution of the Apennines commenced with the latest Cretaceous-Paleocene activation of the Balearic subduction system that dipped north-westwards beneath the Iberian plate, controlling the progressive closure of the Alpine Tethys and opening of the Algero-Provençal back-arc basin (Gueguen et al., 1998; Séranne, 1999; Zeck, 1999; Roca, 2001). As evidenced by the onset of flysch sedimentation, thrust-loaded subsidence of the western margin of the Apulian Platform commenced in the northern Apennine during the late Oligocene and during the middle Miocene in the southern Apennine. Thrusting and progressive imbrication of the sedimentary cover of the Apulian Platform, which persists until the mid-Pleistocene, went hand in hand with the development of the Apennine pro-wedge foreland basin (Fig. 27) (Anelli et al., 1996).

During late Oligocene to late Miocene times, the Po Plain developed as a double-loaded foreland basin, forming the pro-wedge basin of the Apennine and the retro-wedge basin of the Alps (Fig. 27). Strong collisional coupling of both orogenic wedges at crustal levels with their common foreland is indicated by the propagation of basement-cored thrust sheets deep into the Po Basin, as well as by basement-involving inversion of Mesozoic extensional features within it (Cassano et al., 1986). In view of this, the gentle base Pliocene arch that is observed in the eastern part of the Po Plain, which coincides with the site of Oligocene alkaline volcanism, may be rather attributed to lithospheric folding than to the development of a flexural forebulge, as postulated by Royden (1988) (see also Bertotti et al., 1998).

In the northern and central Adriatic domain, flysch sedimentation commenced only after the Messinian. As by this time the Dinarides were inactive, this basin evolved only in response to Apennine thrust and slab loading. However, its Plio-Pleistocene development was accompanied by the propagation of deep-seated, possibly basement-involving thrusts into the foreland, exerting a strong control on its subsidence pattern and the facies development of its clastic fill. By con- 


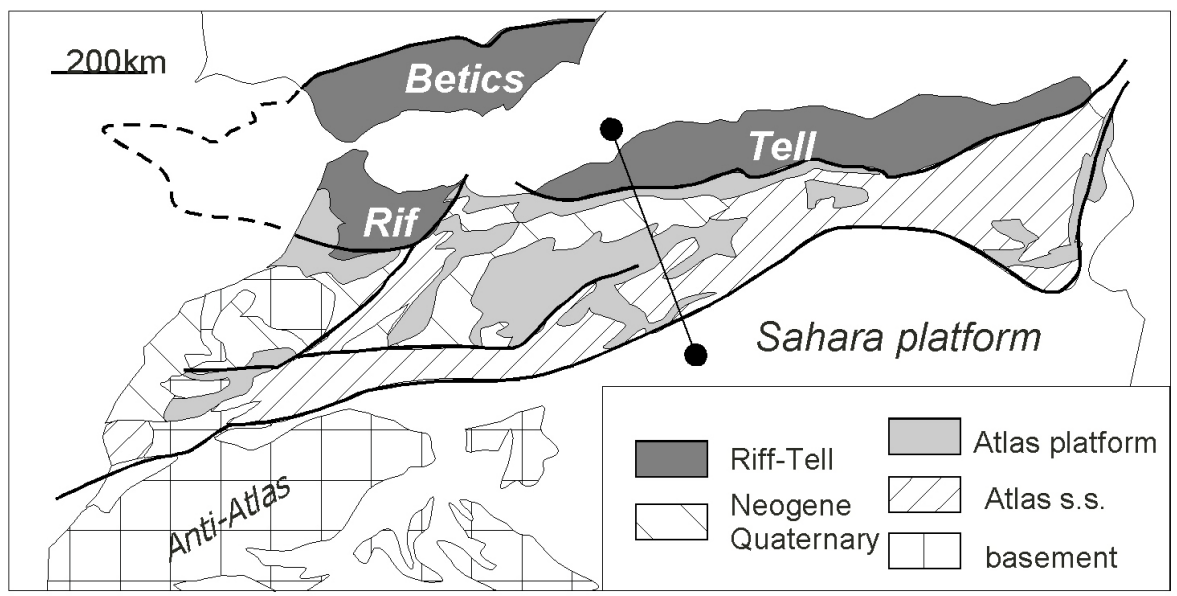

$\mathrm{N}$

$S$

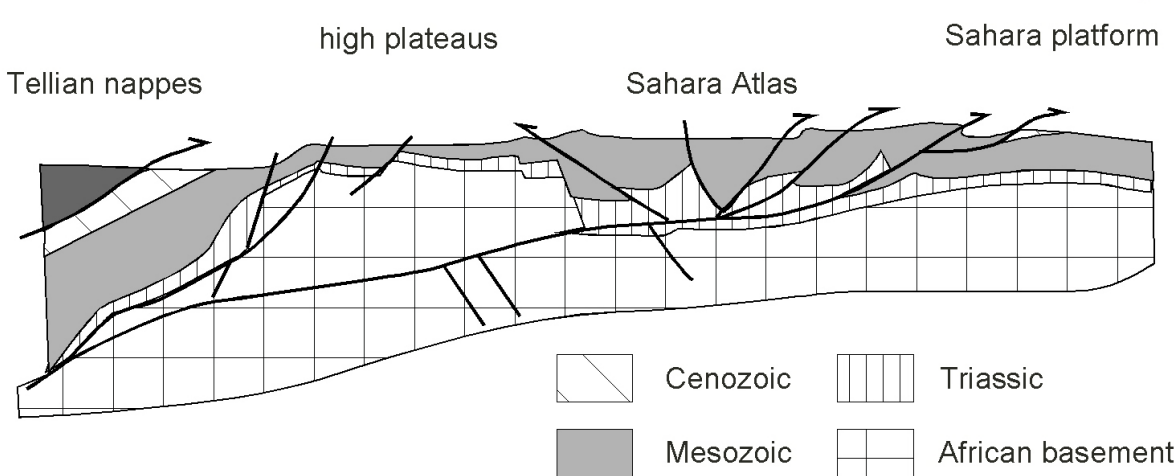

Fig. 28. Tectonic framework of Rif-Tell Orogen and Atlas System in the pro-wedge foreland of northwestern Africa and schematic crustal cross-section (after Frizon de Lamotte et al., 2000).

trast, the evolution of the southern parts of the Apennine foreland was controlled by thrust loading by the Apennine and the Albanides (Anelli et al., 1996). Seismic tomographic studies suggest that beneath the Apennine the subducted slab is detached from the foreland lithosphere, whereas it may still be attached to it in the domain of the Calabrian arc (Wortel and Spakman, 1992; de Boorder et al., 1998; Lucente and Soeranza, 2001). This concept is compatible with the geochemical signature of magmatic activity in the internal parts of the Apennine (Wilson and Bianchini, 1999).

Whereas in the northern and central Adriatic the PlioPleistocene Apennine foreland basin is $3-7 \mathrm{~km}$ deep and $100-200 \mathrm{~km}$ wide, it narrows to $15-30 \mathrm{~km}$ in its southern parts where it is flanked by the Gargano-Puglia Arch (Apulian Platform, Fig. 27). This arch, which separates the narrow, steeply dipping southern Apennine foreland basin (Bradanic Trough) from the much wider Albanian foreland basin, is a unique feature in the Apennines foreland (Doglioni et al., 1994). Starting in early Pliocene times, the Gargano Platform, and in mid-Pleistocene times also the Puglia Arch, were uplifted (Bertotti et al., 1999). The western flank of this arch, corresponding to the Bradanic Trough, is marked by a system of normal and reverse faults, including ramp anticlines, pop-up structures and dextral transfer faults involving pre-Pliocene carbonates (Casnedi, 1988; Sella et al., 1990; Argnani et al., 1993; Doglioni et al., 1994). By contrast, its eastern flank is marked by partly major easthading normal faults (Anelli et al., 1996; Frasheri et al., 1996). Subsidence of the Bradanic Trough and associated uplift of the Gargano-Puglia Arch was interpreted by Royden (1988) in terms of flexural forebulge development. Yet, intense imbrication of the autochthonous basement and its sedimentary cover beneath the Apennine nappes (Mostardini and Merlini, 1986; Anelli et al., 1996; Noguera and Rea, 2000) suggests strong mechanical coupling between the orogenic wedge and its foreland at crustal levels. This may be an effect of increasing subduction resistance of the thick Puglian lithosphere, resulting in the build-up of compressional stresses within it, causing its buckling (Doglioni et al., 1994).

\subsubsection{Northwest African Maghrebian Foreland}

The structural configuration and evolution of the northwest African Maghrebian Orogen (Rif and Tell thrust belts) and its foreland is summarized in Fig. 28 and 29. During the Triassic and Early Jurassic, the future foreland of the Maghrebian Orogen was transected by the Tunesian Trough and the Sahara, High and Middle Atlas rifts (Vially et al., 1994). 
NNW SSE
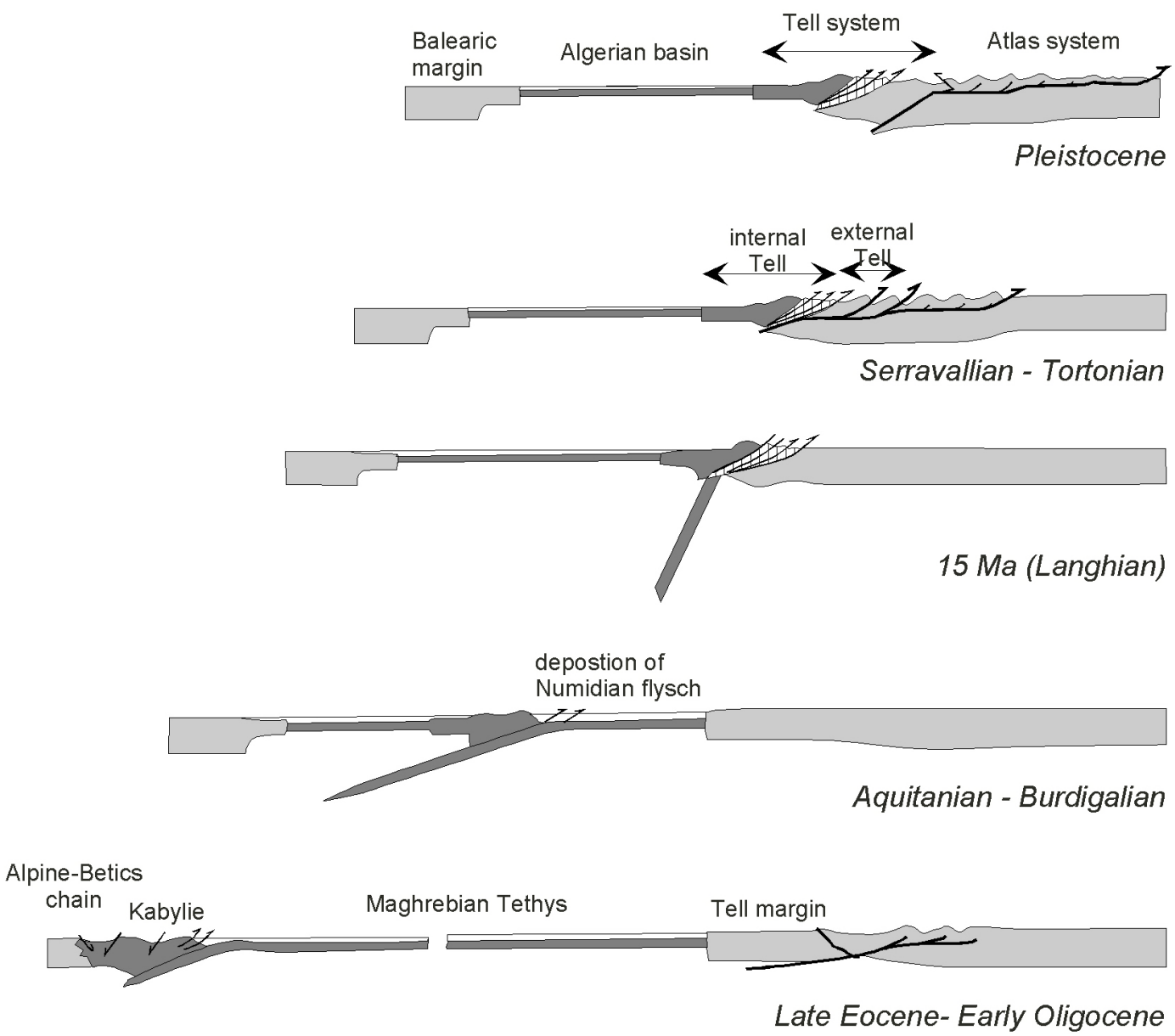

$100 \mathrm{~km}$

Fig. 29. Evolution of Tell-Atlas system (after Frizon de Lamotte et al., 2000).

These became inactive with the Middle Jurassic opening of the Alpine Tethys (Ziegler, 1988; Stampfli et al., 1998, 2001). Closure of the West Mediterranean segment of the Alpine (Maghrebian) Tethys began with the latest Cretaceous to Paleocene development of a northwest-dipping subduction zone along the Betic-Balearic margin of the Iberian plate (Séranne, 1999; Vergés and Sabat, 1999; Zeck, 1999; Roca, 2001; Vera, 2001).

First minor inversions of the Atlas rift systems occurred at the end of the Cretaceous, probably in response to compressional stresses related to the convergence of Africa with Europe. These were also responsible for the activation of the Betic-Balearic subduction system along the conjugate Iberian margin. The second, middle to late Eocene major inversion of the Atlas troughs (Vially et al., 1994; Zizi, 1996), that also affected the Early Palaeozoic Saoura-Ougarta rift (Fig. 10) (Ziegler, 1988), is related to the transmission of compressional stresses though the oceanic crust of the Maghrebian Tethys from the Balearic subduction zone, either due to an acceleration of subduction rates (Frizon de Lamotte et al., 2000) or to the arrival of an unspecified subduction obstacle in the respective trench (e.g. tranform ridge). Following late Oligocene and early Miocene back-arc extension, controlling the subsidence of the Valencia Trough and the Provençal Basin, the Alboran-Kabylia terrane was separated during the Burdigalian from the Balearic arc, resulting in opening of the oceanic Algerian Basin (Vergés and Sabat, 1999; Roca, 2001). During progressive consumption of the remnant Maghrebian Tethys and contemporaneous opening of the Algerian Basin, no major stresses were exerted on the North African margin. By Langhian times, the AlboranKabylia terrane collided with the African margin, inducing the third deformation phase of the Atlas system, which persisted until the Pleistocene and involved imbrication of the African crust and inversion of the Mesozoic Atlas grabens. In the process of this, successive small pro-wedge foreland basins developed that were step-wise incorporated into the orogenic wedge. During the Pleistocene and early Quater- 
nary, the Rif-Tell orogenic system was inactive whilst continued crustal shortening was accommodated by the propagation of thick-skinned thrusts into the Atlas system, inducing its wholesale uplift and inversion of Mesozoic grabens (Bracène et al., 1998; Frizon de Lamotte et al., 2000).

Apparently, the African passive margin presented strong subduction resistance and could not be significantly overstepped by the Alboran-Kabylian orogenic wedge. This resulted in intense deformation of the pro-wedge foreland, involving the reactivation of pre-existing tensional crustal faults, thus impeding the development of a classical flexural foreland basin.

\section{Mechanisms related to the Interplay of Stress and Rheology}

The evolution of pro- and retro-wedge forelands depends essentially on the rheological properties of their lithosphere, which is strongly influenced by the presence or absence of pre-existing crustal discontinuities, as well as on the stresses that are exerted on it during the evolution of the encroaching orogenic wedge. These stresses include the vertical, downwards directed topographic (tectonic) load of the orogenic wedge, and for pro-wedge forelands also the downwards directed load of the subducted lithospheric slab, as well as tangential stress that can be projected into the foreland as a result its mechanical coupling with the respective orogenic wedge (Fig. 2).

5.1 Mechanisms controlling Foreland basin development and destruction

The width and depth of retro-wedge flexural foreland basins is controlled by the $\mathrm{T}_{\mathrm{e}}$ of the underthrusted continental lithosphere and the load exerted on it by the orogenic wedge. Conversely, the width and depth of pro-wedge basins is controlled by the $T_{\mathrm{e}}$ of the underthrusted lithosphere and a combination of the tectonic loads exerted on it by the orogenic wedge and the subducted lithospheric slab. The magnitude of the latter depends on the dip-angle, length and composition of the subducted lithospheric slab.

Whereas subduction slabs consisting of oceanic lithosphere can extend unbroken down to the core-mantle boundary (Grand et al., 1997; Bijwaard et al., 1998), continental lower crust and mantle-lithosphere can be subducted to depths of 100 to $150 \mathrm{~km}$, as indicated by the occurrence of high to ultra-high pressure metamorphic rocks in orogenic belts (Altherr and Kalt, 1996; Matte, 1998). However, at these depths and temperatures, the strength of subducted continental lithosphere apparently decreases to the point at which it can no longer support the load of the attached oceanic slab and fails. Depending on convergence rates and the thermal and rheological structure of the subducted continental lithosphere, the slab break-off point may be located at depths ranging between 80 and $150 \mathrm{~km}$, either within the subducted continental margin or in the adjacent un-stretched crust (Wong A Ton and Wortel, 1997). In this respect, it noteworthy that the composition of old continental mantle lithosphere can differ from that of oceanic lithosphere in so far as it can contain significant amounts of eclogitized crustal material (Ziegler et al., 1998).

In simplistic models, syn-orogenic detachment of the subducted lithospheric slab from the continental pro-wedge lithosphere may results in its un-flexing, uplift and increased mechanical coupling with the upper plate at mantlelithospheric levels (mantle back-stop; Fig. 22). However, as plate motions are not exclusively governed by slab pull forces (Ziegler et al., 1995), slab detachment does not automatically entail the end of orogenic activity (e.g. Central Alps, $120 \mathrm{~km}$ post slab detachment shortenig: Schmid et al., 1996; Ziegler et al., 1996). Under conditions of continued convergence after slab detachment, large compressional stresses can be transmitted into the pro- and retro-wedge forelands, inducing major intraplate compressional deformation (Ziegler et al., 1998).

The flexural response of foreland lithosphere to topographic and slab loads depends on its $\mathrm{T}_{\mathrm{e}}$ which is controlled by its rheological structure - largely a function of its thermal regime and the thickness of the continental crust. In the presence of thick continental crust, the upper part of the mantle-lithosphere may be weak, whereas in the presence of relatively thin continental crust the upper part of the mantlelithosphere is strong and contributes significantly to the $T_{e}$ of the lithosphere (Cloetingh and Burov, 1995).

Purely flexural forebulges can only develop when the orogenic wedge is mechanically decoupled from the underthrusted foreland lithosphere and the latter has a sufficient $\mathrm{T}_{\mathrm{e}}$ to transmit the loading forces into the foreland. However, when the orogenic wedge and the underthrusted foreland lithosphere are mechanical coupled, compressional stresses exerted on the latter can induce its folding, causing narrowing and deepening of the foreland basin and uplift of an outer arch (e.g. Bradanic Trough and Puglia Arch; Cloetingh et al., 1989; Peper et al., 1992, 1994; Zhang and Bott, 2000).

Flexural bending of a foreland lithosphere, depending on its intensity and radius, can be accompanied by the development of flexure-induced synthetic and antithetic extensional faults (e.g. German and Austrian Molasse Basin, Quebec Lowlands, Anadarko Basin, Patagonia).

Particularly in the presence of a thick crust and preexisting crustal-scale orogen-parallel faults, the $T_{e}$ of the continental lithosphere can be weakened to the degree that the loads of the orogenic wedge and the subducted slab are not fully transmitted into the foreland. This results in the development of a steep, narrow foreland basin, characterized by major synthetic syn-flexural normal faults (e.g. Ukrainian East Carpathians).

Flexural foreland basins can only fully develop when during the entire orogenic cycle no major compressional stresses are transmitted at crustal and/or mantle-lithospheric levels from the orogenic wedge into the foreland (e.g. Alaska North Slope, Alberta and Adriatic basins). However, in the presence of a thick pre-flexural sedimentary sequence (passive 

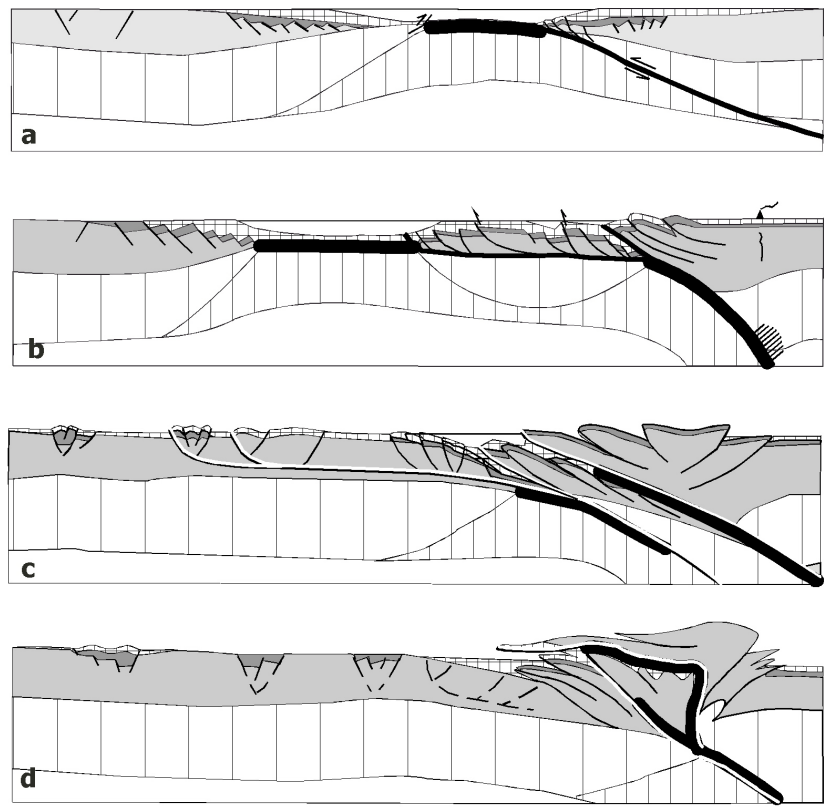

Fig. 30. Conceptual model for different scenarios of pro-wedge foreland compressional deformation, (a) during subduction initiation along one of the margins of an oceanic basin compressional stresses can be transmitted into the conjugate margin, (b) during subduction impediment, caused by the arrival of a microcontinent at an arc-trench system, compressional stresses may build-up of in the lower plate, causing subduction progradation and deformation of a distal passive margin, (c) during the initial collision of an orogenic wedge with a passive margin, subduction resistance of the latter causes the build-up of compressional stresses in the foreland, inducing intense intraplate deformation, (d) during over-thickening of a collisional belt, involving the development of a mantle backstop, compressional stresses build-up in its pro- and retro-wedge foreland. Legend same as Fig. 1 (after Ziegler et al., 1998).

margin prism), thin-skinned thrusts can propagate far into the foreland, causing partial or total destruction of a pre-existing flexural foreland basin (e.g. Dinarides, Mackenzie Mtns.). Generally this is not accompanied by the development of major secondary flexural foreland basins, presumably due to the relatively low density of the imbricated sediments and their relatively low topographic expression. On the other hand, subduction resistance of a pro-wedge continental foreland lithosphere during its initial collision with an orogenic wedge, can result in the transmission of mayor stresses into the foreland. These can induce activation of rheologically weak layers within or at the base of the crust, acting as detachment horizons, and intense deformation and partial to total destruction of the passive margin sedimentary prism (e.g. East Alpine-North Carpathian and Maghrebides forelands); this impedes the later development of a thin-skinned foreland fold-and-thrust belt.

Similarly, during stages of collisional over-thickening of an orogenic wedge, compressional stresses can be transmitted into its foreland at crustal and mantle-lithospheric levels, inducing its thick-skinned deformation, far-field inver- sion of pre-existing tensional basins and lithospheric folding (e.g. forelands of Central Alps, Eastern Taurus, Pyrenees).

\subsection{Scenarios for intraplate foreland compression}

Horizontal intraplate compressional stresses can be exerted on back-arc and retro-wedge foreland domains during convergence acceleration of the colliding plates and particularly during over-thickening of the orogenic wedge. Major syn-orogenic retro-wedge foreland compression controlled for instance the Paleogene development of the Rocky Mtns. and the Late Palaeozoic development of the Ancestral Rocky Mtns. Horizontal compressional stresses can be exerted on pro-wedge foreland domains under the following scenarios (Fig. 30) (Ziegler et al., 1998).

(1) During the initiation of a new subduction zone along one of the continental margins flanking a relatively old oceanic basin compressional stresses exerted on them can cause their deformation. However, once a subduction zone is activated along one of the two margins, the conjugate margin becomes tectonically inactive. Which of the two conjugate margins will be the locus of subduction initiation is controlled by their rheological structure and depends largely on their crustal configuration and the thickness of their sedimentary cover (Ziegler et al., 1998). Examples are compressional structures which developed in northwest Africa during the end-Cretaceous activation of the Balearic subduction system (Frizon de Lamotte et al., 2000) and on the slope of the Armorican Shelf during the Eocene development of the Cantabrian subduction zone (Masson et al., 1994).

(2) During periods of subduction impediment, caused by the arrival of more buoyant crustal material at a mature arc-trench system, such as an oceanic plateau, transform ridge, island arc or microcontinent. Subduction resistance of such crustal element can cause the build-up of compressional stresses in the lower plate (Mueller and Phillips, 1991; Coos, 1993). Depending on the size and rheological structure of such an subduction obstacle, its upper parts can either be sheared off and incorporated into the accretionary wedge (Lallemand et al., 1989), or a new subduction zone can develop along its distal, non-collisional margin. In either case, compressional stresses may be transmitted through a relatively old oceanic basin, separating the subduction obstacle from a passive margin, and cause deformation of the latter. However, once subduction of such an obstacle begins, or a new subduction zone is activated along its noncollisional margin, stresses in the lower plate will relax. An example of this is the Paleocene deformation of the Helvetic Shelf and the inversion of Mesozoic grabens in the Channel and North Sea area (Ziegler, 1990), which occurred during the collision of the Austroalpine orogenic wedge with the continental Briançonnais terrane (Stampfli, 1993). Similarly, the late Eocene inversion of 
Mesozoic and Palaeozoic grabens in northwest Africa (Frizon de Lamotte et al., 2000) may be related to a subduction obstacle arriving at the Balearic arc-trench system rather than to its activation.

(3) During the initial collision of an orogenic wedge with a passive margin, and depending on the subduction resistance of the latter, compressional stresses can be transmitted into a pro-wedge foreland, causing major intraplate compressional deformation. Once subduction of continental lithosphere commences, nappes are obducted on the passive margin and a flexural foreland basin develops. At this stage, mechanical coupling between the orogenic wedge and its foreland may either persist or cease. This is exemplified by the latest Cretaceous and Paleocene deformation of the East Alpine and North Carpathian foreland, prior to the Eocene development of a flexural foreland basin. Resulting structures include inversion of Mesozoic extensional basins and upthrusting of the Rocky Mtn.-type array of basement blocks forming the Bohemian Massif. During the Eocene to early Miocene emplacement of the East Alpine and North Carpathian nappes, the orogenic wedge and its foreland were apparently mechanically decoupled, as evidenced by the lack of further foreland compressional deformation (Ziegler, 1990; Ziegler et al., 1995).

(4) During post-collisional over-thickening of an orogenic wedge at high strain rates, and also in response to slab detachment and the development of a mantle back-stop, large stresses can be transmitted into pro- and retrowedge forelands (Beaumont et al., 1994; Roure et al., 1996). These can induce imbrication and detachment of the foreland continental crust at the level of the middle or lower crust, resulting in uplift of external massifs, as well as far-field intraplate deformation, including basin inversion and broad lithospheric folding. Examples are provided by the Oligocene and later evolution of the Western and Central Alps and their foreland, the Late Palaeozoic deformation of the Sahara Platform and the Uralian Timan-Pechora Province, the end Devonian uplift of the Boothia arch in the Inuitian foreland and the end Silurian lithospheric folding of the Caledonian forelands (Ziegler et al., 1998).

\subsection{Mechanical coupling of orogenic wedges and forelands}

The build-up of collision-related compressional intraplate stresses is indicative of mechanical coupling between an orogenic wedge and its pro- and/or retro-wedge foreland(s). Resulting crustal- and lithosphere-scale compressional deformations indicate mechanical coupling between an orogenic wedge and its foreland(s) at the level of the crust and the mantle-lithosphere, respectively. Spatial strength variations within the crust and mantle-lithosphere play an important role in the localisation of crustal- and lithospherescale deformation. Such strength variations can be related to pre-existing crustal discontinuities, lateral changes in crustal thickness, thermal anomalies and possibly also to ancient subduction zones, presenting discontinuities within the continental mantle-lithosphere (Ziegler et al., 1998).

The intensity of collisional coupling between an orogen and its pro- and/or retro-wedge foreland is temporally and spatially variable (Hippolyte et al., 1994). Mechanisms controlling mechanical coupling of an orogen and its foreland(s) are still uncertain and require further research. However, the buoyancy of the subducting material (e.g. age of oceanic crust, Cloos, 1993) probably plays an important role, particularly in terms of the magnitude of slab-pull forces, controlling whether a passive margin is underplated (e.g. Himalayas) or its upper crustal parts are incorporated into the orogenic wedge (e.g. Alps). Moreover, the frictional shear strength and the geometry of the boundary layer between an orogenic wedge and its foreland presumably play an important role in the level of their mechanical coupling. In this respect, the build-up of high fluid pressures in subducted sediments, as well as the rheological contrast between them and the underlying basement, may account for mechanical decoupling of an orogenic wedge and its foreland(s) (Von Huene and Scholl, 1991, 1993; Degan and Robertson, 1994). Furthermore, the crustal configuration and rheological structure of a passive margin, as well as the presence or absence of a thick sedimentary cover, probably play a significant role in its subduction resistance, and consequently the magnitude of stresses that can be transmitted into it from a collision zone. Sheared and upper plate margins, characterized by a more abrupt continent-ocean transition zone, are likely to present greater subduction resistance than lower plate margins, characterized by a more gradual and drawn out thinning of the crust (Ziegler et al., 1998).

Strong mechanical coupling at crustal and mantlelithospheric levels between an orogenic wedge and its underthrusted foreland allows for the transmission of major tangential stresses into the latter, causing imbrication of the foreland crust and its incorporation into the orogenic wedge, as well as far-field inversion of extensional basins, upthrusting of basement blocks and lithospheric folding (e.g. Western and Central Alps, Atlas-Maghrebides, Ancestral Rocky Mtns., Arabian Taurus foreland, Midcontinent Arch, etc.). Whereas compressional stresses transmitted from the orogenic wedge into the foreland at lithospheric levels impede the development of purely flexural forebulges, their build-up can result in an amplitude accentuation of potentially preexisting forebulges (e.g. Appalachian Basin?) and in large radius lithospheric folding (e.g. Vosges-Black Forest Arch, North Sea Basin).

The tectono-stratigraphic record of forelands monitors the evolution of collision-related intraplate stress fields and thus the level of mechanical coupling between a foreland and the associated orogen. As such, it can contribute to dating of orogenic activity affecting the respective plate margin. 


\section{Conclusions}

Integration of geological and geophysical data and a review of the evolution of a wide spectrum of orogenic belts and their forelands in Europe, North Africa, Arabia and North America allows us to conclude that mechanical coupling between orogenic wedges and their cratonic forelands at supracrustal, crustal and mantle-lithospheric levels is temporally and spatially highly variable.

Mechanical coupling of an orogenic wedge and its foreland at supra-crustal levels is common and underlies the development of thin-skinned external fold-and-thrust belts (e.g. Appalachians, Rhenohercynian belt, Canadian Cordillera, Apennines). On the other hand, coupling at crustal levels is evidenced by the imbrication of the foreland crust, forming external crystalline massifs (e.g. Alps; Pyrenees), and by far-field inversion of tensional basins and upthrusting of basement blocks (e.g. Ancestral Rocky Mtns., Rocky Mtns, Alpine foreland, Atlas system, northern Urals). Furthermore, coupling at mantle lithospheric levels is indicated by far-field folding of the lithosphere, causing accelerated subsidence of intracratonic sedimentary basins (e.g. Michigan and North Sea basins) and/or the upwarping of broad arches (Transcontinental and Reguibat arches) and far-field reactivation of pre-existing crustal faults (e.g. Hudson Bay, Sahara Platform). Evidence for mechanical decoupling of an orogenic wedge at lithospheric levels during the emplacement of major allochthonous, partly basement-cored nappes comes from the Eastern Alps.

Following collision of an orogenic wedge with its continental foreland(s), and under conditions of their mechanical decoupling at lithospheric levels, retro-wedge foreland basins develop in response to tectonic and topographic loading of the underthrusted foreland lithosphere by the orogenic wedge. By contrast, the additional load of the subducted oceanic lithospheric slab contributes materially to the subsidence of pro-wedge foreland basins. Under such conditions, and in the presence of a foreland lithosphere characterized by a high $\mathrm{T}_{\mathrm{e}}$, a broad, low relief flexural forebulge may develop along the distal margin of the evolving foreland basin. However, in the presence of a rheologically weak foreland lithosphere, or one that is weakened by pre-existing crustal faults that can be reactivated during its load-induced deflection, loading stresses are not fully transmitted into the foreland; therefore, a flexural forebulge will not develop and the foreland basins will be narrow (e.g. East Carpathians). Moreover, if mechanical coupling of the orogenic wedge with the foreland is essentially restricted to supra-crustal levels, rheologically weak sedimentary layers, such as evaporites, shales and over-pressured sandstones, acting as stress guides, can be activated as detachment horizons. The thickness and composition of the supra-crustal sedimentary prism, and the distribution of potential detachment horizons within it, controls the structural style of the resulting thin-skinned fold-andthrust belt (see contrasting style of Mackenzie Mtns. and Alberta Foothills; Fig. 15). In the presence of a very thick sedimentary prism, thin-skinned thrusts can propagate far into the foreland, disrupting a pre-existing flexural basin (e.g. Mackenzie Mtns., Dinarides).

Under conditions of mechanical coupling of an orogenic wedge and its foreland(s) at crustal and/or mantlelithospheric levels, compressional stresses are transmitted from the collision zone into the foreland. Depending on the thickness, thermal regime and fluid content of the foreland crust, rheologically weak layers within it or at its base, acting as stress guides, can be activated as detachment horizons, controlling thick-skinned deformation of the foreland, including the upthrusting of external crystalline massifs, as well as far-field inversion of pre-existing tensional basins (e.g. Western Alps). Moreover, the base of the mechanical lithosphere can also be activated as a detachment horizon, allowing for lithospheric folding, involving narrowing and deepening of foreland basins and uplift of peripheral arches (e.g. Appalachian basin, southern Apennines), as well as far-field uplift of broad arches (e.g. Transcontinental Arch) and/or accelerated subsidence of sedimentary basins in the interior of a continent (e.g. Michigan and North Sea basins). Depending on the amplitude of such arches, decompressional partial melting of the lithospheric thermal boundary layer may occur (e.g. alkaline magmatism during uplift of the Sweetgrass Arch). Similarly, far-field large-scale intraplate compressional structure, such as inverted tensional basins and upthrusted basement blocks occurring at distances of up to $1700 \mathrm{~km}$ from a collision zone, probably reflect the transmission of collision-related compressional stresses at lithospheric levels (e.g. Ancestral Rocky Mtns., Northwest European inversion structures).

Collisional coupling between an Andean-type orogenic wedge and its retro-wedge foreland can occur during periods of accelerated convergence of the colliding oceanic lower plate and the continental upper plate and particularly during over-thickening of the orogen. The latter pertains specifically to retro-wedge domains which involved the closure of an oceanic back-arc basin (e.g. Cordilleran Havallah and Variscan Rhenohercynian basins); as crustal shortening progresses in such domains, gradually less attenuated foreland crust gets involved in the orogenic system and presents increasing subduction resistance. Moreover, when syn-orogenic crustal thickening, confined at lower crustal levels to a narrower zone than at upper crustal and supracrustal levels, attains a critical point, strain is preferentially partitioned to the external parts of the orogen and its foreland (e.g. Rocky Mtns.).

Pro-wedge forelands of evolving Himalayan-type orogenic wedges can be subjected to compressional stresses during

1) the initiation of a subduction zone (e.g. northwest Africa),

2) periods of subduction impediment caused by the arrival of more buoyant crust at a subduction zone (e.g. Central Alpine Helvetic Shelf), 
3) the initial collision of the orogenic wedge with a passive margin presenting considerable subduction resistance (e.g. East Alpine-North Carpathian foreland), and

4) post-collisional over-thickening and uplift of an orogenic wedge, involving the development of a mantleback-stop, and particularly during continued convergence after slab detachment (e.g. Central Alps).

Mechanical coupling and uncoupling of an orogenic wedge with its foreland(s) at lithospheric levels probably depends on convergence rates and directions (orthogonal or oblique), as well as on the frictional shear strength and the geometry of the boundary layer which separates the orogen and its foreland. In this respect, the crustal configuration and rheological structure of the colliding foreland margin, as well as whether or not a major subducted oceanic slab is attached to it, may have a bearing on in its subduction resistance. Moreover, the build-up of high fluid pressures in subducted sediments may play an important role in the degree of mechanical coupling between an orogenic wedge and its foreland at lithospheric levels. Obviously, more research needs to be directed towards understanding mechanisms which control the mechanical (de)coupling between orogenic wedges and their foreland(s).

Acknowledgement. The authors would like to thank all their colleagues, both in academia and industry, who contributed to this paper through many fruitful discussions and/or their publications. This pertains particularly to the case histories summarized in this paper on many of which one or an other of the authors has gained personal experience during his career. Although the authors have heavily drawn on the cumulative experience of their colleagues, they alone are responsible for the conclusions presented in this paper. Critical and constructive comments by F. Roure and H. Doust to an earlier version of this manuscript are gratefully acknowledged.

\section{References}

Åke Larson , S., Tullborg, E.-L., Cerderbom, C., and Stiberg, J.P.: Sveconorvergin and Caledonian foreland basins in the Baltic Shield revealed by fission-track thermochronlogy, Terra Nova, 11, 210-215, 1999.

Altherr, R. and Kalt, A.: Metamorphc evolution of ultrahighpressure garnet peridodites from the Variscan Vosges Mts. (France), Chemical Geol., 134, 27-47, 1996.

Andersen, A. and Hartz, E. H.: Basement-cover relationships and orogenic evolution in the Central Greenland Caledonides, GFF, 120, 191-198, 1998.

Anelli, L., Matavelli, L., and Pieri, M.: Structural-stratigraphic evolution of Italy and its petroleum systems, in: Ziegler, P. A. and Horvàth, F. (Eds.): Structure and Prospects of Alpine Basins and Forelands, Peri-Tethys Mem., 2. Mém, Mus. natn. Hist. nat., Paris, 170, 455-483, 1996.

Andeweg, B. and Cloetingh, S.: Flexure and 'unflexure' of the North Alpine German-Austrian Molasse Basin: constraints from forward tectonic modelling, in: Mascle, A., Puigdefàbregas, C., Luterbacher, H. P., and Fernandez, M. (Eds.): Cenozoic Foreland Basins of Western Europe, Geol. Soc., London, Spec. Publ., 134, 403-422, 1998.
Altherr, R., Henes-Klaiber, U., Hegner, E., Satir, M., and Langer, C.: Plutonism in the Variscan Odenwald (Germany): from subduction to collision, Int. J. Earth Sci., 88, 422-443, 1999.

Arbenz, J. K.: The Ouachita system, in: Bally, A. W. and Palmer, A. R. (Eds.): The Geology of North America; an overview, Geol. Soc. Am. The Geology of North America, vol. A, 371-396, 1989.

Argnani, A., Favali, P., Frugoni, F., Gasperini, M., Ligi, M., Marani, M., Mattietti, G., and Mele, G.: Foreland deformation pattern in the Southern Adriatic Sea, Ann. Geofisica, Bologna, XXXVI, 229-247, 1993.

Bachmann, G. H., Müller, M., and Weggen, K.: Evolution of the Molasse Basin (Germany, Switzerland), Tectonophysics, 137 77-92, 1987.

Bally, A. W., Gordy, P. L., and Stewart, G. A.: Structure, seismic data and orogenic evolution of southern Canadian Rocky Mountains, Bull. Can. Soc. Petrol. Geol., 20, 608-633, 1966.

Bally., A. W. (Ed.): Seismic Expression of Structural Styles, vol. 3, Tectonics of Compressional Provinces/Strike Slip Tectonics, Am. Assoc. Petrol. Geol., Studies in Geology, 15 (atlas), 1983.

Bally, A. W.: Phanerozoic basins of North America, in: Bally, A. W. and Palmer, A. R. (Eds.): The Gelogy of North America; an overview, Geol. Soc. Am. The Geology of North America, vol. A, 397-446, 1989.

Bally, A. W. and Snelson, S.: Realms of subsidence, in: Miall, A. D. (Ed.): Facts and Principles of World Petroleum Occurrence, Can. Soc. Petrol. Geol., Mem., 6, 9-94, 1980.

Baudrimont, A. F. and Dubois, P.: Un bassin mésogéen du domaine péri-alpin: Sud-Est de la France, Bull. Cent. Rech. Prod. ElfAquitaine, 1, 261-308, 1977.

Beaumont, C.: Foreland basins, Geophys. J. Roy. Astr. Soc., 65, 291-329, 1981.

Beaumont, C., Keen, C. E., and Boutillier, R.: A comparison of foreland and rift margin sedimentary basins, Phil. Trans. R. Soc., London, A 305, 295-317, 1982.

Beaumont, C., Quinlan, G. M., and Hamiltion, J.: The Alleghanian orogeny and its relationship to the evolution of the Eastern Interior, North America, in: Beaumont, C. and Tankard, T. (Eds.): Sedimentary Basins and Basin-Forming Mechanisms, Can. Soc. Petrol. Geol., Mem., 12, 425-445, 1987.

Beaumont, C., Fullsack, P., and Hamilton, J.: Styles of crustal deformation in compressional orogens caused by subduction of the underlying lithosphere, Tectonophysics, 232, 119-132, 1994.

Beck, C., Deville, E., Blanc, E., Philippe, Y., and Tardy, M.: Horizontal shortening control of middle Miocene marine siliciclastic accumulations (Upper Marine Molasse) in the southern termination of the Savaoy Molasse Basin (northwestern Alps/southern Jura), in: Mascle, A., Puigdefàbregas, C., Luterbacher, H. P., and Fernandez, M. (Eds.): Cenozoic Foreland Basins of Western Europe, Geol. Soc., London, Spec. Publ., 134, 263-278, 1998.

Bertotti, G., Picotti, V., and Cloetingh, S.: Lithospheric weakening during "retroforeland" basin formation: Tectonic evolution of the central South Alpine foredeep, Tectonics, 17, 131-142, 1998.

Bertotti, G., Casolari, E., and Picotti, V.: The Gargano Promontory: a Neogene contractional belt within the Adriatic plate, Terra Nova, 11, 168-173, 1999.

Bessereau, G., Roure, F., Kontarba, A., Kusmierek, J., and Strzetelski, W.: Structure and hydrocarbon habitat of the Polish Carpathians, in: Ziegler, P. A. and Horvàth, F. (Eds.): Structure and Prospects of Alpine Basins and Forelands, Peri-Tethys Mem. 2. Mém. Mus. natn. Hist. nat., Paris, 170, 343-373, 1996. 
Bijwaard, H., Spakman, W., and Engdahl, E. R.: Closing the gap between regional and global travel time tomography, J. Geophys. Res., 103, 30 055-30 078, 1998.

Bird, K. J. and Molenaar, C. M.: The North Slope foreland basin, Alaska, in: Macqueen, R. W. and Leckie, D. A. (Eds.): Foreland Basins and Fold Belts, Am. Assoc. Petrol. Geol. Mem., 55, 363293, 1992.

Bodine, J. H., Steckler, M. S., and Watts, A. B.: Observations on flexure and the rheology of the oceanic lithosphere, J. Geophys. Res., 86, 3695-3707, 1981.

Boote, D. R. D., Clark-Lowes, D. D., and Traut, M. W.: Palaeozoic petroleum systems of North Africa, in: Macgregor, D. S., Moody, R. T. J., and Clark-Lowes, D. D. (Eds.): Petroleum Geology of North Africa, Geol. Soc., London, Spec. Publ., 132, 7-68, 1998.

Bousquet, R., Goffé, B., Henry, P., Le Pichon, X., and Chopin, C.: Kinematic, thermal and petrological model of the Central Alps: Lepontoine metamorphism in the upper crust and eclogitisation of the lower crust, Tectonophysics, 273, 105-127, 1997.

Bott, M. H. P.: The Interior of the Earth: Its Structure, Constitution and Evolution, Edward Arnold, London, 403 p. (2nd Ed.), 1982.

Bott, M. H. P.: Stress distribution and plate boundary forces associated with collision mountain ranges, Tectonophysics, 182, 193-209, 1990.

Bott, M. H. P.: Modelling of plate-driving mechanisms, J. Geol. Soc., London, 150, 941-951, 1993.

Bracène, R., Bellahcène, A., Bekkouke, D., Mercier, E., and Frizon de Lamotte, D.: The thin-skinned style of the South Atlas front in central Algeria, in: Macgregor, D. S., Moody, R. T. J., and Clark-Lowes, D. D. (Eds.): Petroleum Geology of North Africa, Geol. Soc., London, Spec. Publ., 132, 392-404, 1998.

Brzobohaty, J., Benada, S., Berka, J., and Rehanek, J.: Hydrocarbon habitat of the Paleogene Nesvacilka Trough, Carpathian foreland basin, Czech Republic, in: Ziegler, P. A. and Horvàth, F. (Eds.): Structure and Prospects of Alpine Basins and Forelands, PeriTethys Mem., 2. Mém. Mus. natn. Hist. nat., Paris, 170, 305-319, 1996.

Büchi, U. P. and Schlanke, S., Zur Paläogeographie der schweizerischen Molasse. Erdöl-Erdgas Z., Spec. Issue, 993, 57-69, 1977.

Burkhard, M. and Sommaruga, A.; Evolution of the western Swiss Molasse basin: structural relations with the Alps and the Jura belt, in: Mascle, A., Puigdefàbregas, C., Luterbacher, H. P., and Fernandez, M. (Eds.): Cenozoic Foreland Basins of Western Europe, Geol. Soc., London, Spec. Publ., 134, 279-298, 1998.

Burov, E. B. and Diamet, M.: The effective elastic thickness (Te) of continental lithosphere: What does it really mean? Geophys. Res., 100, 3905-927, 1995.

Casnedi, R.: Subsurface basin analysis of fault-controlled turbidite system in Bradano Trough, Southern Adriatic foredeep, Italy, Am. Assoc. Petrol. Geol. Bull., 72, 1370-1380, 1988.

Cassano, E., Anelli, L., Fichera, R., and Cappelli, V.: Pianura Padana, interpretazione integrata di dati geofisici et geologici, AGIP, 73th Congr. Soc. Geol. It., Roma, 27 p, 1986.

Cederbom, C., Åke Larson, S., Tullborg, E.-L., and Stiberg, J.-P.: Fission track thermochronology applied to Phanerozoic thermotectonic events in central and southern Sweden, Tectonophysics, 316, 153-163, 2000.

Chalot-Prat, F. and Girbacea, R.: Partial delamination of continental mantle- lithosphere, ulift-related crust-mantle decoupling, volcanism and basin formation: a new model for the PlioceneQuaternary evolution of the southern East-Carpathians, Roma- nia, Tectonophysics, 327, 83-107, 2000.

Cloetingh, S.: Intraplate stresses: a new element in basin analysis, in: Kleinspehn, K. L. and Parks, C. (Eds.): New Perspectives in Basin Analysis, Springer-Verlag, New York, 205-230, 1988.

Cloetingh, S. and Burov, E.: Thermomechanical structure of European continental lithosphere: constraints from rheological profiles and EET estimates, Geophys. J. Int., 124, 695-723, 1995.

Cloetingh, S. and Wortel, R.: Stresses in the Indo-Australian plate, Tectonophysics, 132, 49-67, 1986.

Cloetingh, S., Burov, E., and Poliakov, A.: Lithosphere folding: primary response to compression? (from central Asia to Paris basin), Tectonics, 18, 1064-1083, 1999.

Cloetingh, S., Kooi, H., and Groenewoud, W.: Intraplate stress and sedimentary basin evolution, in: Price, R. A. (Ed.): Origin and Evolution of Sedimentary Basins and their Energy and Mineral Resources, Am. Geophys. Un., Geophys. Monogr., 48, 1-16, 1989.

Cloos, M.: Lithospheric buoyancy and collisional orogenies: subduction of oceanic plateaux, continental margins, island arcs, spreading ridges and seamounts, Geol. Soc. Am. Bull., 105, 715735, 1993.

Cobbold, P. R., Davy, P., Gapais, D., Rossello, E. A., Sadybakasov, E., Thomas, J. C., Tondji Biyo, J. J., and De Urreiztieta, M.: Sedimentary basins and crustal thickening, Sedim. Geol., 86, 7789, 1993.

Cook, J. D. and Bally, A. W.: Stratigraphic Atlas North and Central America, Princeton, New Jersey, Princeton University Press, 272 p, 1975.

Craddock, J. P., Jackson, M., and Van der Pluijm, P. A.: Regional shortening fabric in eastern North America from the Appalachian-Ouachita orogenic belt, Tectonics, 12, 257-264, 1993.

Crampton, S. L. and Allan, P. A.: Recognition of forebulge unconformities associated with early stage foreland basin development: example from the North Alpine Foreland Basin, Am. Assoc. Petrol. Geol. Bull., 79, 1495-1514, 1995.

De Boorder, H., Spakman, W., White, S. H., and Wortel, M. J. R.: Late Cenozoic mineralization, orogenic collapse and slab detachment in the European Alpine Belt, Earth Planet. Sci. Lett., 164, 569-575, 1998.

Degan, P. and Robertson, A.: Early Tertiary melange in the Peleponese (Southern Greece) formed by subduction-accretion processes, Bull. Geol. Soc. Greece XXX/2, 93-107, 1994.

Dicea, O.: Structure and hydrocarbon geology of the Romanian East Carpathian border from seismic data, Petrol. Geosci., 1, 135-143, 1995.

Dicea, O.: Tectonic setting and hydrocarbon habitat of the Romanian external Carpathians, in: Ziegler, P. A. and Horvàth, F. (Eds.): Structure and Prospects of Alpine Basins and Forelands, Peri-Tethys Mem., 2. Mém. Mus. natn. Hist. nat., Paris, 170, 403-425, 1996.

Diraison, M., Cobbold, P. R., Gapais, D., Rossello, E. A., and Le Corre, C.: Cenozoic crustal thickening, wrenching and rifting in the foothills of the southernmost Andes, Tectonophysics, 316, 91-119, 2000.

Doglioni, C: Some remarks on the origin of foredeeps. Tectonophysics, 228, 1-20, 1993.

Doglioni, C., Mongelli, F., and Prieri, P.: The Puglia uplift (SE Italy): an anomaly in the foreland of the Apennine subduction due to buckling of a thick continental lithosphere, Tectonics, 13, 1309-1321, 1994.

Doglioni, C., Gueguen, E., Harabaglia, P., and Mongelli, F.: On 
the origin of west-directed subduction zones and application to the western Mediterranean, in: Durand, B., Jolivet, L., Horvàth, F., and Séranne, F. (Eds.): The Mediterranean Basin: Tertiary Extension within the Alpine Orogen, Geol. Soc., London, Spec. Publ., 156, 541-561, 1999.

Dykstra, J. C. F. and Longman, M. W.: Gas reservoir potential of the Lower Ordovician Beekmanstown Group, Quebec Lowlands, Canada, Am. Assoc. Petrol. Geol. Bull., 79, 513-530, 1995.

Egan, S. S. and Urquhart, J. M.: Numerical modelling of lithosphere shortening: application to the Laramide orogenic province, western U.S.A., Tectonophysics, 221, 385-411, 1993.

Ellouz, N. and Roca, E.: Palinspastic reconstruction of the Carpathian and adjacent areas since the Cretaceous: a quantitative approach, in: Roure, F. (Ed.): Peri-Tethyan Platforms, Ed. Technip, Paris, pp. 51-78, 1994.

Engeser, T. and Schwentke, W.: Towards a new concept of the tectogenesis of the Pyrenees, Tectonophysics, 129, 233-242, 1986.

Fleitout, L. and Froidevaux, C.: Tectonics and topography for lithosphere containing density heterogeneities, Tectonics, 1, 21-56, 1982.

Fokin, P., Nikishin A. M., and Ziegler, P. A.: Peri-Uralian and PeriPalaeo- Tethyan rift systems and the East European Craton, in: Ziegler, P. A., Cavazza, W., Robertson, A. H. F., and CrasquinSoleau, S. (Eds.): PeriTethyan Rift/Wrench Basins and Passive Margins, Peri-Tethys Mem., 6. Mém. Mus. natn. Hist. nat., Paris, 186, 347-368, 2001

Ford, M.: Kinematics and geometry of early Alpine basementinvolved folds, SW Pelvoux Massif, SE France, Eclog. Geol. Helv., 89, 269-295, 1996.

Frasheri, A., Nishani, P., Bushati, S., and Hyseni, A.: Relationship between tectonic zones of the Albanides based on results of geophysical studies, in: Ziegler, P. A. and Horvàth, F. (Eds.): Structure and Prospects of Alpine Basins and Forelands, Peri-Tethys Mem. 2. Mém. Mus. natn. Hist. nat., Paris, 170, 485-511, 1996.

Frazier, W. J. and Schwimmer, D. R.: Regional Stratigraphy of North America, Plenum Press, New York and London, 719 p, 1987.

Frizon de Lamotte, D., Mercier, E., Saint Bezar, B., and Bracène, R.: Two Step Atlas Building and Geodynamics of the West Mediterranean, Tectonics 19, 740-761, 2000.

Gaspar-Escribano, J. M., Van Wees, J. D., Ter Voorde, M., Cloetingh, S., Roca, E., Cabrera, L., Muñoz, J. A., Ziegler, P. A., and Garcia-Castellano, D.: Three-dimensional flexural modelling of the Ebro Basin (NE Iberia), Geophys. J. Int., 145, 349-367, 2001.

Gao, D., Shumaker, R. C., and Wilson, T. H.: Along-axis segmentation and growth history of the Rome Trough in the Central Appalachian Basin, Am. Assoc. Petrol. Geol. Bull., 84, 75-99, 2000.

Gee, D. G.: Nappe displacement in the Scandinavian Caledonides, Norsk geol. Tidsskr., 61, 93-95, 1978.

Gee, D. G., Guezou, J.-C., Roberts, D., and Wolff, F.-C.: The central-southern par of the Scandinavian Caledonides, in: Gee, D. G. and Sturt, B. A.: (Eds.): The Caledonian Orogen - Scadinavia and Related Areas, John Wiley and Sons, 109-133, 1985.

Georgiev, G., Dabovski, C., and Stanisheva-Vassileva, G.: East Srednegories- Balkan rift Zone, in: Ziegler, P. A., Cavazza, W., Robertson, A. H. F., and Crasquin-Soleau, S. (Eds.): PeriTethyan Rift/Wrench Basins and Passive Margins, Peri-Tethys Mem., 6. Mém. Mus. natn. Hist. nat., Paris, 186, 259-293, 2001.

Gilmour, N. and Mäkel, G.: 3D geometry and kinematics of the N. V. Turkse Shell thrustbelt oil fields, Southeast Turkey, in:
Ziegler, P. A. and Horvàth, F. (Eds.): Structure and Prospects of Alpine Basins and Forelands, Peri-Tethys Mem., 2. Mém. Mus. natn. Hist. nat., Paris, 170, 524-547, 1996.

Grand, S. P., Van der Hilst, R. D., and Widiyantoro, S.: Global seismic tomography: a snapshot of convection in the Earth, GSA Today, 7, 17, 1997.

Greiling, R. O., Garfunkel, Z., and Zachrisson, E.: The orogenic wedge in the central Scandinavian Caledonides: Scandian structural evolution and possible influence on foreland basin, GFF, 120, 181-190, 1998.

Gries, R., Dolson, J. C., and Raynolds, R. G. H.: Structural and stratigraphic evolution and hydrocarbon distribution, Rocky Mountain foreland, in: Macqueen, R. W. and Leckie, D. A. (Eds.): Foreland Basins and Fold Belts, Am. Assoc. Petrol. Geol. Mem., 55, 395-425, 1992.

Gueguen, W., Doglioni, C., and Fernandez, M.: On the post-25 Ma geodynamic evolution of the western Mediterranean, Tectonophysics, 298, 259-269, 1998.

Gunzenhauser, B., Meier, B., and Zimmer, W.: Compressional tectonics and hydrocarbon aspects of the Ternberg-Ost area (Upper Austria), Am. Assoc. Petrol. Geol. Bull., 81, 1379 (abstract), 1997.

Hauber, L., Über das Tertiär im nordschweizerischen Tafeljura, Eclog. Geol. Helv., 53, 656-668, 1961.

Herb, R., Eozäne Paläographie und Paläotektonik des Helvetikums, Eclog. Geol. Helv., 81, 611-657, 1988.

Hippolyte, J.-C., Angelier, J., Roure, F., and Casero, P.: Piggyback basin development and thrust belt evolution: structural and palaeostress analysis of Plio-Quaternary basins in the southern Apennines, J. Struct. Geol., 6, 159-171, 1994.

Howell, P. D. and Van der Pluijm, B. A.: Structural sequences and styles of subsidence in the Michigan basin, Geol. Soc. Am. Bull., 111, 974-991, 1999.

Izotova, T. S. and Popadyuk, I. V.: Oil and gas accumulations in the Late Jurassic reefal complex of the West Ukrainian Carpathian foredeep, in: Ziegler, P. A. and Horvàth, F. (Eds.): Structure and Prospects of Alpine Basins and Forelands, Peri-Tethys Mem., 2. Mém. Mus. natn. Hist. nat., Paris, 170, 375-390, 1996.

Jervey, M. T.: Siliciclastic sequence development in foreland basins, with examples from the Western Canada foreland basin, in: Macqueen, R. W. and Leckie, D. A. (Eds.): Foreland Basins and Fold Belts, Am. Assoc. Petrol. Geol. Mem., 55, 47-80, 1992.

Johansen, S. E., Ostisty, B. K., Birkeland, Ø., Federovsky, Y. F., Martirosjan, V. N., Bruun Christensen, O., Cheredeev, S. I., Ignatenko, E. A., and Margulis, L. S.: Hydrocarbon potential in the Barents Sea region: play distribution and potential, in: Vorren, T. O., Bergsager, E., Dahl-Stamnes, Ø. A., Holter, E., Johansen, B., Lie, E., and Lund, T. B. (Eds.): Arctic Geology and Petroleum Potential, Norwegian Petrol. Soc., Spec. Publ., 2, 273-320, 1992.

Johnson, D. D. and Beaumont, C.: Preliminary results from a planform kinematic model of orogen evolution, surface processes and the development of clastic foreland basin stratigraphy, Spec. Publ. Soc. Econ. Paleont. Mineral., 52, 3-24, 1995.

Jordan, T. E.: Thrust loads and foreland basin evolution, Cretaceous, western United States, Am. Assoc. Petrol. Geol. Bull., 65, 2506-2520, 1981.

Karner, G. D. and Watts, A. B.: Gravity anomalies and flexure of the lithosphere at mountain ranges, J. Geophys. Res., 88, 10449 $10477,1983$.

Kerr, J. W.: Cornwallis fold belt and mechanisms of basement uplift, Can. J. Earth Sci., 1402-1426, 1977. 
Kerr, J. W.: Evolution of the Canadian Arctic Islands: a transition between the Atlantic and Arctic Ocean, in: Nairn, A. E. M., Churkin jr., M., and Stehli, F. G. (Eds.): The Ocean Basins and Margins, vol. 5, The Arctic Ocean, Plenum Press, New York, 105-199, 1981.

Kluth, C. F.: Plate tectonics of the Ancestral Rocky Mountains, in: Peterson, J. E. (Ed.): Paleotectonics and Sedimentation in the Rocky Mountain Region, United States, Am. Assoc. Petrol. Geol. Mem., 41, 353-369, 1986.

Kollmann, K. and Malzer, O.: Die Molassezone Oberösterreichs und Salzburgs, in: Brix, F. and Schultz, O. (Eds.): Erdöl und Erdgas in Österreich, Naturhistorisches Museum Wien, 179-201, 1980.

Kovac, M., Nagymarosi, A., Sotak, J, and Sutovska, K.: Late Tertiary palaeogeography of the West Carpathians, Tectonophysics, 226, 401-415, 1993.

Lallemand, S., Culotta, R., and Von Huene, R.: Subduction of the Daiichi Kashima seamount in the Japan Trench, Tectonophysics, 160, 231-247, 1989.

Lallemand, S. E., Malavieille, J., and Calassou, S.: Effects of ocean ridge subduction on accretionary wedges: experimental modelling and marine observations, Tectonics, 11, 1301-1313, 1992.

Lallemant, S., Chamot-Rooke, N., Le Pichon, X., and Rangin, C.: Zenisu Ridge: a deep intraoceanic thrust related to subduction, off Southwest Japan, Tectonophysics, 160, 151-174, 1989.

Lammerer, B. and Weger, M.: Footwall uplift in an orogenic wegde: the Tauern Window in the Eastern Alps of Europe, Tectonophysics, 285, 213-230, 1998.

Laubscher, H. P.: Die tektonische Entwicklung des Nordschweiz, Eclog. Geol Helv., 30, 287-303, 1987.

Laubscher, H. P.: Jura kinematics and the Molasse Basin, Eclog. Geol. Helv., 85, 653-675, 1992.

Lefort, J. P. and Agarwal, B. N. P.: Gravity evidence for an Alpine buckling of the crust beneath the Paris Basin, Tectonophysics, 258, 1-14, 1996.

Leckie, D. A. and Smith, D. G.: Regional setting, evolution, and depositional cycles of the Western Canada foreland basins, in: Macqueen, R. W. and Leckie, D. A. (Eds.): Foreland basins and fold belts, Am. Assoc. Petrol. Geol. Mem., 55, 9-46, 1992.

Lemoine, M. and De Graciansky, P. C.: Histoire d'une marge continentale passive: les Ales occidentales au Mésozoique, Introduction, Bull. Soc. géol. France, 8(IV), 597-600, 1988

Le Pichon, X., Henry, P., and Goffé, B.: Uplift of Tibet: from eclogite to granulite - implications for the Andean Plataeu and the Variscan belt, Tectonophysics, 273, 57-76, 1997.

Le Vot, M., Biteau, J. J., and Masset, J. M.: The Aquitaine Basin: oil and gas production in the foreland of the Pyrenean fold-andthrust belt. New exploration perspectives, in: Ziegler, P. A. and Horvàth, F. (Eds.): Structure and Prospects of Alpine Basins and Forelands, Peri-Tethys Mem., 2. Mém. Mus. natn. Hist. nat., Paris, 170, 159-171, 1996.

Lickorish, W. H. and Ford, M.: Sequential restoration of the external Alpine Digne thrust system, SE France, constrained by kinematic data and synorogenic sediments, in: Mascle, A., Puigdefàbregas, C., Luterbacher, H. P. and Fernandez, M. (Eds.): Cenozoic Foreland Basins of Western Europe, Geol. Soc., London, Spec. Publ., 134, 189-211, 1998.

Lucente, F. P. and Speranza, F.: Belt bending driven by lateral bending of subducted lithospheric slab: geophysical evidence from the northern Apennines (Italy), Tectonophysics, 337, 5364, 2001.

Masson, D. G., Cartwright, J. A., Pinheiro, L. M., Whitmarsh, R. B.,
Beslier, M.-O., and Roeser, H.: Compressional deformation at the continent-ocean transition in the NE Atlantic, J. Geol. Soc., London, 151, 607-613, 1994.

Matenco, L. and Bertotti, G.: Tertiary tectonic evolution of the external East Carpathians (Romania), Tectonophysics, 316, 255286, 2000.

Matte, P., Continental subduction and exhumation of HP rocks in Paleozoic orogenic belts: Uralides and Variscides, GFF, 120, 209-222, 1998.

Mayoraz, R.: Les brèches tertiaires du flanc inverse de la nappe de Morcles et des unités parautochtones (Bas Valais, Suisse), Eclog. Geol. Helv., 88, 312-345, 1995.

McBriden, J. H. and Nelson, W. J.: Style and origin of midCarboniferous deformation in the Illinois Basin, USA - Ancestral Rockies deformation? Tectonophysics, 305, 249-273, 1999.

McNutt, M. K., Diamet, M., and Kogan, M. G.: Variations of elastic plate thickness at continental thrust belts, J. Geophys. Res., 93, 8825-8835, 1988.

Meckel jr., L. D., Smith, D. G., and Wells, L. A.: Ouachita foredeep basins: regional paleogeography and habitat of hydrocarbons, in: Macqueen, R. W. and Leckie, D. A. (Eds.): Foreland Basins and Fold Belts, Am. Assoc. Petrol. Geol. Mem., 55, 427-444, 1992.

Menkveld-Gfeller, O.: Stratigraphie, Fazies und Paläogeographie des Eozäns der helvetischen Decken der Westschweiz (Diablerets- und Wildhorn-Decke), Eclog. Geol. Helv., 88, 115-134, 1995.

Milanovsky, E. E.: Geology of the USSR, Part 1, Moscow University Press, Moscow, 416 p (in Russian), 1987.

Millan, H., Den Bezemer, B. T., Verges, J., Marzo, M., Munoz, J. A., Roca, E., Cires, J., Zoetemeijer, R., Cloetingh, S., and Puigdefábregas, C.: Paleo-elevation and EET evolution of mountain ranges: Inferences from flexural modelling in the Eastern Pyrenees and Ebro Basin, Mar. Petrol. Geol., 12, 917-928, 1995.

Mostardini, F. and Merlini, S.: Appenninico centro meridionale, sezioni geologiche e proposta di modello strutturale, AGIP, 73th Cong. Soc. It., Roma, 36 p, 1986.

Mueller, S. and Phillips, R. J.: On the initiation of subduction, J. Geophys. Res., 96, 651-666, 1991.

Müller, B., Wehrle, V., Zeyen, H., and Fuchs, K.: Short-scale variations of tectonic regimes in the western European stress province north of the Alps and Pyrenees, Tectonophysics, 275, 199-219, 1997.

Nachtmann, W. and Wagner, J.: Mesozoic and early Tertiary evolution of the Alpine foreland in Upper Austria and Salzburg, Austria, Tectonophysics, 137, 61-76, 1987.

Noguera, A. M. and Rea, G.: Deep structure of the CampanianLucanian arc (Southern Apennine, Italy), Tectonophysics, 324, 239-265, 2000.

Nikishin, A. M., Ziegler, P. A., Stephenson, R. A., Cloetingh, S. A. P. L., Furne, A. V., Fokin, P. A., Ershov, A. V., Boloytov, S. N., Korotaev, M. V., Alekseev, A. S., Gorbachev, V. I., Shipilov, E. V., Lankreijer, A., Bembinova, E. Yu., and Shalimov, I. V.: Late Precambrian to Triassic history of the East European Craton: dynamics of sedimentary basin evolution, Tectonophysics, 268, 23-63, 1996.

Nikishin, A. M., Ziegler, P. A., Panov, D. I., Nazarevich, B. P., Brunet, M.-F., Stephenson, R. A., Bolotov, S. N., Korotaev, M. V., and Tikhomirov, P.: Mesozoic and Cenozoic evolution of the Scythian platform-Back Sea-Caucasus domain, in: Ziegler, P. A., Cavazza, W., Robertson, A. H. F., and Crasquin-Soleau, S. (Eds.): PeriTethyan Rift/Wrench Basins and Passive Margins, Peri-Tethys Mem., 6. Mém. Mus. natn. Hist. nat., Paris, 186, 
295-346, 2001.

Oldow, J. S., Bally, A. W., Avé Lallemant, H. G., and Leeman, W. P.: Phanerozoic evolution of the North American Cordillera; United States and Canada, in: Bally, A. W. and Palmer, A. R. (Eds.): The Gelogy of North America; an overview, Geol. Soc. Am. The Geology of North America, vol. A, 139-232, 1989.

Oncken, O., Von Winterfeld, C., and Dittmar, U.: Accretion of a rifted passive margin - the Late Paleozoic Rhenohercynian fold and thrust belt (Mid-European Variscides), Tectonics, 18, 75-91, 1999.

Pamic, J., Gusic, I., and Jelaska, V.: Geodynamic evolution of the Central Dinarides, Tectonophysics, 297, 251-268, 1998.

Peper, T., Bekman, F., and Cloetingh, S.: Consequences of thrusting and intraplate stress fluctuation for vertical motions of foreland basins and peripheral areas, Geophys. J. Int., 111, 104-126, 1992.

Peper, T., Van Balen, R. T., and Cloetingh, S.: Implications of orogenic wedge growth, intraplate stress variations and eustatic sealevel changes for foreland basin stratigraphy: inferences from numerical modeling, in: Dorobek, S. and Ross, G. (Eds.): Stratigraphic development in foreland basins, Soc. Econ. Paleont. Mineral., Spec. Publ., 52, 25-35, 1994.

Perez-Estaún, A., Alvarez-Merrón, J., Brown, D., Puchkov, V., Gorozhanina, Y., and Baryshev, V.: Along-strike variations in the foreland thrust and fold belt of the southern Urals, Tectonophysics, 276, 265-280, 1997.

Pharaoh, T. C.: Palaeozoic terranes and their lithospheric boundaries with the Trans-European Suture Zone (TESZ), Tectonophysics, 314, 17-41, 1999.

Philippe, Y., Colletta, B., Deville, E., and Mascle, A.: The Jura foldand-thrust belt: a kinematic model based on map-balancing, in: Ziegler, P. A. and Horvàth, F. (Eds.). Structure and Prospects of Alpine Basins and Forelands, Peri-Tethys Mem., 2. Mém. Mus. natn. Hist. nat., Paris, 170, 235-261, 1996.

Philippe, Y., Deville, E., and Mascle, A.: Thin-skinned inversion tectonics at oblique basin margins: example of the western Vercors and Chartreuse Subalpine massifs (SE France), in: Mascle, A., Puigdefàbregas, C., Luterbacher, H. P., and Fernandez, M. (Eds.): Cenozoic Foreland Basins of Western Europe, Geol. Soc., London, Spec. Publ., 134, 239-262, 1998.

Poprawa, P., Sliaupa, S., Stephenson, R., and Lazauskiené J.: Late Vendian-Early Palaeozoic tectonic evolution of the Baltic Basin: regional tectonic implications from subsidence analysis, Tectonophysics, 314, 219-239, 1999.

Price, R. A.: Large-scale gravitational flow of supracrustal rocks, southern Canadian Rockies, in: De Jong, K. A. and Scholten, R. (Eds.): Gravity and Tectonics, John Wiley, New York, 491-502, 1973.

Prodehl, C., Müller, St., and Haak, V.: The European Cenozoic rift system, in: Olsen, K. H. (Ed.): Continental Rifts: Evolution, Structure, Tectonics. Development in Geotectonics, Elsevier, Amsterdam, 25, 133-212, 1995.

Puchkov, V. N.: Structure and geodynamics of the Uralian orogen, in: Burg, J.-P. and Ford, M. (Eds.): Orogeny through time, Geol. Soc., London, Spec. Publ., 121, 201-236, 1997.

Quinlan, G. M. and Beaumont, C.: Appalachian thrusting, lithospheric flexure, and the Paleozoic stratigraphy of the eastern interior of North America, Can. J. Earth Sci., 21, 973-996, 1984.

Rast, N.: The evolution of the Appalachia chain, in: Bally, A. W., and Palmer, A. R. (Eds.): The Gelogy of North America; an overview, Geol. Soc. Am. The Geology of North America, vol. A, 323-348, 1998.
Razin, P., Bonijoly, D., La Strat, P., Courel, L., Poli, E., Dormart, G., and Elmi, S.: Stratigraphic record of structural evolution of the western extensional margin of the Subalpine Basin during the Triassic and Jurassic, Ardèche, France, Mar. Petrol. Geol., 13, 625-652, 1996.

Robertson, A. and Shallo, M.: Mesozoic-Tertiary tectonic evolution of Albania in its regional Eastern Mediterranean context, Tectonophysics, 316, 197-254, 2000.

Robinson, P., Tucker, R. D., Bradley, D., Berry, H. N., and Osberg, P. H.: Paleozoic orogens in New England, USA, GFF, 120, 119 148, 1998.

Roca, E.: The Northwest Mediterranean Basin (Valencia Trough, Gulf of Lions and Liguro-Provençal basins): structure and geodynamic evolution, in: Ziegler, P. A., Cavazza, W., Robertson, A. H. F., and Crasquin-Soleau, S. (Eds.): PeriTethyan Rift/Wrench Basins and Passive Margins, Peri-Tethys Mem., 6. Mém. Mus. natn. Hist. nat., Paris, 186, 671-706, 2001.

Roden-Tice, M. K., Tice, S. J., Schofield, I. S., and Michaud, D. P.: Evidence for differential unroofing in the Adirondack Mountains, New York State through Apatite fission-track thermochronology, GSA Abstracts with Programs, Abstr. BTH, 44, 1998.

Roeder, D. and Bachmann, G.: Evolution, structure and petroleum geology of the German Molasse Basin, in: Ziegler, P. A. and Horvàth, F. (Eds.): Structure and Prospects of Alpine Basins and Forelands, Peri-Tethys Mem., 2. Mém. Mus. natn. Hist. nat., Paris, 170, 263-284, 1996.

Roeder, D. and Lindsey, D.: Barcis area (Vento, Friuli, Slovenian): architecture and geodynamics, NAFTA, 43, 509-548, 1992.

Root, S. and Onasch, C. M.: Structure and tectonic evolution of the transitional region between the central Appalachian foreland and the interior cratonic basins, Tectonophysics, 305, 205-223, 1999.

Ross, C. A. and Ross, J. R. P.: Paleozoic paleotectonics and sedimentation in Arizona and New Mexico, in: Peterson, J. E. (Ed.): Paleotectonics and Sedimentation in the Rocky Mountain Region, United States, Am. Assoc. Petrol. Geol., Mem., 41, 653668, 1986.

Roure, F. and Colletta, B.: Cenozoic inversion structures in the foreland of the Pyrenees and Alps, in: Ziegler, P. A. and Horvàth, F. (Eds.): Structure and Prospects of Alpine Basins and Forelands, Peri-Tethys Mem., 2. Mém. Mus. natn. Hist. nat., Paris, 170, 73 209, 1996.

Roure, F., Choukroune, P., and Polino, R.: Deep seismic reflection data and new insights on the bulk geometry of mountain ranges, Comptes Rend. Acad. Sci. Paris, 322 (IIa), 345-359, 1996.

Royden, L.: Flexural behaviour of the continental lithosphere in Italy: constraints imposed by gravity and deflection data, J. Geophys. Res., 91, 7747-7766, 1988.

Royden, L. H.: The tectonic expression of slab pull at continental convergent boundaries, Tectonics, 93, 303-325, 1993.

Salel, J. F. and Séguret, M.: Late Cretaceous to Paleogene thinskinned tectonics of the Palmyrides belt (Syria), Tectonophysics, 273, 1-16, 1994.

Sanders, C. A., Andriessen, P. A. M., and Cloetingh, S.: Tectonic and erosion, competitive forces in a compressive orogen: a fission track study of the Romanian Carpathians, J. Geophys. Res., 104, 29095-29 112, 1999.

Sawaf, T., Brew, G., Litak, R., and Barazangi, M.: Geologic evoolution of the intraplate Palmyride Basin and Euphrates fault system, Syria, in: Ziegler, P. A., Cavazza, W., Robertson, A. H. F., and Crasquin-Soleau, S. (Eds.): PeriTethyan Rift/Wrench Basins 
and Passive Margins, Peri-Tethys Mem., 6. Mém. Mus. natn. Hist. nat., Paris, 186, 441-467, 2001.

Schmid, S. M., Pfiffner, O. A., Froitzheim, N., Schönborn, G., and Kissling, E.: Geological-geophysical transect and tectonic evolution of the Swiss-Italian Alps, Tectonics, 15, 1036-1064, 1996.

Schmid, S. M. and Kissling, E.: The arc of the western Alps in the light of geophysical data on deep crustal structure, Tectonics, 19, 62-85, 2000.

Schofield, I. S., Rabideau, P., Hewson, E., Roden-Tice, M., and Tice, S.: Thermal history of the Adirondack Mountains, New York, based on Apatite fission-track thermochronology, GSA Abstracts with Programs, Northeastern Section, Abstr. No. $15041,1997$.

Seghedi, A.: The North Dobrogea orogenic belt (Romania): a review, in: Ziegler, P. A., Cavazza, W., Robertson, A. H. F., and Crasquin-Soleau, S. (Eds.): PeriTethyan Rift/Wrench Basins and Passive Margins, Peri-Tethys Mem., 6. Mém. Mus. natn. Hist. nat., Paris, 186, 237-257, 2001.

Sella, M., Turci, C., and Riva, A.: Petroleum geology of the "Fossa Bradanica" (foredeep of the Southern Apennine trust belt), in: Brooks, J. (Ed.): Classical petroleum provinces, Geol. Soc., London, Spec. Publ., 50, 369-378, 1990.

Séguret, M. and Dagnères, M., Coupes balancèes d'échelle crustale des Pyrenées, C.R. Acad. Sci. Paris, 301, Ser. II(5), 341-346, 1985.

Séranne, M.: The Gulf of Lion continental margin (NW Mediterranean) revisited by IBS: an overview, in: Durand, B., Jolivet, L., Horvàth, F., and Séranne, F. (Eds.): The Mediterranean Basin: Tertiary Extension within the Alpine Orogen, Geol. Soc., London, Spec. Publ., 156, 15-36, 1999.

Sissingh, W.: Comparative Tertiary stratigraphy of the Rhine Graben, Bresse Graben and Molasse Basin: correlation of Alpine foreland events, Tectonophysics, 300, 249-284, 1998.

Sissingh, W.: Tectonostratigraphy of the West Alpine Foreland: correlation of Tertiary sedimentary sequences, changes in global sea-level and syn-orogenic stress regimes, Tectonophysics, 333, 361-400, 2001.

Slaczka, A.: Oil and gas in the Northern Carpathians, in: Wessely, G. and Liebel, W. (Eds.): Oil and gas in Alpidic trustbelts and basin of central and eastern Europe, EAGE Spec. Publ., 5, 187195, 1996.

Smith, G. P. and Okulitch, A. V.: The Inglefield uplift: a Devonian tectonic element, Ellesmere Island, Arctic Canada, Bull. Can. Soc. Petrol. Geol., 35, 75-78, 1987.

Sobolev, S. V., Zeyen, H., Granet, M., Achauer, U., Bauer, C., Werling, F., Altherr, R., and Fuchs, K.: Upper mantle temperatures and lithosphere-asthenosphere system beneath the French Massif Central constrained by seismic, gravity, petrologic and thermal observations, Tectonophysics, 275, 143-163, 1997.

Sobornov, K. O. and Tarasov, P. P.: Structure and new targets for petroleum exploration in the Polar Urals thrust-and-fold belt, in: Roure, F., Ellouz, N., Shein, V. S., and Skvortsov, I. (Eds.): Geodynamic evolution of sedimentary basins, Institut Français du Pétrole and Ed. Technip, Paris, 235-253, 1994.

Sovchik, Yu. V. and Vul, M. A.: New data on the structure and hydrocarbon prospects of the Ukrainian Carpathians and their foreland, in: Ziegler, P. A. and Horvàth, F. (Eds.): Structure and Prospects of Alpine Basins and Forelands. Peri-Tethys Mem., 2. Mém. Mus. natn. Hist. nat., Paris, 170, 391-401, 1996.

Stampfli, G. M.: Le Briançonnais, terrain exotique dans les Alpes? Eclog. Geol. Helv., 86, 1-45, 1993.

Stampfli, G. M.: Intra-Alpine terrane: a Palaeotethyan remnant in the Alpine Variscides, Eclog. Geol. Helv., 89, 13-42, 1996.

Stampfli, G. M. and Marchant, R. H.: Geodynamic evolution of the Tethyan margins of the Western Alps, in: Pfiffner, O. A., Lehner, P., Heitzmann, P. Z., Müller, St., and Steck, A. (Eds.): Deep structure of the Swiss Alps, Birkhäuser A.G., Basel, 223-239, 1997.

Stampfli, G. M., Mosar, J., Marquer, D., Marchant, R., Baudin, T., and Borel, G.: Subduction and obduction processes in the Swiss Alps, Tectonophysics, 296, 159-204, 1998.

Stampfli, G. M., Mosar, J., Favre, P., Pillevuit, A., and Vannay J.-C.: Permo-Mesozoic evolution of the western Tethys realm: the NeoTethys East-Mediterranean Basin connection, in: Ziegler, P. A., Cavazza, W., Robertson, A. H. F., and Crasquin-Soleau, S. (Eds.): PeriTethyan Rift/Wrench Basins and Passive Margins, Peri-Tethys Mem., 6. Mém. Mus. natn. Hist. nat., Paris, 186, 51$108,2001$.

Stefanescu, M. and Baltes, N.: Do hydrocarbon prospects still exist in the East-Carpathian Cretaceous flysch nappes?, in: Ziegler, P. A. and Horvàth, F. (Eds.): Structure and Prospects of Alpine Basins and Forelands, Peri-Tethys Mem., 2. Mém. Mus. natn. Hist. nat., Paris, 170, 427-438, 1996.

Steininger, F., Bernor, R. L., and Fahlbusch, V.: European Neogene marine/continental chrologic correlation, in: Lindsay E. H., Fahlbusch, V., and Mein, P. (Ed.): European Neogene Mammal Chronology, Plenum Press, New York, NATO ASI Ser. A, 180, 15-46, 1989.

Stephens, M. B. and Gee, D. G.: A tectonic model for the evolution of the eugeosynclinal terranes in the central Scandinavian Caledonides, in: Gee, D. G. and Sturt, B. A. (Eds.): The Caledonian Orogen - Scadinavia and related areas. John Wiley and Sons, 953-978, 1985.

Stevenson, G. M. and Baars, D. L.: The Paradox: a pull-apart basin of Pennsylvanian age, in: Peterson, J. E. (Ed.): Paleotectonics and sedimentation in the Rocky Mountain Region, United States, Am. Assoc. Petrol. Geol. Mem., 41, 513-539, 1986.

Stockmal, G. S. and Beaumont, C.: Geodynamic models of convergent margin tectonics: the southern Canadian Cordillera and the Swiss Alps, in: Beaumont, C. and Tankard, T. (Eds.): Sedimentary basins and basin-forming mechanisms, Can. Soc. Petrol. Geol. Mem., 12, 393-411, 1987.

Stockmal, G. S., Beaumont, C., and Boutillier, R.: Geodynamic models of convergent margin tectonics: transition from rifted margin to overthrust belt and consequences for foreland-basin development, Am. Assoc. Petrol. Geol. Bull., 70, 181-190, 1986.

Stockmal, G. S., Cant, D. J., and Bell, J. S.: Relationship of stratigraphy of the Western Canada foreland basin to Cordilleran tectonics: insight from geodynamic models, in: Macqueen, R. W. and Leckie, D. A. (Eds.): Foreland basins and fold belts, Am. Assoc. Petrol. Geol. Mem., 55, 107-124, 1992.

Straume, A. K. and Austrheim, H.: Importance of fracturing during retro- metamorphism of eclogites, J. Metamorphic Geol., 7, 637652, 1999.

Tankard, A. J.: Depositional response to foreland deformation in the Carboniferous of Eastern Kentucky, Am. Assoc. Petrol. Geol. Bull., 70, 853-868, 1986.

Tari, G.: Neoalpine tectonics of the Danube Basin (NW Pannonian Basin, Hungary), in: Ziegler, P. A. and Horvàth, F. (Eds.): Structure and Prospects of Alpine Basins and Forelands, Peri-Tethys Mem., 2. Mém. Mus. natn. Hist. nat., Paris, 170, 439-454, 1996.

Torsvik, T. H.: Palaeozoic palaeogeography: a North Atlantic viewpoint, GFF, 120, 109-118, 1998.

Turcotte, D. L., McAdoo, D. C., and Caldwell, J. G.: An elastic- 
perfectly plastic analysis of the bending of the lithosphere at a trench, Tectonophysics, 47, 193-205, 1978.

Turner, J. P.: Switches in subduction direction, and the lateral termination of mountain belts; Pyrenees-Cantabrian transition, Spain, J. Geol. Soc., London, 153, 563-571, 1996.

Van der Pluijm, B. A., Craddock, J. P., Graham, B. R., and Harris, J. H.: Paleostress in cratonic North America: implications for deformation of continental interiors, Science, 277, 794-796, 1997.

Van Wees, J.-D. and Cloetingh, S.: 3D flexure and intraplate compression in the North Sea Basin, Tectonophysics, 266, 343-359, 1996.

Velaj, T., Davison, I., Serjani, A., and Alsop, I.: Thrust tectonics and the role of evaporites in the Ionian zone of the Albanides, Am. Assoc. Petrol. Geol. Bull., 83, 1408-1425, 1999.

Vera, J. A.: Evolution of the South Iberian continental margin, in: Ziegler, P. A., Cavazza, W., Robertson, A. H. F., and CrasquinSoleau, S. (Eds.): PeriTethyan Rift/Wrench Basins and Passive Margins, Peri-Tethys Mem., 6. Mém. Mus. natn. Hist. nat., Paris, 186, 109-143, 2001.

Vergés, J. and Sabat, F.: Constraints on the Neogene Mediterranean kinematic evolution along a $1000 \mathrm{~km}$ transect from Iberia to Africa, in: Durand, B., Jolivet, L., Horvàth, F., and Séranne, F. (Eds.): The Mediterranean Basin: Tertiary Extension within the Alpine Orogen, Geol. Soc., London, Spec. Publ., 156, 63-80, 1999.

Vergés, J. and García-Senez, J.: Mesozoic evolution and Cenozoic inversion of the Pyrenean rift, in: Ziegler, P. A., Cavazza, W., Robertson, A. H. F., and Crasquin-Soleau, S. (Eds.): PeriTethyan Rift/Wrench Basins and Passive Margins, Peri-Tethys Mem., 6. Mém. Mus. natn. Hist. nat., Paris, 186, 187-212, 2001.

Vergés, J., Marzo, M., Santaeulària, T., Serra-Kiel, J., Burbank, D. W., Muñoz, J. A., and Giménez-Montsant, J.: Quantified vertical motions and tectonic evolution of the SE Pyrenean foreland basin, in: Mascle, A., Puigdefàbregas, C., Luterbacher, H. P., and Fernandez, M. (Eds.): Cenozoic Foreland Basins of Western Europe, Geol. Soc., London, Spec. Publ., 134, 107-134, 1998.

Vially, R., Letouzey, J., Bénard, F., Haddadi, N., Desforges, G., Askri, H., and Boudjema, A.: Basin inversion along the North African margin: the Sahara Atlas (Algeria), in: Roure, F. (Ed.): Peri-Tethyan platforms, Edition Technip, Paris, 79-118, 1994.

Von Huene, R. and Lee, H.: The possible significance of pore fluid pressure in subduction zones, in: Watkins, J. S. and Drake, C. L. (Eds.): Studies in Continental Margin Geology, Am. Assoc. Petrol. Geol. Mem., 34, 781-791, 1982.

Von Huene, R. and Scholl, D. W.: Observations at convergent margins concerning sediment subduction, subduction erosion, and the growth of continental crust, Rev. Geophys., 29, 279-316, 1991.

Von Huene, R. and Scholl, D. W.: The return of sialic material to the mantle indicated by terrigenous material subducted at convergent margins, Tectonophysics, 219, 163-175, 1993.

Von Huene, R., Reston, T., Kukowski, N., Dehghani, G. A., Weinreb, W., and IMERSE Working Group: A subducting seamount beneath the Mediterranean Ridge, Tectonophysics, 271, 249261, 1997.

Wagner, L. R.: Stratigraphy and hydrocarbons in the upper Austrian Molasse Foredeep (active margin), in: Wessely, G. and Liebel, W. (Eds.): Oil and Gas in Alpidic trustbelts and basin of central and eastern Europe, EAGE Spec. Publ., 5, 217-235, 1996.

Wagner, L. R.: Tectono-stratigraphy and hydrocarbons in the Molasse Foredeep of Salzburg, upper and lower Austria, in: Mas- cle, A., Puigdefàbregas, C., Luterbacher, H. P., and Fernandez, M. (Eds.): Cenozoic Foreland Basins of Western Europe, Geol. Soc., London, Spec. Publ., 134, 339-369, 1998.

Walley, C. D.: The Lebanon passive margin and the evolution of the Levantine Neotethys, in: Ziegler, P. A., Cavazza, W. Robertson, A. H. F., and Crasquin-Soleau, S. (Eds.): PeriTethyan Rift/Wrench Basins and Passive Margins, Peri-Tethys Mem., 6. Mém. Mus. natn. Hist. nat., Paris, 186, 407-439, 2001.

Waschbusch, P. J. and Royden, L. H.: Spatial and temporal evolution of a foredeep basin: Lateral strength variations and inelastic yielding in continental lithosphere, Basin Res., 4, 179-196, 1992.

Willet, S., Beaumont, C., and Fullsack, Ph.: Mechanical models for the tectonics of doubly vergent compressional orogens, Geology, 21, 371-374, 1993.

Wilson, M. and Biancini, G.: Tertiary-Quaternary magmatism within the Mediterranean and surrounding regions, in: Durand, B., Jolivet, L., Horvàth, F. and Séranne, F. (Eds.): The Mediterranean Basin: Tertiary extension within the Alpine Orogen, Geol. Soc., London, Spec. Publ., 156, 141-168, 1999.

Wong A Ton, S. Y. M. and Wortel, M. J. R.: Slab detachment in continental collision zones: an analysis of controlling parameters, Geophys. Res. Lett., 24, 2095-2098, 1997.

Wortel, M. J. R. and Spakman, W.: Structure and dynamics of subducted lithosphere in the mediterranean region, Proc. Kon. NEd. Acad. Wetensch., 95, 325-347, 1992.

Ye, H., Royden, L., Burchfiel, C., and Schuepbach, M.: Late Paleozoic deformation of interior North America: the greater Ancestral Rocky Mountains, Am. Assoc. Petrol. Geol. Bull., 80, 13971432, 1996.

Yilmaz, Y.: New evidence and model in the evolution of the southeast Anatolian orogen, Geol. Soc. Am. Bull., 15, 251-271, 1993.

Zeck, H. P.: Alpine plate tectonics in the western Mediterranean: a westward- directed subduction regime followed by slab roll-back and slab detachment, in: Durand, B., Jolivet, L., Horvàth, F., and Séranne, F. (Eds.): The Mediterranean Basin: Tertiary Extension within the Alpine Orogen, Geol. Soc., London, Spec. Publ., 156, 109-120, 1999.

Zhang, G.-B. and Bott, M. H. P.: Modelling the evolution of asymmetric basins bounded by high-angle reverse faults with application to foreland basins, Tectonophysics, 322, 203-218, 2000.

Ziegler, P. A.: The development of sedimentary basins in western and Arctic Canada, Alberta Soc. Petrol. Geol., 89 p, 1969.

Ziegler, P. A.: Evolution of the Arctic-North Atlantic and western Tethys, Am. Assoc. Petrol. Geol. Mem., 43, 198 p, 1988.

Ziegler, P. A.: Evolution of Laurussia. A study in Late Palaeozoic plate tectonics, Kluwer Acad. Publ., Dordrecht, 102 p, 1989.

Ziegler, P. A.: Geological Atlas of Western and Central Europe, 2nd Ed. Shell Internationale Petroleum Mij. B.V. and Geol. Soc., London, 239 p, 1990.

Ziegler, P. A.: Plate-moving mechanisms: their relative importance, J. Geol. Soc., London, 150, 927-940, 1993.

Ziegler, P. A.: Cenozoic rift system of western and central Europe: an overview, Geol. Mijnbow, 73, 99-127, 1994.

Ziegler, P. A.: Geodynamic processes governing development of rifted basins, in: Roure, F., Ellouz, N., Shein, V. S., and Skvortsov, I. (Eds.): Geodynamic evolution of sedimentary basins, Institut Français du Pétrole and Ed. Technip, Paris, 1967, 1996.

Ziegler, P. A. and Roure, F.: Architecture and petroleum systems of the Alpine Orogen and associated basins, in: Ziegler, P. A.: and Horvàth, F. (Eds.): Structure and Prospects of Alpine Basins 
and Forelands, Peri-Tethys Mem., 2. Mém. Mus. natn. Hist. nat., Paris, 170, 15-45, 1996.

Ziegler, P. A. and Stampfli, G. M.: Late Palaeozoic-Early Mesozoic plate boundary reorganization: collapse of the Variscan orogen and opening of Neotethys, in: Cassinis, G. (Ed.): The continental Permian of the Southern Alps and Sardinia (Italy). Regional Reports and General Correlation, Natura Bresciana, Ann. Mem., Mus. Civ. Sc. Nat., Brescia, Monografia, 25, 1-19, 2001.

Ziegler, P. A., Cloetingh, S., and Van Wees, J.-D.: Dynamics of intra-plate compressional deformation: the Alpine foreland and other examples, Tectonophysics, 252, 7-59, 1995.

Ziegler, P. A., Schmid, S. M., Pfiffner, A., and Schönborn, G.: Structure and evolution of the Central Alps and their northern and southern foreland basins, in: Ziegler, P. A.: and Horvàth, F. (Eds.): Structure and Prospects of Alpine Basins and Forelands, Peri-Tethys Mem., 2. Mém. Mus. natn. Hist. nat., Paris, 170, 211-233, 1996.
Ziegler, P. A., Van Wees, J.-D., and Cloetingh, S.: Mechanical controls on collision-related compressional intraplate deformation, Tectonophysics, 300, 103-129, 1998.

Zimmer, W. and Wessely, G.: Hydrocarbon exploration in the Austrian Alps, in: Ziegler, P. A. and Horvàth, F. (Eds.): Structure and Prospects of Alpine Basins and Forelands, Peri-Tethys Mem., 2. Mém. Mus. natn. Hist. nat., Paris, 170, 285-304, 1996.

Zizi, M.: Triassic-Jurassic extension and Alpine inversion in northern Morocco, in: Ziegler, P. A. and Horvàth, F. (Eds.): Structure and Prospects of Alpine Basins and Forelands, Peri-Tethys Mem., 2. Mém. Mus. natn. Hist. nat., Paris, 170, 87-101, 1996.

Zoetemeijer, R., Tomek, C., and Cloetingh, S.: Flexural expression of European continental lithosphere under the western outer Carpathians, Tectonics, 18, 843-861, 1999.

Zonenshain, L. P., Kuzmin, M. I, and Natapov, L. M.: Geology of the USSR: a plate tectonic synthesis, Am. Geophys. Union, Geodynamic Series, 21, 242 p., 1990. 